UNIVERSIDADE DE SÃO PAULO

FACULDADE DE MEDICINA DE RIBEIRÃO PRETO

MARCELA DE ALENCAR COELHO NETO

\title{
Útero em forma de "T": definição, critérios diagnósticos, prevalência, implicações clínicas e tratamento
}

RIBEIRÃO PRETO 


\section{Útero em forma de "T": definição, critérios diagnósticos, prevalência, implicações clínicas e tratamento}

Tese apresentada à Faculdade de Medicina de Ribeirão Preto da Universidade de São Paulo para obtenção do título de Doutor em Ciências.

Área de Concentração: Ginecologia e Obstetrícia.

Orientador: Prof. Dr. Wellington de Paula Martins 
Autorizo a reprodução e divulgação total ou parcial desta dissertação, por qualquer meio convencional ou eletrônico, para fins de estudo e pesquisa, desde que citada a fonte.

FICHA CATALOGRÁFICA

Coelho Neto, Marcela de Alencar

Útero em forma de "T": definição, critérios diagnósticos, prevalência, implicações clínicas e tratamento. / Marcela de Alencar Coelho Neto; Orientador, Wellington de Paula Martins. Ribeirão Preto, 2020.

137p.: 13 il. $30 \mathrm{~cm}$

Tese (Doutorado) - Programa de Ginecologia e Obstetrícia. Faculdade de Medicina de Ribeirão Preto da Universidade de São Paulo, Ribeirão Preto, 2020.

1. Ductos müllerianos. 2. Anormalidades do útero. 3. Útero em "T". 4. Concordância no útero dismórfico. 5. Endentação lateral. 6. Dietilestilbestrol. 
Auno: Marcela de Alencar Coelho Neto

Título: Útero em forma de "T": definição, critérios diagnósticos, prevalência, implicações clínicas e tratamento.

Tese apresentada à Faculdade de Medicina de Ribeirão Preto da Universidade de São Paulo para obtenção do título de Doutor em Ciências.

Área de Concentração: Ginecologia e Obstetrícia.

Aprovado em:

\section{Banca Examinadora}

Prof. Dr.

Instituição:

Julgamento:

Prof. Dr

Instituição:

Julgamento

Prof. Dr.

Instituição:

Julgamento:

Prof. Dr.

Instituição:

Julgamento 


\section{Dedicatória}

À minha família, por ser apoio incondicional na minha jornada. 


\section{Agradecimentos}

A Deus, que pela intercessão de São João Paulo II, escuta minhas preces e me mantém firme, mesmo nos momentos mais difíceis.

Aos meus pais, por estarem sempre ao meu lado, por me guiarem e me apoiarem na realização dos meus sonhos.

Aos meus irmãos, por podermos andar sempre de mãos dadas na caminhada da vida.

A Gustavo, pela parceria, por nunca duvidar de que irei conseguir e por me inspirar serenidade.

Às minhas filhas, Olívia e Helena, por me motivarem persistência na concretização dos planos que realmente importam.

Ao meu orientador, Prof. Dr. Wellington de Paula Martins, por acreditar e confiar em mim, sempre me proporcionando incontáveis e inestimáveis oportunidades de aprendizado.

A Artur Ludwin, que recrutou e examinou as pacientes incluídas no estudo CUME, por ser sempre tão disponível e por me repassar tantos ensinamentos.

Aos demais coautores, por me mostrarem que a distância física não interfere na produção do conhecimento.

Aos professores da Reprodução Humana do Departamento de Ginecologia e Obstetrícia e à Faculdade de Medicina de Ribeirão Preto da Universidade de São Paulo. que me possibilitaram encontrar minha missão e amor à profissão, mudando minha trajetória para todo o sempre.

Aos amigos e familiares que, sempre presentes, torcem e comemoram minhas conquistas como se fossem suas. 


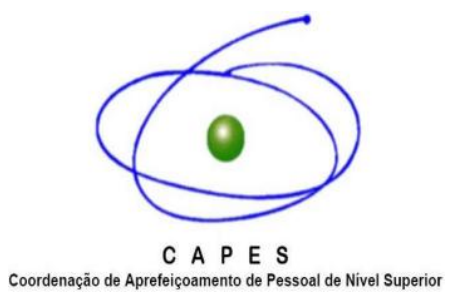

Este estudo foi realizado com recursos disponibilizados pela CAPES - Coordenação de Aperfeiçoamento de Pessoal de Nível Superior. 
Coelho Neto MA. Útero em forma de "T": definição, critérios diagnósticos, prevalência, implicações clínicas e tratamento. Tese (Doutorado) - Faculdade de Medicina de Ribeirão Preto, Universidade de São Paulo. Ribeirão Preto. 2020.

Objetivos: Avaliar se existe medida confiável e precisa para distinguir o útero em "T" do útero normal/arqueado e sumarizar a evidência disponível em relação a definições, diagnóstico, prevalência, implicações clínicas e impacto do tratamento cirúrgico para o útero em "T" não relacionado ao dietilestilbestrol (DES). Métodos: Estudo prospectivo observacional para avaliar confiabilidade/concordância com elementos de acurácia diagnóstica em uma amostra de 100 blocos de ultrassonografia tridimensional (US-3D) de úteros apresentando endentação lateral da cavidade, tendo como padrão de referência a impressão subjetiva de 15 especialistas. As medidas foram realizadas de forma independente por dois especialistas para avaliar o coeficiente de correlação de concordância (CCC), a precisão diagnóstica pela a área sob a curva (AUROC), e o melhor ponto de corte pelo índice de Youden. Para resumir a evidência disponível em relação ao útero em "T", realizou-se uma revisão sistematizada buscando estudos no PubMed, Scopus e EMBASE em mar-2020. Estudos sobre útero em "T" não relacionado ao DES incluindo 10 ou mais mulheres foram elegíveis. Resultados: No estudo de reprodutibilidade e precisão diagnóstica, foram incluídos 100 participantes (pelo padrão de referência, 20 foram julgados em "T" e 80 normais/arqueados). A concordância entre especialistas foi de $82 \%$ (kappa=0,43). As três medidas identificadas com precisão diagnóstica e seus respectivos pontos de corte foram: ângulo de endentação lateral (AUROC $=0,95) \leq 130^{\circ}$, profundidade da endentação lateral (AUROC $=0,92) \geq 7 \mathrm{~mm}$, e ângulo "T" (AUROC $=0,87) \leq 40^{\circ}$. O ângulo "T" foi a medida com melhor reprodutibilidade interobservador $(C C C=0,87)$. Sugere-se considerar útero em "T" na presença dos três critérios (valor preditivo positivo=0.93). Na revisão sistematizada, 2504 referências foram identificadas, e 20 estudos foram incluídos. Há apenas estudos de baixa qualidade. O diagnóstico do útero em " $T$ " foi, comumente, realizado por US-3D, e o critério mais citado foi o da European Society of Human Reproduction and Embryology and the European Society for Gynecological Endoscopy (ESHRE-ESGE). A prevalência do útero em "T" variou de $0,2-10 \%$. Sua etiologia foi relacionada à adenomiose, sinéquias e como sendo uma condição primária. Resultados reprodutivos ruins foram relacionados ao útero em "T" (infertilidade, aborto, parto pré-termo, gravidez ectópica e falha de implantação). Os benefícios do tratamento cirúrgico por metroplastia histeroscópica foram analisados em 12 estudos, que mencionaram melhora nas taxas de gravidez, nascidos vivos, parto a termo, redução de abortamento e gravidez ectópica (evidência de muito baixa qualidade). Conclusões: A concordância entre especialistas para o diagnóstico do útero em "T" foi moderada. Três medidas tiveram boa acurácia diagnóstica e confiabilidade razoável a moderada. Até o momento, prevalência, importância clínica e impacto da cirurgia nos resultados reprodutivos de mulheres com útero em "T" são desconhecidos. Alguns estudos relatam melhora nos resultados reprodutivos após a cirurgia, mas a evidência é de muito baixa qualidade. A definição proposta pelo CUME para útero em "T" poderá ajudar no desenvolvimento de ensaios clínicos randomizados e ser adotada pelas diretrizes no estudo das malformações uterinas.

Palavras-chave: Ductos müllerianos. Anormalidades do útero. Útero em "T". Concordância no útero dismórfico. Endentação lateral. Dietilestilbestrol. 
Abstract 
Coelho Neto MA. T-shaped uterus: T-shaped uterus: definition, diagnostic criteria, prevalence, clinical implications, and treatment. Tese (Doutorado) Faculdade de Medicina de Ribeirão Preto, Universidade de São Paulo. Ribeirão Preto. 2020.

Objectives: To assess whether is there any uterine measurement that is reliable to distinguish between T-shaped and normal/arcuate uterus and to summarize the current evidence regarding definitions, diagnosis, prevalence, clinical implications and impact of surgical treatment for T-shaped uterus not related to Diethystilbestrol (DES) exposure. Methods: A prospectively designed multi-rater reliability/agreement study with elements of diagnostic accuracy study was performed in a sample of 100 three-dimensional (3D) datasets of uteri presenting lateral uterine cavity indentation, using as reference standard the subjective impression of fifteen blinded experts. The measurements were independently performed by two blinded experienced observers to evaluate the concordance correlation coefficient (CCC), the diagnostic test accuracy by the area under ROC curve (AUROC) and the best cut-off value by using Youden's index. To summarize the available evidence regarding T-shaped uterus, we have performed a systematic review searching on PubMed, Scopus and EMBASE on Mar-2020. All studies presenting any data regarding T-shaped uterus not related to DES exposure including at least 10 women were eligible. Results: In the reliability and accuracy study, we have included 100 participants $(20 \mathrm{~T}$-shaped uteri and 80 normal/arcuate in the reference standard). The agreement among experts was $82 \%$ (kappa $=0.43)$. Three measurements with good diagnostic test accuracy were identified and their respective cut-offs were: lateral indentation angle (AUROC $=0.95$ ) $\leq 130^{\circ}$, lateral indentation depth (AUROC $\left.=0.92\right) \geq 7 \mathrm{~mm}$, and T-angle (AUROC=0.87) $\leq 40^{\circ}$. T-angle was the one with the best inter-observer reproducibility $(C C C=0.87)$. We suggest considering as T-shaped uterus when meeting all the three criteria (positive predictive value=93). In the systematic review, 2,504 records were found, and 20 studies were included. There are only poor-quality studies. The diagnosis of T-shaped uterus was most based in three-dimensional US (3D-US) and the most cited was the criteria from European Society of Human Reproduction and Embryology and the European Society for Gynecological Endoscopy (ESHRE/ESGE). The prevalence of T-shaped uterus varied from $0.2-10 \%$. The etiology of T-shaped uterus was assigned to adenomyosis, adhesions and as a primary condition. Worse reproductive outcomes were related to $\mathrm{T}$-shaped uterus (infertility, miscarriage, preterm delivery, ectopic pregnancy, and repeated implantation failure). The benefits of surgical treatment by hysteroscopic metroplasty were analyzed by 12 studies, which had mentioned improvement on pregnancy, live birth and term delivery rates, reduction in miscarriage and ectopic pregnancy (evidence of very low quality). Conclusions: The agreement among top-experts for diagnosing T-shaped uterus was moderate. Three measurements had good diagnostic test accuracy and fair to moderate reliability. Until now, prevalence, clinical relevance, and impact of surgery on reproductive outcomes in women with T-shaped uterus are unknown. Some studies report improvement on reproductive outcomes after surgery, but the evidence is of very low quality. The CUME definition of $\mathrm{T}$ shaped uterus may help with the development of interventional randomized controlled trials and therefore could be adopted by guidelines on uterine anomalies.

Keywords: Mullerian ducts. Congenital uterine anomalies. T-shaped uterus. Dysmorphic uterus agreement. Lateral indentation. Diethylstilbestrol. 
Lista de Figuras 
Artigo 1: Congenital Uterine Malformation by Experts (CUME): T-shaped uterus

Figura 1 - Três tipos básicos de cavidade uterina normal de acordo com a experiência da histerossalpingografia

Figura 2 - Imagens da apresentação enviadas para os especialistas em duas modalidades de ultrassonografia tridimensional

Figura 3 - Demonstração das quinze medidas testadas para reconhecimento do útero em "T".

Figura 4 - Gráficos de Bland-Altman para a diferença absoluta e relativa observadas entre as medições dos dois especialistas

Figura 5 - Nomograma de Fagan para determinar a probabilidade de uma mulher ter útero em "T" baseada nos critérios propostos por este estudo e na opção mais votada pelos especialistas ..............................36

Figura 6 - Útero em "T" de acordo com o CUME 38

Figura 7 - Exemplos de como realizar as três medidas propostas para definição do útero em "T" usando o modo US-3D Omniview com $\mathrm{VCl}$ (imagem de contraste de volume)

Figura 8 - Exemplos de úteros com o diagnóstico feito com mais frequência pelos especialistas e reconhecimento do útero normal e útero em "T" com muito boa (12-15/15 votos) e boa (8-11/15 votos) concordância com número descrescente de votos para o útero noral do topo à base

Figura Supl. 1- Como realizar as três medidas para o diagnóstico do útero em forma de " $T$ " em variantes de úteros com endentação lateral

Artigo 2: Definitions, prevalence, clinical implications and treatment of Tshaped uterus: systematic review

Figura 1 - Fluxograma da seleção dos estudos

Figura 2 - Histerossalpingografia de um útero com as tubas pérvias, cuja cavidade lembra a letra "T"

Figura 3 - Visão coronal do útero nos modos renderizados curvos de Ultrassom transvaginal tridimensional (linha superior: HDlive; linha inferior: Omniview com imagem de contraste de volume)

Figura 4 - Visão coronal do útero usando ultrassonografia tridimensional (3D), histerossonografia 3D com o modo renderizado HDlive, histerossonografia 3D com $\mathrm{VCl}$ e histerossongrafia 3D com SonoAVC. 


\section{Artigo 1: Congenital Uterine Malformation by Experts (CUME): T-shaped uterus}

Tabela 1 - Descrição das quinze medidas testadas para diferenciar o útero em "T" do útero normal/arqueado.

Tabela 2 - Diagnóstico do útero em "T" pelo julgamento subjetivo dos 15 especialistas e de acordo com a área de conhecimento

Tabela 3 - Concordância entre especialistas em reconhecer o útero em "T" pelo julgamento subjetivo da visão coronal do útero por ultrassonografia tridimensional

Tabela 4 - Confiabilidade/concordância inter-observador das três medidas mais precisas selecionadas entre medidas potencialmente úteis para estabelecer critérios objetivos de diagnóstico para o útero em forma de "T".

Tabela 5 - Precisão diagnóstica das três medidas mais precisas selecionadas dentre as 15 medidas potencialmente úteis para estabelecer critérios diagnósticos objetivos para o útero em "T"

Tabela 6 - Medidas de precisão diagnóstica e concordância expressas por kappa para diagnóstico feito por cada especialista, ou pelas combinações dos três critérios diagnósticos em relação à opção mais votada dentre os 15 especialistas (padrão de referência CUME)

Tabela 7 - Critérios e definições propostos pelo CUME para a classificação da morfologia uterina como normal/arqueada, útero em "T" borderline e útero em "T" pelo CUME

Tabela Supl. 1 - Detalhes dos especialistas do grupo CUME para útero em "T" e avaliadores que realizaram as medidas para estabelecer critérios diagnósticos objetivos para o útero em "T".

Tabela Supl. 2 - Resultados de todas as medidas testadas pelos observadores 1 e 2

Tabela Supl. 3 - Confiabilidade/concordância interobservador de todas as medidas potencialmente úteis testadas para estabelecer critérios diagnósticos objetivos para o útero em " $\mathrm{T}$ "

Tabela Supl. 4 - Precisão diagnóstica de todas as medidas potencialmente úteis testadas para estabelecer critérios diagnósticos objetivos para o útero em "T". 
Tabela Supl. 5 - Útero em "T" de acordo com os melhores pontos de corte para as medidas selecionadas e sua concordância com a opinião dos especialistas (padrão de referência).

Artigo 2- Definitions, prevalence, clinical implications and treatment of Tshaped uterus: systematic review

Tabela 1 - $\quad$ Critérios diagnósticos usados pelos estudos incluídos .................82

Tabela 2 - $\quad$ Prevalência do útero em "T" relatada nos estudos incluídos ........86

Tabela 3 - $\quad$ Associações/causas relacionadas ao útero em "T" $\quad$......................88

Tabela 4 - $\quad$ Associação do útero em "T" com condições clínicas ......................88

Tabela 5 - $\quad$ Estudos avaliando os efeitos das intervenções para útero em

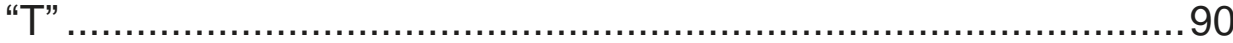

Tabela 6 - $\quad$ Sumário de conclusões dos estudos avaliando metroplastia histeroscópica para melhorar resultados reprodutivos em mulheres com útero em "T" .......................................................93

Tabela 7 - $\quad$ Estudos elegíveis que não forneceram dados para análise..........94

Tabela Supl. 1 - Qualidade dos estudos observacionais incluídos de acordo com a Escala Newcastle-Otawwa (NOS)....................................95

Tabela Supl. 2 - Julgamento dos estudos de acurácia diagnóstica de acordo

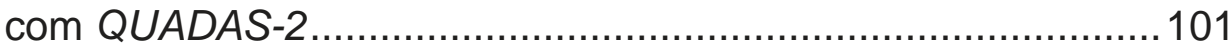

Tabela Supl. 3 - Julgamento dos estudos de confiabilidade / concordância de acordo com o Quality Appraisal of Diagnostic Reliability (QAREL) 


\section{Lista de Abreviaturas}


AFS-

American Fertility Society

ASRM-

American Society for Reproductive Medicine

CUME-

Malformações uterinas congênitas por especialistas

DES-

Dietilestilbestrol

ECR-

Ensaio clínico randomizado

ESHRE-ESGE- $\quad$ European Society of Human Reproduction and EmbryologyEuropean Society for Gynecological Endoscopy

US-3D- $\quad$ Ultrassonografia tridimensional 


\section{SUMÁRIO}

1. INTRODUÇÃO

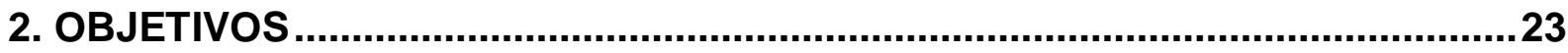

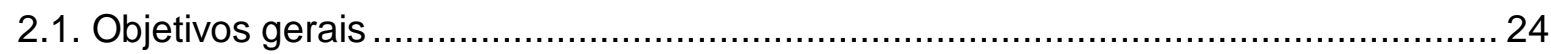

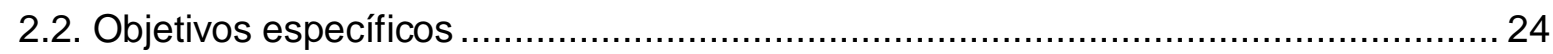

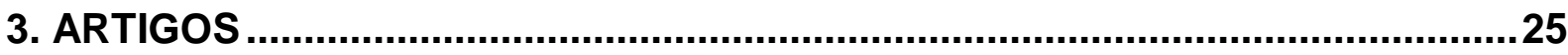

3.1. Artigo 1: Congenital Uterine Malformation by Experts (CUME): T-shaped uterus...... 26

3.2. Artigo 2: Definitions, prevalence, clinical implications and treatment of T-shaped uterus: systematic review.

4. DISCUSSÃO

5. CONCLUSÃO

6. REFERÊNCIAS BIBLIOGRÁFICAS.

7. ANEXOS 
1- Introdução 
O útero em "T" é uma malformação uterina congênita consequente à falha no desenvolvimento tardio do útero (útero hipoplásico, útero em "T" e exposição ao dietilestilbestrol (DES) (1). O útero em "T" exibe endentação lateral com estreitamento importante da cavidade uterina nas paredes laterais (2), o que faz com que o formato da cavidade endometrial lembre a letra "T" (3).

O útero em "T" foi primeiramente mencionado por Kauffman et al. (4), por Buttran e Gibbons (5) e pela American Fertility Society (AFS) (agora denominada American Society for Reproductive Medicine - ASRM) (6), como um defeito relacionado à exposição ao DES, sem menção de critérios para definir esta condição (defeitos do tipo VII ou relacionados ao DES). Em 2013, a European Society of Human Reproduction and Embryology e a European Society for Gynecological Endoscopy (ESHRE-ESGE) propuseram uma definição para útero em "T" que consiste na presença de cavidade uterina estreita devido ao espessamento das paredes laterais com correlação $2 / 3$ do corpo uterino e 1/3 do colo do útero (2), na qual não são mencionados critérios objetivos para diagnosticar o útero em forma de "T" e nem como as medidas do útero seriam realizadas.

Em 2016, o ESHRE-ESGE propôs um consenso atualizado sobre o diagnóstico de malformações uterinas (7). Sugere-se que em uma imagem de US3D (ultrassonografia tridimensional) renderizada, as medidas sejam realizadas no plano médio-coronal do útero. O US-3D, além de ser uma técnica não invasiva, bem tolerada pelas pacientes e ter baixo custo $(8,9)$, permite a visualização do plano coronal do útero, criado por reconstrução volumétrica, possibilitando visão frontal do útero, detalhes da cavidade uterina e contorno externo do útero (9). Os blocos de US-3D podem ser armazenados para análise off-line posterior (10). Sugere-se medir a espessura da parede uterina como a distância entre a linha que conecta os dois óstios tubários e o contorno uterino externo em casos de pacientes com superfície uterina externa normal. A espessura da parede lateral é estimada medindo-a no ângulo de $90^{\circ}$ em relação ao revestimento da junção endometrial-miometrial (7). Não são mencionados valores absolutos a serem usados para identificar úteros em forma de "T".

A ASRM também desenvolveu um novo protocolo em 2016 (11), em que é reconhecida a importância de se diferenciar o útero septado do útero arqueado; 
porém nada menciona em relação ao útero em forma de "T". De acordo com esta diretriz, um número considerável de úteros permanece sem classificação, e pacientes permanecem não diagnosticadas.

O primeiro estudo CUME (malformações uterinas congênitas por especialistas) (12) foi publicado com o objetivo de avaliar o nível de concordância entre os especialistas em distinguir entre útero septado e útero normal/arqueado aplicando avaliação subjetiva de imagens no plano coronal do útero por meio de US3D. Além disso, forneceu critérios mais precisos para diferenciar o útero septado do útero normal/arqueado. Embora essa classificação tenha alcançado melhor entendimento na diferenciação do útero normal/arqueado em relação ao septado, ela não menciona o útero em forma de "T".

O útero em forma de "T" é comumente relacionado à exposição in utero ao DES $(6,13)$, um medicamento prescrito para gestantes em diferentes países para evitar abortos até a década de 1980 (14). As últimas dentre as 1-1,5 milhão de mulheres expostas ao DES intraútero não estão mais em idade reprodutiva $(15,16)$, mas o útero em "T" continua a ser identificado em mulheres jovens $(3,17)$. A patogênese do útero em forma de "T" não é clara, e a etiologia, em muitos casos, é desconhecida $(3,13)$. O útero em "T" também pode ser de origem primária (18-20), decorrer de aderências na síndrome de Asherman $(3,13,18,20,21)$ ou adenomiose (22). Seu diagnóstico deve se basear, exclusivamente, na forma da cavidade uterina por técnicas de imagem, sem vincular o diagnóstico a uma etiologia identificada (como ocorreu na classificação da AFS, que relacionava útero em "T" ao DES) (6).

A prevalência de defeitos uterinos na população geral/fértil é de aproximadamente $7 \%$ (23). No entanto, mulheres que apresentam malformações uterinas podem ter maior comprometimento da saúde reprodutiva (7). Os defeitos uterinos podem ser encontrados em $8 \%$ das mulheres inférteis, $13 \%$ daquelas que sofrem abortos recorrentes e $24 \%$ das que apresentam as duas condições (24). A prevalência do útero em forma de "T" não é conhecida (24), por não haver consenso sobre sua definição, nem uniformidade nos métodos empregados para diagnósticos nos estudos realizados até o momento (25), além da subjetividade na definição do ESHRE/ESGE (2), a mais utilizada. Ademais, os estudos disponíveis até o momento sobre o útero em "T" incluem apenas mulheres com antecedentes de resultados 
reprodutivos ruins: infertilidade $(13,26,27)$, abortamento $(20,21,26-28)$, aborto de repetição $(20,21,26-28)$, parto pré-termo $(29,30)$, falha de implantação $(20,21,27$ 29,31 ) e gravidez ectópica (29). Não há dados referentes a desfechos reprodutivos do útero em "T" na população geral; não se sabe, portanto, quantas mulheres conseguem alcançar gravidez bem-sucedida apesar de ter útero em "T", pois elas não chegam aos serviços de medicina reprodutiva.

O recente interesse pelo útero em "T", e o crescente número de estudos sugerindo melhora nos resultados reprodutivos de mulheres com útero em "T" após metroplastia histeroscópica $(3,13,32-35)$ podem ser decorrentes do aumento do diagnóstico dessa condição devido à definição proposta pelo ESHRE-ESGE de anomalias uterinas congênitas $(36,37)$, com o risco de operar pacientes com útero normal $(25,38)$. Não existe evidência robusta para oferecer o tratamento cirúrgico na prática clínica (25). Estudos randomizados com grupo controle de pacientes não tratadas são necessários para se avaliar melhor a eficácia da intervenção cirúrgica nos desfechos reprodutivos $(3,32,34)$.

O principal desafio no estudo do útero em " $T$ " é a ausência de critérios mensuráveis, e isto é uma barreira importante na construção de evidência em relação a prevalência, implicações clínicas e manejo desta condição. Apenas com critérios diagnósticos objetivos e mensuráveis será possível investigar se mulheres com útero em "T" obtêm piores desfechos reprodutivos e, então, avaliar a necessidade de realização de ensaios clínicos controlados para investigar o benefício do tratamento cirúrgico desta condição nos desfechos reprodutivos. 
2. Objetivos 


\subsection{Objetivos gerais}

Avaliar se existem critérios diagnósticos mensuráveis confiáveis e precisos para distinguir o útero em forma de "T" do útero normal/arqueado, tomando como referência o diagnóstico feito, com mais frequência, por múltiplos especialistas (por meio de imagens de US-3D no plano coronal), e sumarizar a evidência disponível para o útero em forma de "T" não relacionado à exposição ao DES sobre definições, diagnóstico, prevalência, implicações clínicas e impacto do tratamento cirúrgico nos desfechos reprodutivos.

\subsection{Objetivos específicos}

- Avaliar a confiabilidade/concordância interobservador de medidas e estabelecer critérios diagnósticos objetivos para o útero em "T", além de distinguir o útero em "T" do útero normal/arqueado.

- Analisar a precisão diagnóstica e os melhores pontos de corte para as medidas propostas.

- Definir o útero em "T" utlizando critérios mensuráveis objetivos, precisos e confiáveis.

- Identificar o método diagnóstico mais citado nos estudos sobre útero em "T".

- Avaliar o critério diagnóstico mais comumente utilizado no estudo do útero em "T".

- Estimar a prevalência do útero em forma de "T".

- Listar possíveis etiologias relacionadas ao útero em "T" não associadas à exposição ao DES.

- Compreender as implicações clínicas do útero em "T" nos desfechos reprodutivos.

- Analisar a evidência disponível sobre o tratamento cirúrgico do útero em forma de "T". 
3. Artigos 
Artigo 1: Congenital Uterine Malformation by Experts (CUME): T-shaped uterus 


\title{
Congenital Uterine Malformation by Experts (CUME): diagnostic criteria for T-shaped uterus
}

\author{
A. LUDWIN ${ }^{1,2} \odot$, M. A. COELHO NETO ${ }^{3,4}$, I. LUDWIN ${ }^{1,2}$, C. O. NASTRI ${ }^{3}$, W. COSTA ${ }^{3,4}$,

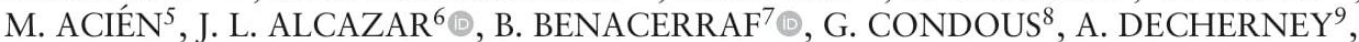 \\ R.-L. DE WILDE ${ }^{10}$, M. P. DIAMOND ${ }^{11}$, M. H. EMANUEL ${ }^{12,13}$, S. GUERRIERO ${ }^{14} \odot$, W. HURD ${ }^{15}$, \\ D. LEVINE ${ }^{16}$, S. LINDHEIM ${ }^{17}$, A. PELLICER ${ }^{18}$, F. PETRAGLIA ${ }^{19}$, E. SARIDOGAN ${ }^{20}$ and \\ W. P. MARTINS 3,4
}

${ }^{1}$ Department of Gynecology and Oncology, Jagiellonian University, Krakow, Poland; ${ }^{2}$ Ludwin $\mho$ Ludwin Gynecology, Private Medical Center, Krakow, Poland; ${ }^{3}$ SEMEAR Fertilidade, Reproductive Medicine, Ribeirão Preto, Brazil; ${ }^{4}$ Department of Obstetrics and Gynaecology, Faculty of Medicine of Ribeirão Preto, University of São Paulo (DGO-FRMP-USP), Ribeirão Preto, Brazil; ${ }^{5}$ San Juan University Hospital/Miguel Hernández University, Alicante, Spain; ${ }^{6}$ Department of Obstetrics and Gynecology, University of Navarra, Pamplona, Spain; ${ }^{7}$ Harvard Medical School, Boston, MA, USA; ${ }^{8}$ Acute Gynaecology, Early Pregnancy and Advanced Endosurgery Unit, Nepean Hospital, Sydney Medical School Nepean, University of Sydney, Sydney, NSW, Australia; ${ }^{9}$ Eunice Kennedy Shriver National Institute of Child Health and Human Development, Bethesda, MD, USA; ${ }^{10}$ Carl von Ossietzky University Oldenburg, Oldenburg, Germany; ${ }^{11}$ Department of Obstetrics \& Gynecology, Augusta University, Augusta, GA, USA; ${ }^{12}$ Department of Gynaecology and Reproductive Medicine, University Medical Center Utrecht, Utrecht, The Netherlands; ${ }^{13}$ Department of Gynaecology, University Hospital Ghent, Ghent, Belgium; ${ }^{14}$ Department of Obstetrics and Gynecology, University of Cagliari, Cagliari, Italy; ${ }^{15}$ Division of Reproductive Endocrinology and Infertility, Department of Obstetrics and Gynecology, Duke University Medical Center, Durham, NC, USA;

${ }^{16}$ Department of Radiology, Beth Israel Deaconess Medical Center, Boston, MA, USA; ${ }^{17}$ Department of Obstetrics \& Gynecology, Wright State University, Boonshoft School of Medicine, Dayton, OH, USA; ${ }^{18}$ Instituto Valenciano de Infertilidad, Valencia, Spain; ${ }^{19}$ University of Florence, Florence, Italy; ${ }^{20}$ University College London Hospital, London, UK

KEYWORDS: agreement; dysmorphic uterus; Mullerian ducts; T-shaped uterus; uterine anomalies

\section{CONTRIBUTION}

What are the novel findings of this work?

The prevalence, clinical relevance and appropriateness of management of T-shaped uterus is not fully understood, due to the lack of objective criteria for its diagnosis. This study developed an objective definition of T-shaped uterus based on the diagnosis made most often by representative expert clinicians, surgeons and sonologists. We identified three uterine morphometric measurements in the coronal plane, with cut-offs (lateral internal indentation depth $\geq 7 \mathrm{~mm}$, lateral indentation angle $\leq 130^{\circ}$ and $\mathrm{T}$-angle $\leq 40^{\circ}$ ) that have good diagnostic test accuracy and fair-to-moderate reliability for the diagnosis of T-shaped uterus.

What are the clinical implications of this work? These three measurements, with cut-offs, can be used to confirm the diagnosis when there is suspicion of T-shaped uterus on subjective assessment of the uterine cavity. When these CUME definitions and criteria are used, doctors and patients can be confident that the diagnosis of T-shaped uterus has high probability of being correct. Using these criteria will allow elucidation in future studies of the prevalence, clinical relevance and management of T-shaped uterus.
ABSTRACT
Objectives To identify uterine measurements that are reliable and accurate to distinguish between $T$-shaped and normal/arcuate uterus, and define T-shaped uterus, using Congenital Uterine Malformation by Experts (CUME) methodology, which uses as reference standard the decision made most often by several independent experts.
Methods This was a prospectively planned multirater reliability/agreement and diagnostic accuracy study, performed between November 2017 and December 2018, using a sample of 100 three-dimensional (3D) datasets of different uteri with lateral uterine cavity indentations, acquired from consecutive women between 2014 and 2016. Fifteen representative experts (five clinicians, five

Correspondence to: Prof. A. Ludwin, Department of Gynecology and Oncology, Jagiellonian University, Kopernika 23, 31-501 Krakow, Poland (e-mail: ludwin@cm-uj.krakow.pl); Prof. W. P. Martins, Department of Obstetrics and Gynecology, Ribeirão Preto Medical School, University of São Paulo (DGO-FMRP -USP) Av. Bandeirantes, 3900, 8 andar, HCRP, Campus Universitario, Ribeirão Preto, São Paulo, Brazil 14048-900 (e-mail: wpmartins@gmail.com)

Accepted: 1 August 2019 
surgeons and five sonologists), blinded to each others' opinions, examined anonymized images of the coronal plane of each uterus and provided their independent opinion as to whether it was T-shaped or normallarcuate; this formed the basis of the CUME reference standard, with the decision made most often (i.e. that chosen by eight or more of the 15 experts) for each uterus being considered the correct diagnosis for that uterus. Two other experienced observers, also blinded to the opinions of the other experts, then performed independently 15 sonographic measurements, using the original $3 D$ datasets of each uterus. Agreement between the diagnoses made by the 15 experts was assessed using kappa and percent agreement. The interobserver reliability of measurements was assessed using the concordance correlation coefficient (CCC). The diagnostic test accuracy was assessed using the area under the receiver-operating-characteristics curve (AUC) and the best cut-off value was assessed by calculating Youden's index, according to the CUME reference standard. Sensitivity, specificity, negative and positive likelihood ratios ( $L R-$ and $L R+)$ and post-test probability were calculated.

Results According to the CUME reference standard, there were 20 T-shaped and 80 normal/arcuate uteri. Individual experts recognized between 5 and 35 (median, 19) T-shaped uteri on subjective judgment. The agreement among experts was $82 \%$ (kappa $=0.43)$. Three of the 15 sonographic measurements were identified as having good diagnostic test accuracy, according to the CUME reference standard: lateral indentation angle $(A U C=0.95)$, lateral internal indentation depth $(A U C=0.92)$ and $T$-angle (AUC $=0.87)$. Of these, T-angle had the best interobserver reproducibility (CCC $=0.87$ vs 0.82 vs 0.62 for $T$-angle vs lateral indentation depth vs lateral indentation angle). The best cut-off values for these measurements were: lateral indentation angle $\leq 130^{\circ}$ (sensitivity, $80 \%$; specificity, $96 \% ; L R+, 21.3 ; L R-, 0.21)$, lateral indentation depth $\geq 7 \mathrm{~mm}$ (sensitivity, $95 \%$; specificity, $77.5 \%$; $L R+, 4.2 ; L R-, 0.06$ ) and $T$-angle $\leq 40^{\circ}$ (sensitivity, $80 \%$; specificity, $87.5 \% ; L R+, 6.4 ; L R-, 0.23)$. Most of the experts diagnosed the uterus as being $T$-shaped in $0 \%$ (0/56) of cases when none of these three criteria was met, in $10 \%(2 / 20)$ of cases when only one criterion was met, in $50 \%(5 / 10)$ of cases when two of the three criteria were met, and in 93\% (13/14) of cases when all three criteria were met.

Conclusions The diagnosis of T-shaped uterus is not easy; the agreement among experts was only moderate and the judgement of individual experts was commonly insufficient for accurate diagnosis. The three sonographic measurements with cut-offs that we identified (lateral internal indentation depth $\geq 7 \mathrm{~mm}$, lateral indentation angle $\leq 130^{\circ}$ and $T$-angle $\leq 40^{\circ}$ ) had good diagnostic test accuracy and fair-to-moderate reliability and, when applied in combination, they provided high post-test probability for T-shaped uterus. In the absence of other anomalies, we suggest considering a uterus to be normal when none or only one criterion is met, borderline when two criteria are met, and T-shaped when all three criteria are met. These three CUME criteria for defining T-shaped uterus may aid in determination of its prevalence, clinical implications and best management and in the assessment of post-surgical morphologic outcome. The CUME definition of T-shaped uterus may help in the development of interventional randomized controlled trials and observational studies and in the diagnosis of uterine morphology in everyday practice, and could be adopted by guidelines on uterine anomalies to enrich their classification systems. Copyright (c) 2019 ISUOG. Published by John Wiley \& Sons Ltd.

\section{INTRODUCTION}

In the mid-20th century, there were considered to be three basic, normal morphological variants of the uterine cavity: (i) almost triangular in shape; (ii) with small lateral indentations; and (iii) with greater fundal and lateral indentations (Figure 1) ${ }^{1,2}$. T-shaped uterus was first described, based on hysterosalpingography findings, as a diethylstilbestrol (DES)-related congenital uterine anomaly, with the uterine cavity shape resembling the letter ' $\mathrm{T}$ ' 3 -7. Considering the DES-related etiology and morphology, T-shaped uterus was grouped by Buttram and Gibbons ${ }^{6}$ and the American Fertility Society (AFS) classification $^{8}$ into a separate class of anomalies, with no strict definition or morphometric criteria. However, of the 1-1.5 million women exposed to DES in utero, before its withdrawal from use during pregnancy in 1971 , there remain none of reproductive age ${ }^{9,10}$, and yet T-shaped uterus continues to be identified in this group of women, albeit rarely, in this post-DES era ${ }^{7,11}$. T-shaped uterus may be of primary origin ${ }^{12}$ or secondary to intrauterine adhesion syndrome ${ }^{7}$, tuberculosis ${ }^{13}$ or adenomyosis ${ }^{14}$. It has been suggested that it may be related to reproductive failure, such as infertility ${ }^{7,12,15-18}$ and recurrent miscarriage $\mathrm{e}^{7,12,16-18}$, but the clinical relevance of the non-DES-related T-shaped uterus is far from clear and this is not helped by the lack of an objective definition and consensus regarding its diagnosis. However, the quality of evidence is not good.

In 2013, the European Society of Human Reproduction and Embryology/European Society for Gynaecological Endoscopy (ESHRE-ESGE) published a guideline in which T-shaped uterus was defined subjectively as a narrow uterine cavity due to thickened lateral walls ${ }^{19}$. It did not specify objective criteria with which to diagnose $\mathrm{T}$-shaped uterus or explain how the uterine measurements should be performed. Among the various modifications of the AFS system, supplemented by morphometric criteria, that of Salim ${ }^{20}$ did not include T-shaped uterus as an anomaly, that of Ludwin ${ }^{11} \mathrm{did}$ not provide measurable criteria for $\mathrm{T}$-shaped uterus, and the recent official definitions published by the American Society for Reproductive Medicine (ASRM) ${ }^{21}$ are for only normal/arcuate, septate and bicornuate uterus. Until now, no objective and measurable criteria have been described for identifying T-shaped uterus, and this is a considerable 
(a)

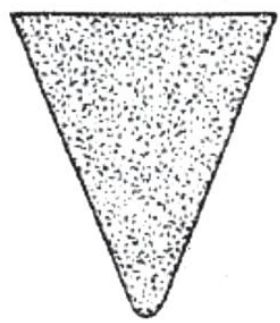

(b)

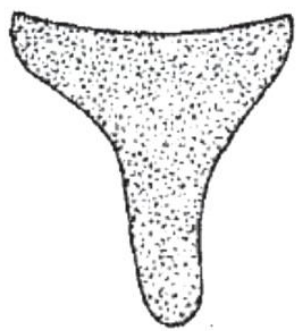

(c)

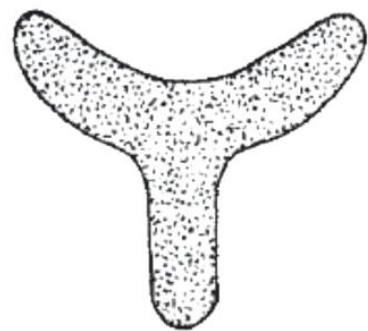

Figure 1 Three basic types of normal uterine cavity based on hysterosalpingography, according to Schultze and Erbsloh ${ }^{1}$ : (a) triangular cavity; (b) cavity with small fundal and lateral indentations; and (c) cavity with larger fundal and lateral indentations.

barrier to amassing evidence on its prevalence, its clinical implications and optimal management of this morphology.

Recently, the Congenital Uterine Malformation by Experts (CUME) initiative was developed to establish measurable criteria and definitions for normal and abnormal uterine morphology, build common language and unify the classification systems based on reliability/agreement and accuracy testing 22 . This methodology is based on the assumption that the option selected most often by several independent experts, blinded to each others' opinions, regarding uterine images, would be the best available reference standard with which to estimate diagnostic test accuracy and identify the best cut-off values for measurements.

The present study aimed to identify uterine measurements that are sufficiently reliable and accurate to distinguish between T-shaped and normal/arcuate uterus, and define T-shaped uterus, using CUME methodology for the reference standard.

\section{METHODS}

\section{Study design}

This was a prospectively planned multirater reliability/agreement and diagnostic accuracy study, performed between November 2017 and December 2018. The Guidelines for Reporting Reliability and Agreement Studies (GRRAS) ${ }^{23}$ and the STrengthening the Reporting of Observational studies in Epidemiology (STROBE) statement ${ }^{24}$ were used in the design and reporting of the study. The standardized design and principles of methodology (the CUME methodology) were similar to those used in our recent study to develop a definition distinguishing between normal/arcuate and septate uterus ${ }^{22}$. The target reference standard used in the CUME methodology is multiexpert reference standard, and three-dimensional (3D) ultrasound is used as a reference diagnostic tool. The target population is women of reproductive age, with specific uterine appearance, which may be interpreted as T-shaped or normal/arcuate depending on appearance of lateral indentations. This study was part of a large prospective observational project on screening, diagnosis and classification of congenital uterovaginal malformations by ultrasound. The project and this study were approved by the local ethics committee (KBET/236/B/2013) and written informed consent was obtained from all patients.

We planned to include 3D datasets from 100 different uteri with lateral internal indentations and with fundal internal indentation $<10 \mathrm{~mm}$, identified from all datasets preacquired by an experienced observer from consecutive women between 2014 and 2016. Two independent observers prepared from the 3D datasets two-dimensional (2D) images in the coronal view for all uteri, and 15 invited experts provided independently their subjective assessment of the images. Two raters, who were at level three in terms of experience according to the European Federation of Societies for Ultrasound in Medicine and Biology (EFSUMB, www.efsumb.org), with at least 15 years of experience in 3D ultrasound examination, obtained independently specific target measurements of each uterus using the same unprocessed 3D datasets. The field of expertise, number of years of experience and country of residence of the included experts and observers are presented in Table S1.

\section{Main and secondary outcome measures}

Our main outcomes were the CUME process of establishing the reference for diagnosis and classification of $\mathrm{T}$-shaped uterus and the level of agreement among experts in the recognition of $\mathrm{T}$-shaped uterus using subjective judgment based on review of coronal images from 3D ultrasound volumes. Secondary outcomes were: (i) the interobserver reliability/agreement for measurements potentially useful as objective diagnostic criteria for $\mathrm{T}$-shaped uterus and to distinguish T-shaped uterus from normal/arcuate uterus; (ii) the diagnostic test accuracy and the best cut-off values for these measurements, using the CUME reference standard (multiexpert opinion); (iii) a definition of $\mathrm{T}$-shaped uterus, using the most accurate and reliable objective measurable criteria with reasonable post-test probability of this morphology, suitable for use in trials, observations and clinical practice.

\section{Setting and patients}

The study included 3D ultrasound datasets of uteri from women of reproductive age (18-45 years), who were recruited for detailed evaluation at a single recruitment center, a private clinic (Ludwin and Ludwin Gynecology, 
Krakow, Poland) specializing in the management of congenital uterine anomalies. Excluded from the main project were women with unexpected pregnancy detected during the evaluation, menopause, malignancy, benign lesions distorting the uterine cavity shape and/or uterine wall, and those with previous uterine surgery. Obvious uterine morphologies that were not considered as T-shaped uteri (namely, normal/arcuate uterus without lateral indentation, uterine agenesis and unicornuate, bicornuate, didelphic and septate uteri) were ineligible for this study. Asymmetrical uteri with a lateral indentation on one side were not excluded.

For the main project, all patient data and 3D ultrasound datasets were collected prospectively and aggregated in a large database at Jagiellonian University, Department of Gynecology and Oncology, Krakow, Poland. However, for the purposes of the current study we retrieved using online software (Google forms and Dropbox) only stored unprocessed 3D ultrasound volumes; the demographic data, previous measurements and previous real-time and offline diagnoses were not used and did not influence the study results.

\section{Ultrasound examination}

The ultrasound imaging technique used has been described previously ${ }^{11,22}$. Uteri were evaluated by $2 \mathrm{D}$ and 3D transvaginal ultrasound (or transrectal in case of intact hymen). Voluson E8 and Expert BT13 (GE Healthcare, Zipf, Austria) ultrasound systems, equipped with volumetric intravaginal probes (GE RIC, 5-9 MHz), were used for acquisition of $3 \mathrm{D}$ datasets in a standardized manner (sagittal view of uterus; maximum sweep angle $120^{\circ}$ and maximum quality; approximate angle between ultrasound beam and uterine axis $=90^{\circ}$; 3D volume acquisition while patient breath-held and refrained from movement). Two different 3D datasets of each uterus were obtained, recorded and stored for all women, after confirmation that the entire uterus had been captured in the $3 \mathrm{D}$ volume. If necessary, the acquisition was repeated in the transverse plane, which is more appropriate than acquisition in the sagittal plane for uteri with larger transverse diameter, although in these acquisitions the entire uterus with cervix may be only partially visible in the coronal view. Women with regular menstrual cycles were examined between days 17 and 25 of the cycle, since the secretory phase facilitates visualization of the endometrial cavity. Women with irregular cycles or amenorrhea and those using hormonal contraception were examined independently of the stage of the menstrual cycle, but not during menstruation. All ultrasound examinations were performed in real time by one of two experienced sonologists (I.L., A.L.; experience level three, according to EFSUMB, and at least 15 years of experience with 3D-US).

\section{Sample size}

The sample sizes for subjects $(n=100)$, raters for subjective judgment $(n=15)$, observers for preparing the images to be sent to the experts $(n=2)$ and raters for performing the measurements $(n=2)$ are standardized for our CUME exploratory studies for specific definitions, and are based on the available guidelines for reliability/agreement studies ${ }^{25,26}$. In fact, it has been argued in the field of reliability studies that the increase in precision of reliability coefficients achieved by using sample sizes of more than 50 subjects and more than three raters is rarely worth the additional effort required ${ }^{27}$. However, we chose arbitrarily to increase our target sample size to 100 subjects in order to achieve an interval of confidence of $95 \%$ for the concordance correlation coefficient (CCC) of 0.2 , considering the expected CCC of at least 0.80 by two raters. Also, as in our previous study ${ }^{22}$, we similarly selected arbitrarily an increased sample size of expert raters, feeling that 15 expert raters (five raters in each of three fields; specifically, clinicians specializing in reproductive medicine and/or congenital uterine anomalies, surgeons, and sonologists) would provide more generalizable results than would be possible with participation of only three experts.

\section{Subject selection and preparation of images}

Subject selection for the current study was based on consecutive inclusion of 3D datasets of uteri from women with specific uterine features (presence of uterine cavity lateral indentations). 3D datasets of consecutive women included in the main project were specifically re-assessed for this study by an experienced sonologist (I.L.) until 100 uteri fitting our eligibility criteria had been identified. The presence of lateral indentation was judged subjectively. When present, fundal indentations were measured, to confirm that they were smaller than $10 \mathrm{~mm}$.

A single 3D volume of the uterus of each woman was anonymized, numbered, stored and sent to two observers from another institution (M.A.C.N., W.C., both with 3 years of experience in 3D-ultrasound imaging), who prepared for assessment by the invited experts images of the coronal view, using two different ultrasound techniques. One combined OmniView with volume contrast imaging (VCI); Omniview provides a rendered view of the coronal plane by curved rendered mode, which allows identification of the internal os in the coronal plane of the uterus, and VCI is a tool that enhances the contrast between tissues and organs ${ }^{28}$. The other, HDlive, also allows use of a curved rendered mode and enhances the depth of perception, generating a realistic appearance ${ }^{29}$. These imaging modalities were chosen because they were preferred according to independent multiexpert opinion in the first CUME study ${ }^{22}$. Each of the two observers prepared half of the images and all were then reviewed by two more experienced observers (A.L. and W.P.M.), who confirmed that the correct coronal view of each uterus had been obtained, with both uterine cavity horns, cervical canal and internal cervical os visible. If necessary, the observer was asked to correct the coronal plane and prepare a new image. The pair of images for each uterus were then combined into a single image set (presented 
T-shaped uterus
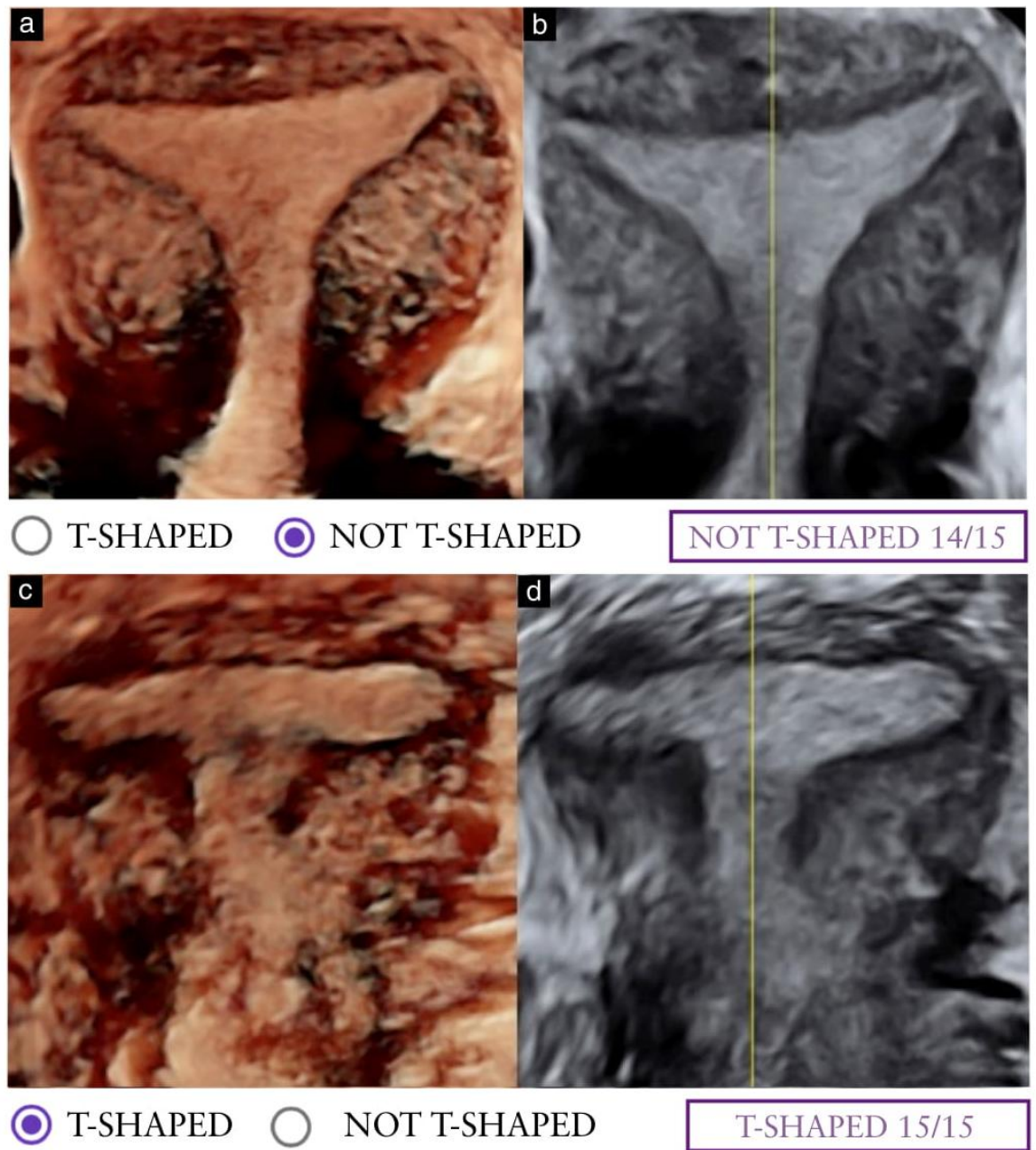

Figure 2 Example of image pairs of two uteri, displayed using two 3D ultrasound modalities: HDlive (a,c) and Omniview with volume contrast imaging $(\mathrm{b}, \mathrm{d})$. One hundred such pairs of images were sent to 15 experts for subjective assessment regarding whether uterus was T-shaped, and decision made by the majority (i.e. at least eight of the 15 experts) was used as CUME reference standard. (a,b) Example of uterus which the majority (14/15) decided was not T-shaped. (c,d) Example of uterus which all experts (15/15) judged to be T-shaped.

side-by-side; Figure 2) and all 100 image pairs were sent to each of the 15 experts for subjective judgment regarding whether the uterus was T-shaped. Subjective judgment was used because, at this level of expertise (especially clinicians and surgeons), it is common practice that final diagnosis is made in this way, i.e. subjectively based on imaging results. Ultrasound measurements were also performed offline by two expert raters (A.L and W.P.M.) independently, using the unprocessed $3 \mathrm{D}$ volumes.

\section{Expert selection}

The principles and eligibility criteria for recruitment of experts were the same as those described previously for building the CUME group, based on reliable information about expertise $\mathrm{e}^{22}$. We invited to join the CUME group: (i) editors-in-chief/deputy editors/members of editorial boards of journals with the highest impact in the fields of gynecology and reproductive medicine, imaging and/or gynecological surgery; (ii) presidents or members of executive committees of nine targeted societies in the field (Table S1); and (iii) experts globally well-known in these fields due to their publications on uterine anomalies. All invited experts had at least 50 publications in the field of obstetrics, gynecology, gynecological surgery and/or imaging and all were required to give their consent to participate. Considered as ineligible were experts involved in previous consensuses on the measurable criteria for congenital uterine malformations, those with known potential personal or financial conflict of interest regarding promotion of specific criteria, societies or surgical procedures (surgery of T-shaped uterus) and close friends or coworkers from the same institutions. Hence, we used the same initial list of 15 experts and supplementary list of six experts (two per field) that were used in the first CUME study ${ }^{22}$. If someone from the initial list did not agree to participate or had not responded within 7 days, we then invited consecutively from the supplementary list another expert from the same field. To avoid bias, the experts were blinded to the opinions of each other. 


\section{Rating process}

An online questionnaire was created for this study and the link (https://goo.gl/forms/s947iFtit5T7rwBf2) was sent to the members of the expert panel (CUME group). This presented the experts with a dichotomous question for each image pair: T-shaped $v$ s not T-shaped.

\section{Clinical definitions for experts}

We did not consider it appropriate to define and recognize T-shaped uterus according to clinical definitions regarding additional morphological features, benchmarks or potential reproductive outcomes of this morphology because there are no objective criteria with which to identify T-shaped uterus and there is no evidence regarding whether T-shaped uterus (that is not DES-related) is associated with worse reproductive outcome. We also avoided any suggestions that $\mathrm{T}$-shaped uterus is a congenital uterine malformation because there is no evidence that this morphology is a result of embryological disorders. The experts were simply asked to identify subjectively uterine cavities as (i) T-shaped or (ii) not T-shaped. The experts had no access to any measurement or clinical information, with the exception that they knew that none of the included women had been exposed to DES.

\section{Ultrasound measurements and their selection}

Two experts (A.L., W.P.M.), who were blinded to the opinion of the other experts, proposed independently potentially useful measurements for differentiation of T-shaped uterus from normal/arcuate uterus. Through discussion, they established a standardized set of 15 measurements (11 types of measurement, with four being pairs of symmetrical measurements performed on both left and right sides) and their methodology. Any measurement without a direct association with the uterine cavity was not considered; for example, uterine-wall thickness, because the uterine cavity shape and degree of deformity are commonly independent of this. We tested each of the symmetrical measurements separately and also calculated their average. Additionally, ratios of some of the measurements were selected for calculation by consensus.

The proposed measurements, illustrated in Figure 3 and detailed in Table 1 , were: fundal internal indentation depth $^{22,30}$; lateral internal indentation depth (on left and right sides); circle area of the uterine cavity; uterine cavity area, traced manually; uterine cavity circumference; uterine cavity length; uterine cavity width; fundal indentation angle; lateral indentation angles (right and left); cornual angles (right and left); and T-angle. We determined the position of the internal os by subjective impression based on three criteria: the region of echogenicity transition (myometrium is brighter and cervix is darker), the position of uterine vessels, and the narrowest point of the 'hourglass sign' formed between the uterine and cervical cavities.
The two observers performing the measurements (A.L. and W.P.M.) did so by manipulating independently the same initial dataset of each uterus, to obtain the midcoronal plane of the uterus, using Omniview with VCI mode. Omniview with VCI was selected for the measurements because it is easier to manipulate compared with HDlive and it facilitates identification of the internal os.

\section{Bayes' theorem and definition of T-shaped uterus}

Assessment of reliability/agreement and accuracy to identify the best of the 15 measurements was the first step in the selection of criteria and development of a definition for T-shaped uterus. Bayes' theorem adopted by Fagan $^{31}$ was used to quantify the post-test probability of $\mathrm{T}$-shaped uterus and to establish a definition considering the highest post-test probability of women in the target population having T-shaped uterus. This approach is standard in evidence-based medicine $\mathrm{e}^{32}$ and clinically applied epidemiology for interpretation of diagnostic accuracy studies ${ }^{33}$.

\section{Statistical analysis}

Analyses were conducted using GraphPad Prism version 6 (GraphPad Software Inc., San Diego, CA, USA), IBM SPSS Statistics 22 (IBM Corp., Armonk, NY, USA) and Stata version 13.0 (StataCorp LP, College Station, TX, USA). Agreement between all experts, and agreement between experts with respect to area of expertise (clinicians, surgeons and sonologists) was assessed using the kappa index (Fleiss kappa for multiple raters) and proportion of agreement (percent agreement $)^{34}$. The margins of variability/error between the two experts who performed the measurements were estimated by limits of agreement (LoA). Interobserver reliability and agreement of the uterine measurements were expressed by the CCC and LoA and the coefficient of repeatability (CoR). These statistical indices and coefficients were interpreted with regard to reporting strength of agreement/reproducibility as follows ${ }^{35}$ : poor: kappa $<0.2$, ICC/CCC $<0.7$, CoR (relative differences) $>50 \%$; fair: kappa $0.2-0.4$, ICC/CCC 0.7-0.9, CoR (relative differences) 20-50\%; moderate: kappa $0.41-0.60$, ICC/CCC 0.90-0.95, CoR (relative differences) 10 to $<20 \%$; good: kappa $0.61-0.80$, ICC/CCC 0.95-0.99; CoR (relative differences) 5 to $<10 \%$; very good: kappa 0.81-1.00, ICC/CCC > 0.99; CoR (relative differences) $<5 \%$.

The area under the receiver-operating-characteristics curve (AUC) was used to estimate diagnostic test accuracy, and Youden's index was used to find the best cut-off value, according to the CUME reference standard. Sensitivity, specificity and negative and positive likelihood ratios (LR- and $\mathrm{LR}+$ ) were calculated. A Fagan nomogram generated online by Schwartz's calculator (http://araw.mede.uic.edu/cgi-bin/testcalc.pl) was used to estimate by how much the most accurate criteria and their combination would change the probability of a 


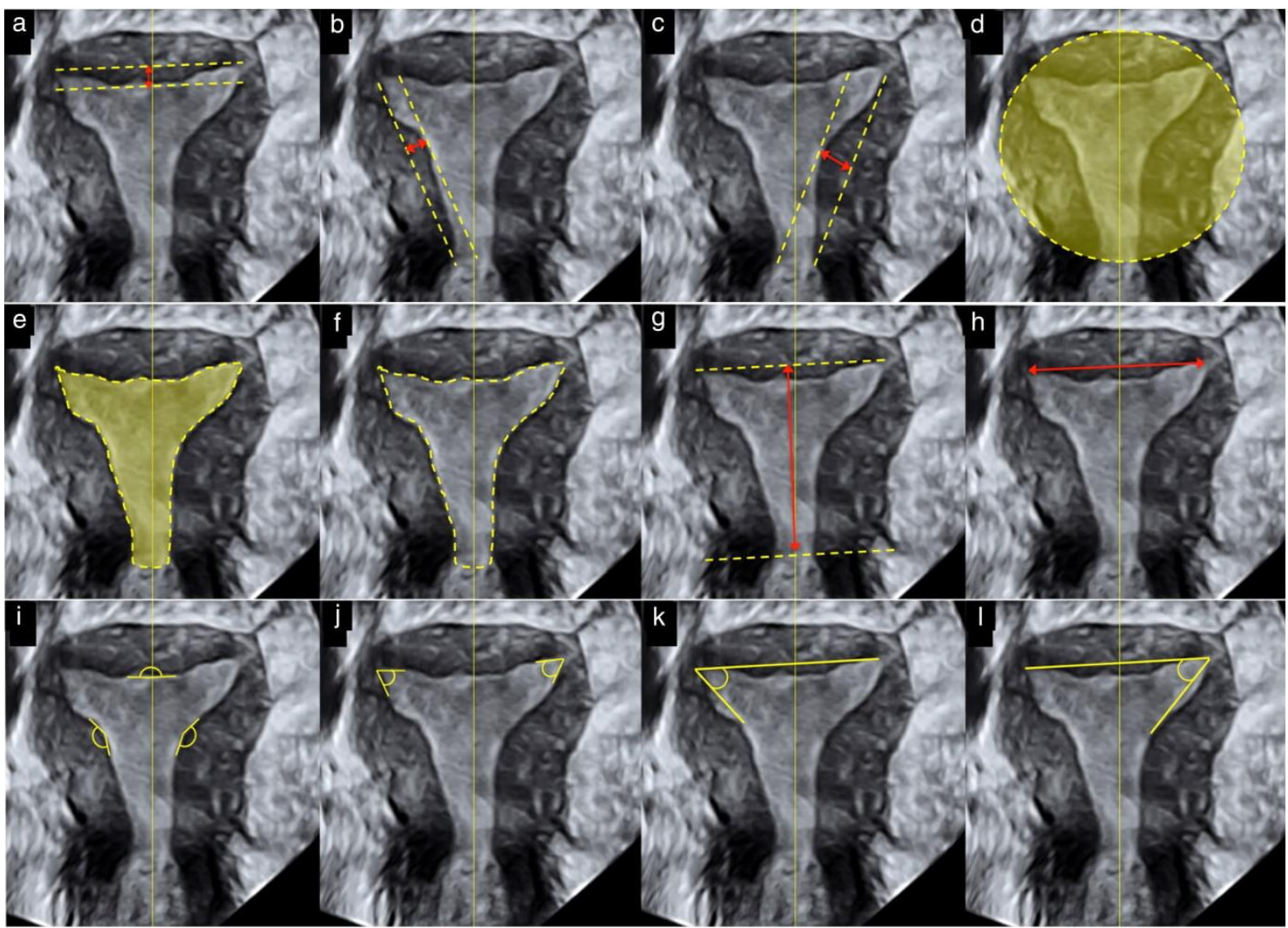

Figure 3 Demonstration of 15 proposed measurements for recognition of T-shaped uterus: (a) fundal internal indentation depth; (b) right lateral internal indentation depth; (c) left lateral internal indentation depth; (d) circle area of uterine cavity (ellipse function); (e) uterine cavity area (manual trace); (f) uterine cavity circumference; (g) uterine cavity length from intercornual line to internal os; (h) uterine cavity width (intercornual); (i) fundal angle and right and left lateral indentation angles; (j) right and left cornual angles; (k) right T-angle; (l) left T-angle. Symmetrical measurements from left and right sides were used to calculate average value for these measurements. Selected measurements were used for creation of indices: uterine cavity area/uterine cavity circle area, uterine cavity area/uterine cavity circumference and uterine cavity area/uterine cavity circumference ${ }^{2}$.

uterus being T-shaped (posterior probability) in the target population ${ }^{31}$. Pretest probability was based on the prevalence of $\mathrm{T}$-shaped uterus according to the diagnosis made most often by experts in the target population (suspicion of T-shaped uterus). Agreement, diagnostic accuracy of each of the invited experts (subjective judgment of single experts), diagnoses based on the most accurate measurements and combinations of these measurements in comparison with the CUME reference standard were expressed by the kappa statistic, and their accuracy was compared using the McNemar test. We assessed the correlation (Spearman's) of each parameter with the sum of votes from the invited experts. Statistical significance was defined by $P \leq 0.05$.

\section{RESULTS}

3D datasets of 2179 uteri of consecutive women were assessed as potentially eligible in order to select for inclusion in the study a sample of 100 3D datasets of uteri with lateral internal indentation.

\section{Diagnosis of T-shaped uterus}

According to CUME, using as reference standard the decision made most often by the experts (i.e. by eight or more of the 15), there were $20 \mathrm{~T}$-shaped and 80 normal/arcuate uteri. The median number of diagnoses of T-shape per expert was 19 , and the minimum and maximum diagnoses of $\mathrm{T}$-shape per expert were 5 and 35 , respectively (Table 2 ).

\section{Agreement between experts (subjective evaluation)}

Of the 1500 decisions overall ( 15 experts $\times 100$ datasets), there were $305(20 \%)$ of T-shaped uterus, with a moderate level of agreement between experts $(\mathrm{kappa}=0.43)$ and an observed agreement of $82 \%$ (Table 3 ). There were differences in level of agreement as expressed by kappa among the different groups of experts: sonologists and clinicians had a moderate level of agreement (kappa $=0.45$ and 0.48 , respectively), while surgeons achieved a fair level $(\mathrm{kappa}=0.31)$. Percent agreement was close to 
Table 1 Description of 15 proposed ultrasound measurements for differentiation of T-shaped uterus from normal/arcuate uterus

\begin{tabular}{|c|c|c|}
\hline Parameter & Unit & Description \\
\hline Fundal internal indentation depth & $\mathrm{mm}$ & $\begin{array}{l}\text { Distance between intercornual line (line connecting highest points of endometrial cavity } \\
\text { on each side of uterus) and lowest point/nadir of fundal internal indentation }{ }^{22,30}\end{array}$ \\
\hline \multicolumn{3}{|l|}{ Lateral internal indentation depth } \\
\hline Right & $\mathrm{mm}$ & $\begin{array}{l}\text { Distance between line connecting internal os to most lateral point of uterine cavity and } \\
\text { line crossing apex of lateral indentation, right side }\end{array}$ \\
\hline Left & $\mathrm{mm}$ & $\begin{array}{l}\text { Distance between line connecting internal os to most lateral point of uterine cavity and } \\
\text { line crossing apex of lateral indentation, left side }\end{array}$ \\
\hline Circle area of uterine cavity & $\mathrm{cm}^{2}$ & $\begin{array}{l}\text { Area of circle touching three points (two most lateral points of uterine cavity and } \\
\text { internal os) }\end{array}$ \\
\hline Uterine cavity area & $\mathrm{cm}^{2}$ & $\begin{array}{l}\text { Area of uterine cavity (traced manually), including all external limits of endometrial } \\
\text { cavity, and inferior limit being internal os }\end{array}$ \\
\hline Uterine cavity circumference & $\mathrm{cm}$ & Circumference of uterine cavity (traced manually) \\
\hline Uterine cavity length & $\mathrm{mm}$ & Distance between intercornual line and internal os \\
\hline Uterine cavity width & $\mathrm{mm}$ & Distance between two most lateral points of uterine cavity \\
\hline Fundal indentation angle & degrees & $\begin{array}{l}\text { Based on three points: apex/lowest point of fundal internal indentation and two points on } \\
\text { myometrial/endometrial interface, } 5 \mathrm{~mm} \text { distant from first point, one to each side of it }\end{array}$ \\
\hline \multicolumn{3}{|l|}{ Lateral indentation angle } \\
\hline Right & degrees & $\begin{array}{l}\text { Based on three points: apex of right lateral indentation and two points on } \\
\text { myometrial/endometrial interface, } 5 \mathrm{~mm} \text { distant from first point, one to each side of it }\end{array}$ \\
\hline Left & degrees & $\begin{array}{l}\text { Based on three points: apex of left lateral indentation and two points on } \\
\text { myometrial/endometrial interface, } 5 \mathrm{~mm} \text { distant from first point, one to each side of it }\end{array}$ \\
\hline \multicolumn{3}{|r|}{ 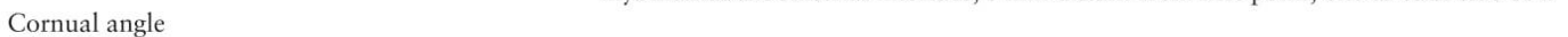 } \\
\hline Right & degrees & $\begin{array}{l}\text { Based on three points: most lateral point of uterine cavity on right side, and two points on } \\
\text { myometrial/endometrial interface, } 5 \mathrm{~mm} \text { distant from first point, one to each side of it }\end{array}$ \\
\hline Left & degrees & $\begin{array}{l}\text { Based on three points: most lateral point of uterine cavity on left side, and two points on } \\
\text { myometrial/endometrial interface, } 5 \mathrm{~mm} \text { distant from first point, one to each side of it }\end{array}$ \\
\hline \multicolumn{3}{|r|}{ ( } \\
\hline Right & degrees & $\begin{array}{l}\text { Based on three points (most lateral point of uterine cavity on right side, contralateral } \\
\text { most lateral point of uterine cavity and apex of ipsilateral lateral indentation) }\end{array}$ \\
\hline Left & degrees & $\begin{array}{l}\text { Based on three points (most lateral point of uterine cavity on left side, contralateral most } \\
\text { lateral point of uterine cavity and apex of ipsilateral lateral indentation) }\end{array}$ \\
\hline $\begin{array}{l}\text { Uterine cavity area/uterine cavity } \\
\text { circle area }\end{array}$ & None & $\begin{array}{l}\text { Uterine cavity area (traced manually) divided by area of circle touching three points } \\
\text { (most lateral points of uterine cavity and internal os) }\end{array}$ \\
\hline $\begin{array}{l}\text { Uterine cavity area/uterine cavity } \\
\text { circumference }\end{array}$ & None & $\begin{array}{l}\text { Uterine cavity area (traced manually) divided by uterine cavity circumference (manual } \\
\text { drawing) }\end{array}$ \\
\hline $\begin{array}{l}\text { Uterine cavity area/uterine cavity } \\
\text { circumference }^{2}\end{array}$ & None & Uterine cavity area (traced manually) divided by (circumference of uterine cavity) ${ }^{2}$ \\
\hline
\end{tabular}

Table 2 Diagnoses of T-shaped uterus by subjective judgment of 15 experts, overall and according to their field of expertise

\begin{tabular}{lcccrr}
\hline & \multicolumn{5}{c}{ Number of diagnoses of T-shape } \\
\cline { 2 - 6 } Expert & Median & $p 25-p 75$ & Range & Mean & SD \\
\hline Clinicians $(n=5)$ & 33 & $19.5-34.5$ & $17-35$ & 28.2 & Total \\
Sonologists $(n=5)$ & 17 & $6.5-24$ & $6-29$ & 15.6 & 17.2 \\
Surgeons $(n=5)$ & 16 & $9.5-25.5$ & $5-27$ & 9.5 & 8.7 \\
All $(n=15)$ & 19 & $14-29$ & $5-35$ & 20.3 & 10.0 \\
\hline
\end{tabular}

Number of uteri $=100$. p25-p75, lower-upper quartile.

Table 3 Agreement between experts in recognizing T-shaped uterus using subjective judgment of mid-coronal view of uterus from three-dimensional ultrasound

\begin{tabular}{lccr}
\hline Expert & T-shape selected $(\mathrm{n} / \mathrm{N}(\%))$ & Kappa $(95 \% \mathrm{CI})$ & Percent agreement $(95 \%$ CI); $\mathrm{n} / \mathrm{N}$ * \\
\hline Clinicians $(n=5)$ & $141 / 500(28)$ & $0.48(0.41-0.55)$ & $79(76-81) ; 790 / 1000$ \\
Sonologists $(n=5)$ & $78 / 500(16)$ & $0.45(0.41-0.49)$ & $86(83-88) ; 856 / 1000$ \\
Surgeons $(n=5)$ & $86 / 500(17)$ & $0.31(0.23-0.39)$ & $80(78-83) ; 804 / 1000$ \\
Overall $(n=15)$ & $305 / 1500(20)$ & $0.43(0.39-0.47)$ & $82(81-82) ; 8566 / 10500$ \\
\hline
\end{tabular}

Number of uteri $=100$. ${ }^{*}$ Considering each subgroup of experts $(n=5)$, there are 10 pairwise comparisons for each uterus (Rater 1 vs

Rater 2, Rater 1 vs Rater 3, Rater 1 vs Rater 4, ..), resulting in a total of 1000 comparisons when assessing 100 subjects; considering all

15 experts, there are 105 pairwise comparisons for each uterus, resulting in a total of 10500 comparisons. 
$80 \%$, with the highest percent agreement being among expert sonologists $(86 \%)$, followed by surgeons $(80 \%)$ and clinicians $(79 \%)$. Clinicians diagnosed T-shaped uterus more often $(28 \%)$ than did surgeons $(17 \%)$ and sonologists $(16 \%)$.

\section{Interobserver reliability/agreement of ultrasound measurements}

The results of all measurements performed by the two observers, and the interobserver reliability/agreement of these measurements, are shown in Tables S2 and S3, respectively. Three measurements were identified as having good accuracy for the diagnosis of T-shaped uterus: average lateral internal indentation depth, average lateral indentation angle and $\mathrm{T}$-angle.
Their reliability was as follows: $\mathrm{CCC}=0.82,0.62$ and 0.87 , respectively (Table 4$)$. Relative and absolute differences between the measurements of the two observers for these three measurements are shown in Table 4 and Figure 4.

\section{Diagnostic test accuracy of measurements}

The diagnostic test accuracy of all measurements, using experts (CUME) as reference standard, is shown in Table S4. The lateral indentation angle $(\mathrm{AUC}=0.95)$, lateral indentation depth $(\mathrm{AUC}=0.92)$ and $\mathrm{T}$-angle $(\mathrm{AUC}=0.87)$ had good diagnostic test accuracy compared with subjective impression by experts (Table 5). The best cut-off values for these measurements were: lateral indentation angle $\leq 130^{\circ}$ (sensitivity $=80 \%$,

Table 4 Interobserver reliability/agreement of three most accurate measurements selected from 15 potentially useful measurements to establish objective diagnostic criteria for T-shaped uterus

\begin{tabular}{|c|c|c|c|c|c|}
\hline \multirow[b]{2}{*}{ Measurement } & \multicolumn{2}{|c|}{ Absolute difference } & \multicolumn{2}{|c|}{ Relative difference } & \multirow[b]{2}{*}{ CCC $(95 \% \mathrm{CI})$} \\
\hline & LoA & $\mathrm{CoR}$ & $\operatorname{LoA}(\%)$ & $\operatorname{CoR}(\%)$ & \\
\hline Lateral indentation depth & $-1.0 \mathrm{~mm}$ to $2.2 \mathrm{~mm}$ & $1.6 \mathrm{~mm}$ & -17 to 36 & 26 & $0.82(0.75-0.87)$ \\
\hline Lateral indentation angle & $-19^{\circ}$ to $19^{\circ}$ & $19^{\circ}$ & -14 to 14 & 14 & $0.62(0.48-0.73)$ \\
\hline T-angle & $-9^{\circ}$ to $7^{\circ}$ & $8^{\circ}$ & -20 to 15 & 18 & $0.87(0.82-0.91)$ \\
\hline
\end{tabular}

Number of uteri $=100$. CCC, concordance correlation coefficient; CoR, coefficient of repeatability; LoA, limits of agreement.
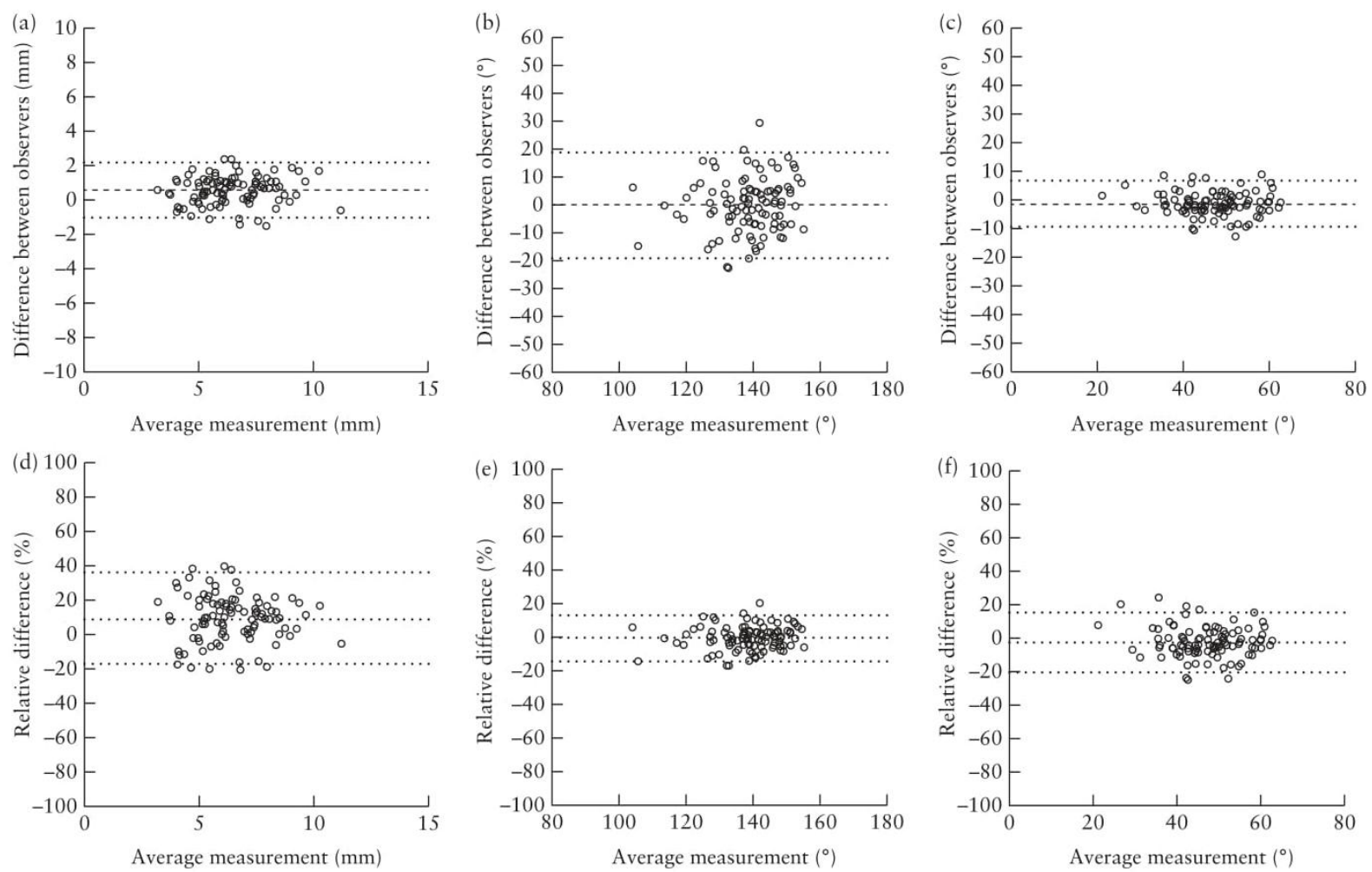

Figure 4 Bland-Altman plots for absolute $(a-c)$ and relative $(d-f)$ differences observed between uterine measurements of two expert observers: (a,d) lateral internal indentation depth; (b,e) lateral indentation angle; and (c,f) T-angle. Measurements are averages of left and right sides. 
specificity $=96 \%, \quad \mathrm{LR}-=0.21, \mathrm{LR}+=21.3)$, lateral indentation depth $\geq 7 \mathrm{~mm}$ (sensitivity $=95 \%$, specificity $=78 \%, \quad \mathrm{LR}-=0.06, \mathrm{LR}+=4.2)$ and $\mathrm{T}$-angle $\leq 40^{\circ}$ (sensitivity $=80 \%$, specificity $=88 \%$, LR $-=0.23$, $\mathrm{LR}+=6.4)$. Table S5 presents these best cut-offs for the selected measurements and their agreement with multiexpert opinion.

\section{The criteria, their frequency and diagnosis}

Among the 100 uteri assessed, the numbers meeting none, some or all of the three criteria identified as most accurate for identifying $\mathrm{T}$-shape (lateral internal indentation depth, lateral indentation angle and T-angle), along with the corresponding numbers of those considered to be $\mathrm{T}$-shaped or normal/arcuate, according to the diagnosis made most often by experts (CUME), were as follows:
- Met no criteria: $n=56$; all of these were considered normal/arcuate uterus;

- Met only one criterion: $n=20$, of which: 2 considered T-shaped; 18 considered normal/arcuate uterus;

- Met any two criteria: $n=10$, of which: 5 considered T-shaped; 5 considered normal/arcuate uterus;

- Met all three criteria: $n=14$, of which: 13 considered T-shaped; 1 considered normal/arcuate uterus.

Post-test probability of T-shaped uterus by three most accurate measurements and their combination

In Figure 5, by means of the Fagan nomogram, we present the estimated post-test probability of $\mathrm{T}$-shaped uterus for the target population, based on the known $20 \%$ pretest probability of T-shaped uterus (20/100 diagnoses of $\mathrm{T}$-shaped uterus according to the diagnosis made most often by CUME experts) and the LR+ (for presence of the

Table 5 Diagnostic test accuracy of three best measurements selected from 15 potentially useful measurements to establish objective diagnostic criteria for T-shaped uterus

\begin{tabular}{|c|c|c|c|c|c|c|}
\hline Measurement & $\begin{array}{c}\text { AUC } \\
(95 \% \mathrm{CI})\end{array}$ & $\begin{array}{c}\text { Spearman's } \\
\rho^{*}\end{array}$ & Cut-off & $\begin{array}{c}\text { Sensitivity } \\
(\%(95 \% \mathrm{CI}) ; \mathrm{n} / \mathrm{N})\end{array}$ & $\begin{array}{c}\text { Specificity } \\
(\%(95 \% \text { CI }) ; \mathrm{n} / \mathrm{N})\end{array}$ & $\begin{array}{l}\text { Youden's } \\
\text { index (J) }\end{array}$ \\
\hline Lateral indentation depth & $0.92(0.87-0.98)$ & 0.66 & $\geq 7 \mathrm{~mm}$ & $95(75-100) ; 19 / 20$ & $77.5(67-86) ; 62 / 80$ & 0.73 \\
\hline Lateral indentation angle & $0.95(0.90-0.99)$ & -0.73 & $\leq 130^{\circ}$ & $80(56-94) ; 16 / 20$ & 96 (89-99); 77/80 & 0.76 \\
\hline T-angle & $0.87(0.78-0.95)$ & -0.62 & $\leq 40^{\circ}$ & $80(56-94) ; 16 / 20$ & 87.5 (78-94); 70/80 & 0.68 \\
\hline
\end{tabular}

We considered as reference standard the diagnosis made most often among 15 experts. *Correlation with sum of diagnoses.
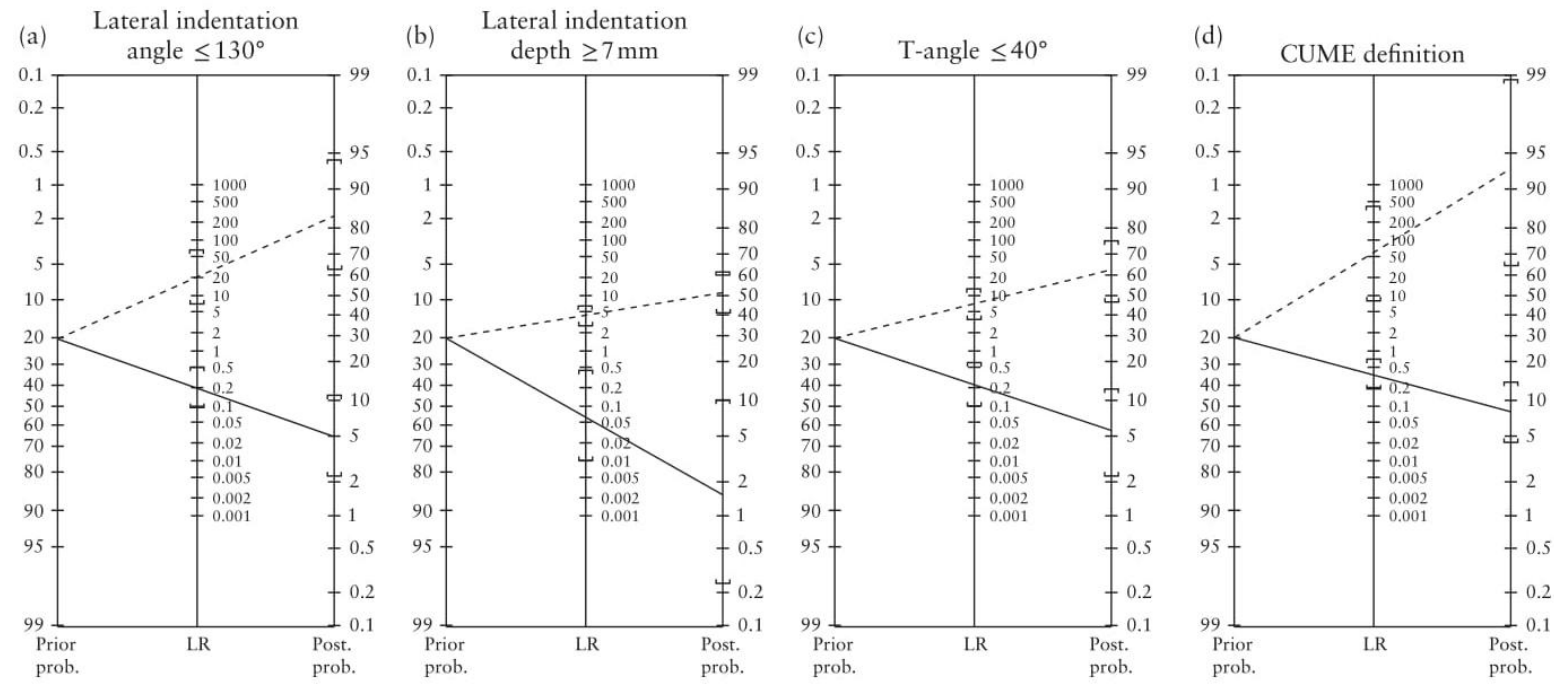

Figure 5 Fagan nomograms to determine probability of having T-shaped uterus based on optimal criteria identified in this study and on diagnosis made most often by experts as reference standard ${ }^{22}$ : lateral indentation angle $\leq 130^{\circ}$ (a), lateral indentation depth $\geq 7 \mathrm{~mm}$ (b) and T-angle $\leq 40^{\circ}$ (c) as single diagnostic criteria, and CUME definition of T-shaped uterus (presence of all three criteria) (d). Straight lines run from patient's pretest probability of T-shaped uterus (Prior prob.), in cases suspected of having T-shaped uterus due to presence of lateral cavity indentation (i.e. $20 \%$ ), to their post-test probability of disease (Post. prob.), representing positive (----) and negative (- likelihood ratios (LR) for presence and absence, respectively, of each criterion individually $(\mathrm{a}-\mathrm{c})$ and in combination (all three criteria present or absent) (d). Post-test probability of uterus being T-shaped increased $2-4$-fold in presence of lateral indentation angle $\leq 130^{\circ}(c .84 \%)$ or depth $\geq 7 \mathrm{~mm}(c .51 \%)$ or T-angle $\leq 40^{\circ}(c .62 \%)$ and was highest $(c .93 \%)$ in presence of all three, while it was very low $(1-5 \%)$ or low $(8 \%)$ in absence of one of these three or all three (CUME definition), respectively. 
criterion) or LR - (for absence of the criterion) values, for each criterion individually (diagnosis of T-shaped uterus in presence of each) and for their combination (diagnosis of $\mathrm{T}$-shaped uterus in presence of all three criteria). The post-test probabilities of a uterus being $\mathrm{T}$-shaped in the presence of lateral indentation angle $\leq 130^{\circ}$, lateral indentation depth $\geq 7 \mathrm{~mm}$, and T-angle $\leq 40^{\circ}$ were $84 \%$, $51 \%$ and $62 \%$, respectively, and in the absence of these criteria they were $5 \%, 1 \%$ and $5 \%$, respectively. The post-test probability of a uterus being $\mathrm{T}$-shaped in the presence of all three criteria was $93 \%$ and in the absence of this combination of all three (negative test results) it was $8 \%$.

\section{Individual experts' opinions $v s$ measurements $v s$ CUME reference}

The diagnostic accuracy measures and agreement expressed by kappa of individual experts, according to individual criteria and combinations of the three criteria relative to the CUME reference, i.e. the decision made most often by the experts, is shown in Table 6 . The presence of at least two criteria or all three criteria performed better than did most of the experts individually (13 and 11 experts, respectively) compared with the CUME reference ( $\mathrm{kappa}=0.77$ and 0.72 ). The proportion, among the 100 datasets, of diagnoses of $\mathrm{T}$-shaped uterus by several individual experts was significantly different from the proportion determined using the CUME reference ( $\mathrm{McNe}$ mar test, $P<0.05$ ), while combination of any two or of all three measurements were not significantly different (McNemar test, $P>0.05$ ).

\section{DISCUSSION}

This study illustrates the challenging nature of the diagnosis of T-shaped uterus. The level of agreement between experts asked to distinguish subjectively between $\mathrm{T}$-shaped and not T-shaped uterus based on assessment of a coronal view of the uterus from a 3D ultrasound dataset was moderate $(\mathrm{kappa}=0.43)$ and the agreement was $82 \%$. To our knowledge, this is the first study to define objectively $\mathrm{T}$-shaped uterus. Also, our findings are relevant to establishment of a definition for this morphological variant of normal uterus, including both the uterine cavity lateral indentation criteria addressed herein and previously published fundal internal indentation criteria $(\text { depth }<10 \mathrm{~mm})^{22}$.

We identified three sonographic measurements that had good diagnostic accuracy and fair to moderate interobserver reproducibility: lateral indentation angle $(\mathrm{AUC}=0.95, \mathrm{CCC}=0.62, \mathrm{CoR}=14 \%)$, lateral internal indentation depth $(\mathrm{AUC}=0.92, \mathrm{CCC}=0.82$, $\mathrm{CoR}=26 \%$ ) and $\mathrm{T}$-angle $(\mathrm{AUC}=0.87, \mathrm{CCC}=0.87$, $\mathrm{CoR}=18 \%$ ). Based on these results, we suggest, for the purpose of research and description of uterine morphology in clinical practice, definitions for normal/arcuate uterus, borderline $\mathrm{T}$-shaped uterus and $\mathrm{T}$-shaped uterus (Table 7) and we establish the CUME definition of T-shaped uterus as follows: lateral indentation angle $\leq 130^{\circ}$; lateral internal indentation depth $\geq 7 \mathrm{~mm}$ and T-angle $\leq 40^{\circ}$ (Figures 6, 7 and S1).

With the suggested diagnosis based on three ultrasound measurements, it was possible to achieve better agreement with the diagnosis selected most often by the group of 15

Table 6 Diagnostic accuracy measures and agreement expressed by kappa for diagnoses made by individual experts, or by combinations of three ultrasound measurement criteria, relative to decision made most often among all 15 experts (CUME reference)

\begin{tabular}{|c|c|c|c|c|c|c|c|c|c|c|c|c|c|}
\hline & $\begin{array}{l}T P \\
\text { (n) }\end{array}$ & $\begin{array}{l}F N \\
(\mathrm{n})\end{array}$ & $\begin{array}{l}T N \\
(\mathrm{n})\end{array}$ & $\begin{array}{l}F P \\
(\mathrm{n})\end{array}$ & $\begin{array}{l}\mathrm{OA} \\
(\%)\end{array}$ & $\begin{array}{c}\text { Sens } \\
(\%)\end{array}$ & $\begin{array}{c}\text { Spec } \\
(\%)\end{array}$ & $\begin{array}{c}P P V \\
(\%)\end{array}$ & $\begin{array}{c}N P V \\
(\%)\end{array}$ & $L R+$ & $L R-$ & Kарpa $(95 \%$ CI $)$ & $\mathrm{P}$ \\
\hline Expert 1 & 20 & 0 & 71 & 9 & 91 & 100 & 89 & 69 & 100 & 8.9 & 0.00 & $0.76(0.61-0.90)$ & 0.004 \\
\hline Expert 2 & 14 & 6 & 75 & 5 & 89 & 70 & 94 & 74 & 93 & 11.2 & 0.32 & $0.65(0.46-0.84)$ & 1.00 \\
\hline Expert 3 & 6 & 14 & 80 & 0 & 86 & 30 & 100 & 100 & 85 & $>100$ & 0.70 & $0.41(0.18-0.64)$ & $<0.001$ \\
\hline Expert 4 & 16 & 4 & 79 & 1 & 95 & 80 & 99 & 94 & 95 & 64.0 & 0.20 & $0.83(0.69-0.98)$ & 0.375 \\
\hline Expert 5 & 7 & 13 & 80 & 0 & 87 & 35 & 100 & 100 & 86 & $>100$ & 0.65 & $0.46(0.23-0.69)$ & $<0.001$ \\
\hline Expert 6 & 18 & 2 & 65 & 15 & 83 & 90 & 81 & 55 & 97 & 4.8 & 0.12 & $0.57(0.40-0.75)$ & 0.002 \\
\hline Expert 7 & 17 & 3 & 75 & 5 & 92 & 85 & 94 & 77 & 96 & 13.6 & 0.16 & $0.76(0.60-0.92)$ & 0.727 \\
\hline Expert 8 & 14 & 6 & 77 & 3 & 91 & 70 & 96 & 82 & 93 & 18.7 & 0.31 & $0.70(0.52-0.88)$ & 0.508 \\
\hline Expert 9 & 18 & 2 & 64 & 16 & 82 & 90 & 80 & 53 & 97 & 4.5 & 0.13 & $0.55(0.38-0.73)$ & 0.001 \\
\hline Expert 10 & 20 & 0 & 65 & 15 & 65 & 100 & 81 & 57 & 100 & 5.3 & 0.00 & $0.63(0.48-0.79)$ & $<0.001$ \\
\hline Expert 11 & 14 & 6 & 70 & 10 & 84 & 70 & 88 & 58 & 92 & 5.6 & 0.34 & $0.54(0.34-0.73)$ & 0.454 \\
\hline Expert 12 & 9 & 11 & 75 & 5 & 84 & 45 & 94 & 64 & 87 & 7.2 & 0.59 & $0.44(0.21-0.67)$ & 0.210 \\
\hline Expert 13 & 13 & 7 & 77 & 3 & 90 & 65 & 96 & 81 & 92 & 17.3 & 0.36 & $0.66(0.47-0.85)$ & 0.344 \\
\hline Expert 14 & 5 & 15 & 80 & 0 & 85 & 25 & 100 & 100 & 84 & $>100$ & 0.75 & $0.35(0.12-0.58)$ & $<0.001$ \\
\hline Expert 15 & 20 & 0 & 73 & 7 & 93 & 100 & 91 & 74 & 100 & 11.4 & 0.00 & $0.81(0.67-0.94)$ & 0.016 \\
\hline LI angle & 16 & 4 & 77 & 3 & 93 & 80 & 96 & 84 & 95 & 21.3 & 0.21 & $0.78(0.62-0.93)$ & 1.00 \\
\hline LI depth & 19 & 1 & 62 & 18 & 81 & 95 & 78 & 51 & 98 & 4.2 & 0.06 & $0.55(0.38-0.72)$ & $<0.001$ \\
\hline T-angle & 16 & 4 & 70 & 10 & 86 & 80 & 88 & 62 & 95 & 6.4 & 0.23 & $0.61(0.42-0.79)$ & 0.18 \\
\hline One or more criterion met* & 20 & 0 & 56 & 24 & 76 & 100 & 70 & 45 & 100 & 3.3 & 0.00 & $0.48(0.33-0.64)$ & $<0.001$ \\
\hline Two or more criteria met* & 18 & 2 & 74 & 6 & 92 & 90 & 93 & 75 & 97 & 12.0 & 0.11 & $0.77(0.61-0.92)$ & 0.289 \\
\hline All three criteria met* & 13 & 7 & 79 & 1 & 92 & 65 & 99 & 93 & 92 & 52.0 & 0.35 & $0.72(0.54-0.90)$ & 0.070 \\
\hline
\end{tabular}

Number of uteri $=100$. ${ }^{*}$ Criteria: lateral indentation angle $\leq 130^{\circ}$; lateral indentation depth $\geq 7 \mathrm{~mm} ; \mathrm{T}$-angle $\leq 40^{\circ}$. FN, false negative; FP, false positive; LR+, positive likelihood ratio; LR-, negative likelihood ratio; LI, lateral indentation; NPV, negative predictive value; OA, observed agreement; PPV, positive predictive value; Sens, sensitivity; Spec, specificity; TN, true negative; TP, true positive. 
Table 7 Criteria and definitions proposed by CUME for classification of uterine morphology as normal/arcuate, borderline $\mathrm{T}$-shaped and $\mathrm{T}$-shaped uterus

\begin{tabular}{ll}
\hline Morphology & Number of criteria* \\
\hline Normal/arcuate uterus & None or only one \\
Borderline T-shaped uterus & Only two \\
T-shaped uterus & All three
\end{tabular}

This classification should be applied only when there is no internal fundal indentation $\geq 10 \mathrm{~mm}$ (according to $\mathrm{CUME}^{22}$ ) and there are no other subjectively recognized anomalies. *Criteria: lateral indentation angle $\leq 130^{\circ}$; lateral indentation depth $\geq 7 \mathrm{~mm}$; T-angle $\leq 40^{\circ}$. experts (CUME reference) than did most of the experts individually. Reproducibility of these measurements was only fair to moderate ${ }^{35}$, even though these were well-trained observers. It is, therefore, important to undergo training before employing these measurements. Attempts should be made to develop technical refinements to improve these measurements (for example, by using an average of three measurements or by creation of software for automated measurements).

We may assume, according to Bayes' theorem, that a true-positive diagnosis using specific morphometric criteria reflects with good accuracy the probability of a patient having this morphology. If one of the three

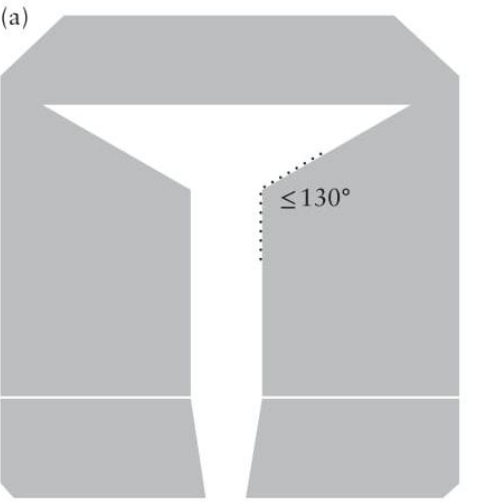

(b)

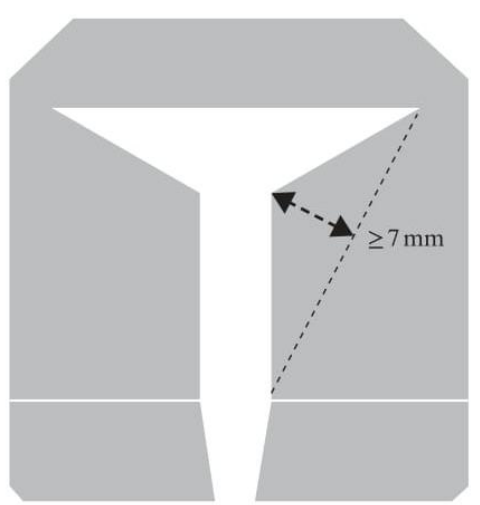

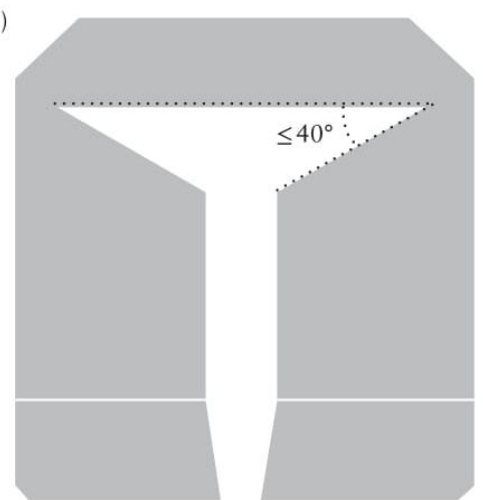

Figure 6 T-shaped uterus as defined by CUME, according to presence of three criteria beyond particular cut-offs: (a) lateral indentation angle $\leq 130^{\circ}$, (b) lateral indentation depth $\geq 7 \mathrm{~mm}$ and (c) T-angle $\leq 40^{\circ}$. Presence of two of these three criteria is defined as borderline T-shaped uterus, whereas lack or presence of only one of these criteria is defined as normal uterus with respect to lateral uterine morphology. This definition is supported by reliability and diagnostic accuracy testing of measurements, and by post-test probability $>90 \%$ for target population, considering diagnosis made most often by experts as reference (i.e. CUME).

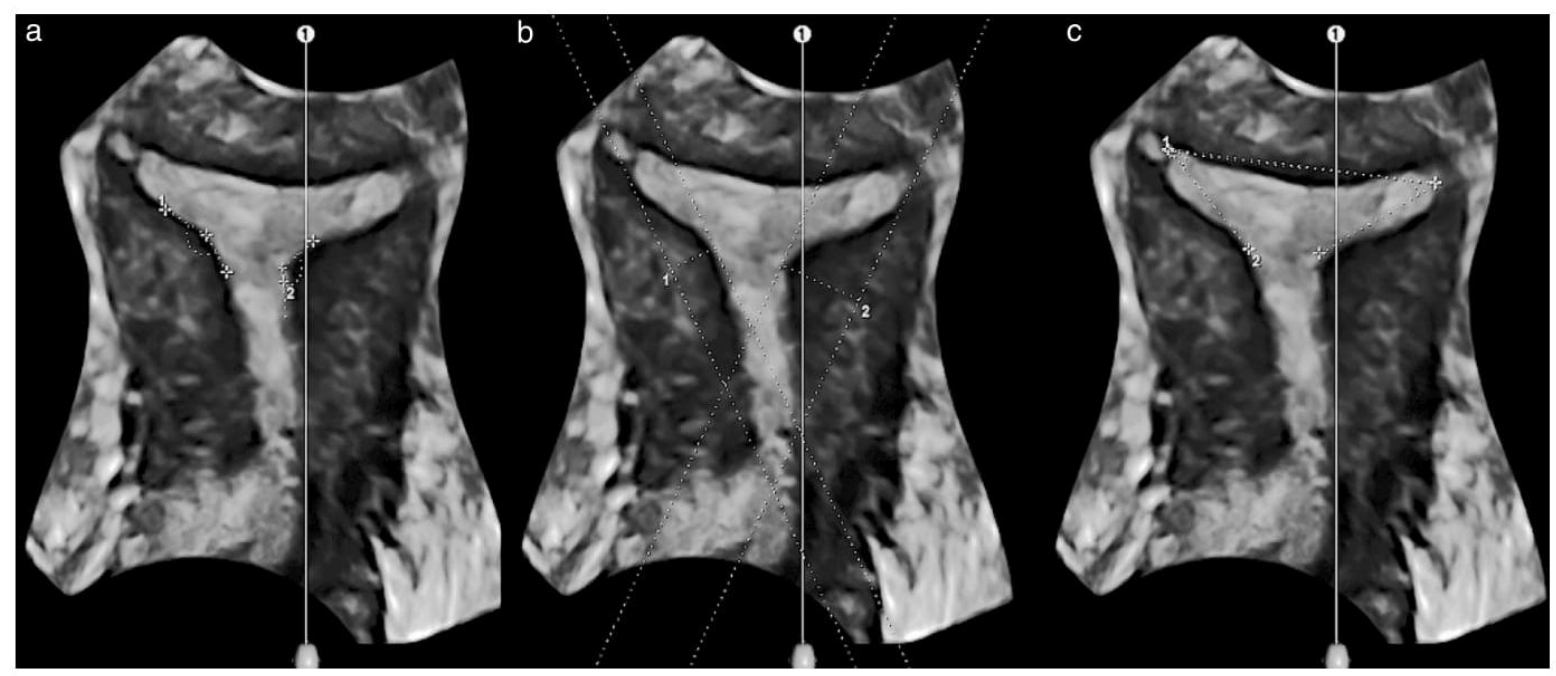

Figure 7 Examples showing performance of proposed three measurements for definition of T-shaped uterus on 3D ultrasound using Omniview with volume contrast imaging: (a) lateral indentation angle (right and left); (b) lateral indentation depth (right and left); and (c) T-angle (right and left) 
ultrasound criteria identified by the CUME process was met, the probability of the woman having a T-shaped uterus was $50-80 \%$, while if none of the three criteria was met, the probability was very low (Figure 5). The post-test probability of T-shaped uterus based on a single criterion identified by CUME should be considered as insufficient for diagnosis. For instance, $50 \%$ of women with internal indentation depth $\geq 7 \mathrm{~mm}$ and therefore suspected of having a T-shaped uterus will in fact have a T-shaped uterus and $50 \%$ will have a normal uterus. If, for example, these women are included in a surgical randomized controlled trial, both women with T-shaped uterus and those with normal uterus would be treated. Any benefit of the intervention for women with a T-shaped uterus may go undetected, and women with a normal uterus may receive iatrogenic treatment. Moreover, in our sample, $2 / 20(10 \%)$ women, $5 / 10(50 \%)$ women and $13 / 14(93 \%)$ women who met one criterion, two criteria and all three criteria, respectively, actually had T-shaped uterus according to CUME. Based on these study results regarding the ultrasound criteria identified by CUME, we suggest in Table 7 definitions for normal/arcuate uterus, borderline T-shaped uterus and T-shaped uterus. Of note, using our suggested definition for T-shaped uterus based on three sonographic measurements, it is possible to achieve better agreement with the CUME reference, based on the decision made most often by 15 experts, than did most of the experts individually (Table 6).

There are some important limitations of this study. (i) Although this study was able to define objective measurable criteria to diagnose T-shaped uterus, with moderate agreement according to multiexpert opinion, the clinical relevance of the non-DES-related T-shaped uterus is unknown. (ii) Measurements were performed by highly trained observers, and using a single 3D ultrasound dataset for each uterus; this may not reflect what happens in clinical reality, in which many sources of variability are present, which may have a negative impact on the accuracy and reliability of diagnoses of uterine anomalies. (iii) We used only datasets with lateral indentation detected subjectively, yet detection of all small lateral indentations by measurement may be more accurate and reliable. (iv) We used only datasets with no other subjectively detected anomaly, which means that the CUME criteria were not tested with other defined or undefined minor or major anomalies, or other variants of normal uterus with respect to uterine cavity shape, size and symmetry. (v) Assessment of the uterus and uterine cavity was limited to the mid-coronal plane, which is flat, whereas assessment of $3 \mathrm{D}$ spatial morphology and uterine cavity volume, and their quantification, could be important for a modern classification of uterine morphology ${ }^{36}$. (vi) For the lateral indentation depth, the internal os was used as a reference point, but this may sometimes be difficult to determine. The observed results should not, therefore, be generalized for screening purposes or for assessing other uterine variants, despite our sample representing a wide spectrum of uteri that may be considered as normal/arcuate uteri by the ASRM classification, and normal but misleadingly labeled as septate uteri by the ESHRE/ESGE classification ${ }^{11,22,37}$.
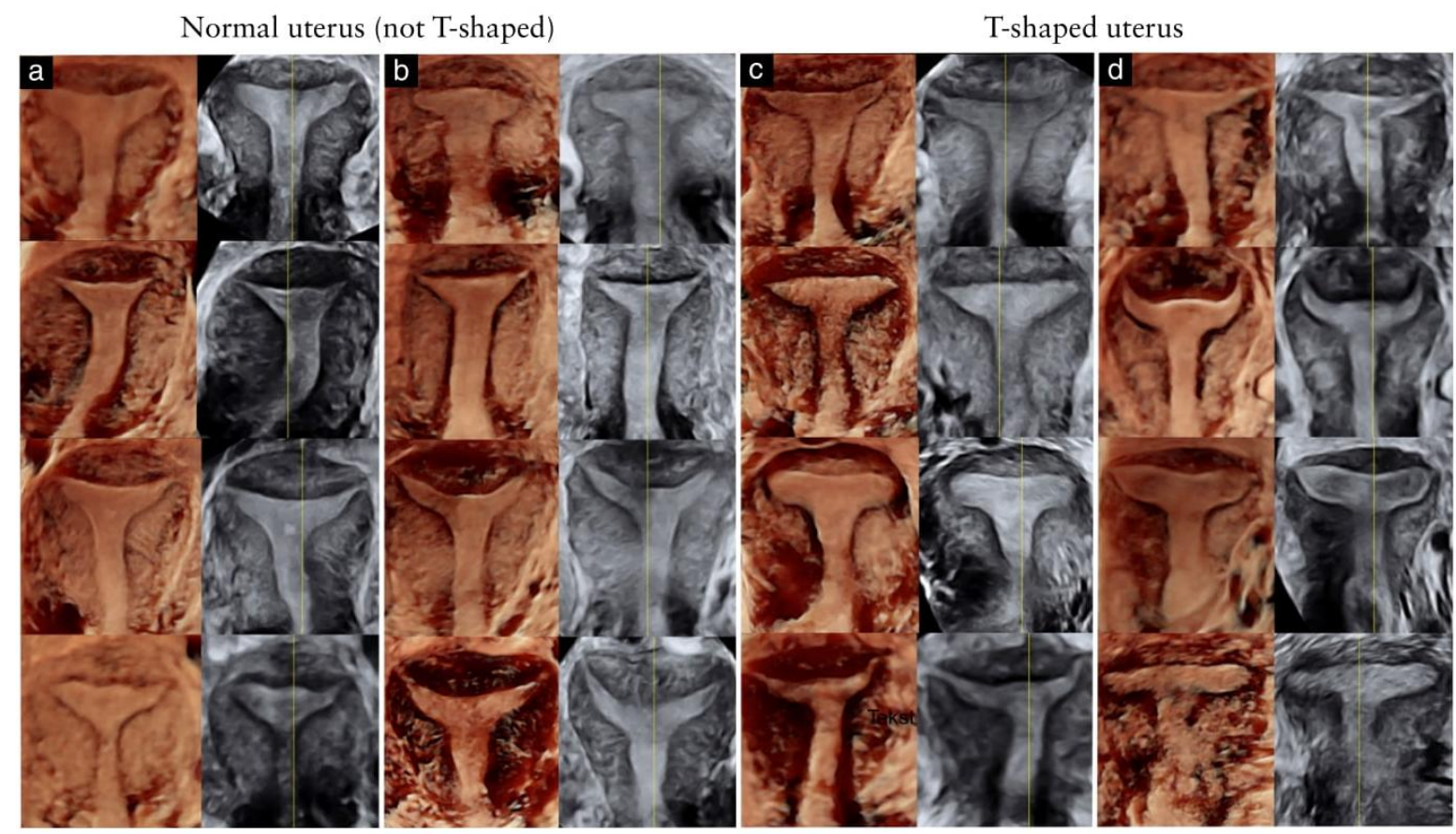

Figure 8 Examples of uteri indicating for each the diagnosis made most often by experts, and illustrating recognition of normal (a,b) and T-shaped (c,d) uterus, with very good (12-15 of 15 experts made this diagnosis; (a,d)) and good (8-11 of 15 made this diagnosis; (b,c)) agreement, with decreasing numbers of decisions for normal uterus from top to bottom. 
The decision to include particular cases might have led to some selection bias.

This study may make an important contribution to the development of a common language for uterine morphology and in the further development of a single, global classification system, with unification of the criteria of various different, more local, classifications, such as those of ESHRE-ESGE and ASRM. Moreover, our results may help in understanding and validating the quality of evidence on T-shaped uterus, and may help to improve the quality of studies and our understanding of this morphology. It may well be that non-DES-related T-shaped uterus is not a congenital anomaly and need not be treated as such. Further efforts should be aimed at determining whether T-shaped uterus is a true uterine anomaly with clinical consequences.

The reliability of all studies regarding prevalence, clinical implications and surgical outcome of $\mathrm{T}$-shaped uterus may be interpreted in the context of this CUME study. So far, the diagnosis has been only subjective. However, our study has shown that the agreement, even among experts, of subjective judgments is not very high (Figure 8). An ideal solution would be to obtain a subjective judgment from several experts, but this is impractical in clinical practice. Our proposed CUME criteria might be used as a surrogate for multiexpert opinion to achieve similar results, with better accuracy and agreement with the reference than is achieved by the subjective judgement of most individual experts.

The definition of $\mathrm{T}$-shaped uterus proposed by ESHRE/ESGE, a 'narrow uterine cavity due to thickened lateral walls with a correlation $2 / 3$ uterine corpus and $1 / 3$ cervix $^{\prime 19}$ is arbitrary and was not based on scientific support. By using this definition, it is impossible to differentiate $\mathrm{T}$-shaped uterus from normal uterus and from uterus infantilis, because the reference value of normal uterine-wall thickness and any cut-offs for differentiation of $\mathrm{T}$-shaped uterus from other uterine morphologies were not provided. Interestingly, the ESHRE/ESGE definition has been used retrospectively in some studies ${ }^{12,17,38}$; however, its application in clinical practice to differentiate between $\mathrm{T}$-shaped uterus and normal uterus is impossible. Before the ESHRE-ESGE classification, T-shaped uterus was recognized according to DES etiology and subjective impression, by the AFS-1988 classification ${ }^{8,11}$.

Using our results, it should be much easier to study the prevalence of $\mathrm{T}$-shaped uterus and assess its clinical relevance. Until such studies are available, it is suggested not to treat $\mathrm{T}$-shaped uterus as an anomaly, but as a variant of normal uterus, to avoid unnecessary intervention in infertile women or in women with previous miscarriage. Such studies are important in the current era when there is perhaps a tendency towards over-definition of diseases ${ }^{39}$ and offering 'add-on' intervention to fertility treatment.

In conclusion, the diagnosis of T-shaped uterus is not easy; the agreement among experts was only moderate and the judgment of individual experts was commonly insufficient for accurate diagnosis. In this study we have identified three ultrasound measurements, with cut-offs, that had good diagnostic test accuracy and fair to moderate reliability (lateral internal indentation depth $\geq 7 \mathrm{~mm}$, lateral indentation angle $\leq 130^{\circ}$ and $\mathrm{T}$-angle $\leq 40^{\circ}$ ) and, when applied in combination, they provided high post-test probability for T-shaped uterus. These three CUME criteria for defining T-shaped uterus may aid in determination of the prevalence, clinical implications, best management of women with this morphology and assessment of post-surgical morphologic outcome with sufficient accuracy and reliability and with a known probability of disease following negative and positive test results. The CUME definition of T-shaped uterus may help in the development of interventional randomized controlled trials and observational studies and in the diagnosis of uterine morphology in everyday practice, and could be adopted by guidelines on uterine anomalies to enrich their classification systems.

\section{ACKNOWLEDGMENTS}

We thank Marzena Stryjak (Ludwin \& Ludwin Gynecology, Krakow, Poland) for her help in data management. This study was supported by Jagiellonian University (grant no. K/ZDS/005568).

\section{REFERENCES}

1. Schultze GKF, Erbsloh J. Gynakologische Rontgendiagnostik: Ferdinand Enke: Stuttgart, 1954.

. Erbsloeh J. Normal shapes, variations and malformations in hysterosalpingography. Radiologe 1975; 15: 2-10.

3. Kaufman RH, Adam E. Genital tract anomalies associated with in utero exposure to diethylstilbestrol. Isr I Med Sci 1978; 14: 353-362.

4. Kaufman RH, Binder GL, Gray PM, Jr., Adam E. Upper genital tract changes associated with exposure in utero to diethylstilbestrol. Obstet Gynecol Surv 1977; 32: 611-613.

5. Acien P, Acien MI. The history of female genital tract malformation classifications and proposal of an updated system. Hum Reprod Update 2011; 17: 693-705.

6. Buttram VC, Jr., Gibbons WE. Mullerian anomalies: a proposed classification. (Ar analysis of 144 cases). Fertil Steril 1979; 32: 40-46.

7. Fernandez H, Garbin O, Castaigne V, Gervaise A, Levaillant JM. Surgical approach to and reproductive outcome after surgical correction of a T-shaped uterus. Hum Reprod 2011; 26: 1730-1734.

8. AFS. The American Fertility Society classifications of adnexal adhesions, distal tubal occlusion, tubal occlusion secondary to tubal ligation, tubal pregnancies, mullerian acciusion, tubal occlusion secondary to tubal ligation, tubal pregnancies,

9. Al Jishi T, Sergi C. Current perspective of diethylstilbestrol (DES) exposure in mothers and offspring. Reprod Toxicol 2017; 71: 71-77.

10. van Gils AP, Tham RT, Falke TH, Peters AA. Abnormalities of the uterus and cervix after diethylstilbestrol exposure: correlation of findings on MR and hysterosalpingography. AJR Am J Roentgenol 1989; 153: 1235-1238.

11. Ludwin A, Ludwin I. Comparison of the ESHRE-ESGE and ASRM classifications of Mullerian duct anomalies in everyday practice. Hum Reprod 2015; 30: 569-580.

12. Di Spiezio Sardo A, Florio P, Nazzaro G, Spinelli M, Paladini D, Di Carlo C, Nappi C Hysteroscopic outpatient metroplasty to expand dysmorphic uteri (HOME-DU technique): a pilot study. Reprod Biomed Online 2015; 30: 166-174.

13. Ahmadi F, Zafarani F, Shahrzad GS. Hysterosalpingographic Appearances of Female Genital Tract Tuberculosis: Part II: Uterus. Int J Fertil Steril 2014; 8: 13-20.

14. Puente JM, Fabris A, Patel J, Patel A, Cerrillo M, Requena A, Garcia-Velasco JA Adenomyosis in infertile women: prevalence and the role of $3 \mathrm{D}$ ultrasound as a marker of severity of the disease. Reprod Biol Endocrinol 2016; 14: 60.

15. Barranger E, Gervaise A, Doumerc S, Fernandez H. Reproductive performance after hysteroscopic metroplasty in the hypoplastic uterus: A study of 29 cases. BJOG 2002; 109: 1331-1334

16. Boza A, Akin OD, Oguz SY, Misirlioglu S, Urman B. Surgical correction of T-shaped uteri in women with reproductive failure: Long term anatomical and reproductive outcomes. J Gynecol Obstet Hum Reprod 2019; 48: 39-44.

17. Ducellier-Azzola G, Lecointre L, Hummel M, Pontvianne M, Garbin O Hysteroscopic enlargement metroplasty for T-shaped uterus: 24 years' experience at the Strasbourg Medico-Surgical and Obstetrical Centre (CMCO). Fur J Obstet Gynecol Reprod Biol 2018; 226: 30-34. 
18. Sukur YE, Yakistiran B, Ozmen B, Sonmezer M, Berker B, Atabekoglu C. Hysteroscopic Corrections for Complete Septate and T-Shaped Uteri Have Similar Surgical and Reproductive Outcome. Reprod Sci 2018; 25: 1649-1654.

19. Grimbizis GF, Gordts S, Di Spiezio Sardo A, Brucker S, De Angelis C, Gergolet M, Li TC, Tanos V, Brolmann H, Gianaroli L, Campo R. The ESHRE/ESGE consensus on the classification of female genital tract congenital anomalies. Hum Reprod 2013; 28: 2032-2044.

20. Salim R, Woelfer B, Backos M, Regan L, Jurkovic D. Reproducibility of three-dimensional ultrasound diagnosis of congenital uterine anomalies. Ultrasound Obstet Gynecol 2003; 21: 578-582.

21. Practice Committee of the American Society for Reproductive Medicine. Uterine Practice Committee of the American Society for Reprod
septum: a guideline. Fertil Steril 2016; 106: 530-540.

22. Ludwin A, Martins WP, Nastri CO, Ludwin I, Coelho Neto MA, Leitao VM, Acien M, Alcazar JL, Benacerraf B, Condous G, De Wilde RL, Emanuel MH, Gibbons W, Guerriero S, Hurd WW, etal. Congenital Uterine Malformation by Experts (CUME): better criteria for distinguishing between normal/arcuate and septate uterus? Ultrasound Obstet Gynecol 2018; 51: 101-109.

23. Kottner J, Audigé L, Brorson S, Donner A, Gajeweski BJ, Hróbjartsson A, Robersts C, Shoukri M, Streiner DL. Guidelines for reporting reliability and agreement studies (GRRAS) were proposed. J Clin Epidemiol 2011; 64: 96-106.

24. von Elm E, Altman DG, Egger M, Pocock SJ, Gøtzsche PC, Vandenbroucke JP; STROBE Initiative. The Strengthening the Reporting of Observational Studies in Epidemiology (STROBE)statement: guidelines for reporting observational studies. J Clin Epidemiol 2008; 61: 344-349.

25. Cocchetti DV. Sample size requirements for increasing the precision of reliability estimates: problems and proposed solutions. J Clin Exp Neuropsychol 1999; 21: 567-570.

26. Donner A, Rotondi MA. Sample size requirements for interval estimation of the kappa statistic for interobserver agreement studies with a binary outcome and multiple raters. Int J Biostat 2010; 6: Article 31.

27. Cicchetti DV. The precision of reliability and validity estimates re-visited. distinguishing between clinical and statistical significance of sample size requirements. J Clin Exp Neuropsychol 2001; 23: 695-700.
28. Jouannic JM, Rosenblatt J, Demaria F, Jacobs R, Aubry MC, Benifla JL. Contribution of three-dimensional volume contrast imaging to the sonographic assessment of the fetal uterus. Ultrasound Obstet Gynecol 2005; 26: 567-570.

29. Kagan KO, Pintoffl K, Hoopmann M. First-trimester ultrasound images using HDlive. Ultrasound Obstet Gynecol 2011; 38: 607.

30. Ludwin A, Ludwin I, Coelho Neto MA, Nastri CO, Bhagavath B, Lindheim SR, Martins WP. Septate uterus by updated ESHRE/ESGE, ASRM and CUME definitions: Martin W. S Sul in healthcare systems. Ultrasound Obstet Gynecol 2019;54: 800-814.

31. Fagan TJ. Letter: Nomogram for Bayes theorem. N Engl J Med 1975; 293: 257.

32. Glasziou P. Which methods for bedside Bayes? BMJ Evid Based Med 2001; 6: $164-166$.

33. Caraguel CG, Vanderstichel R. The two-step Fagan's nomogram: ad hoc interpretation of a diagnostic test result without calculation. Evid Based Med 2013; 18: $125-128$.

34. Kottner J, Gajewski BJ, Streiner DL. Guidelines for Reporting Reliability and Agreement Studies (GRRAS). Int J Nurs Stud 2011; 48: 659-660.

35. Martins WP, Nastri CO. Interpreting reproducibility results for ultrasound measurements. Ultrasound Obstet Gynecol 2014; 43: 479-480.

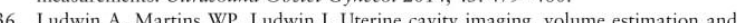
quantification of degree of deformity using automatic volume calculation: description quantification of degree of deformity using automatic volume ca

37. Knez J, Saridogan E, Van Den Bosch T, Mavrelos D, Ambler G, Jurkovic D. ESHRE/ESGE female genital tract anomalies classification system-the potential impact of discarding arcuate uterus on clinical practice. Hum Reprod 2018; 33: 600-606.

38. De Bruyn C, Greet M, Willem O, Rudi C. The impact of hysteroscopic surgery for dysmorphic uterus on reproductive and obstetric outcomes: Pilot study, Gynecological Surgery 2013; 10: S101-S102.

39. Brodersen J, Schwartz LM, Heneghan C, O'Sullivan JW, Aronson JK, Woloshin S. Overdiagnosis: what it is and what it isn't. BMJ Evid Based Med 2018; 23: $1-3$.

\section{SUPPORTING INFORMATION ON THE INTERNET}

The following supporting information may be found in the online version of this article:

Figure S1 Examples of three sonographic measurements to diagnose T-shaped uterus in variants of uterus with lateral indentations: (a) with concomitant small fundal indentation, (b) with cornua of uterine cavity above top of cavity and (c) with cornua of uterine cavity below top of cavity. Measurements illustrated are T-angle (top row), lateral indentation depth (middle row) and lateral indentation angle (bottom row).

Table S1 Details of CUME group for T-shaped uterus reference and observers performing ultrasound measurements to establish objective diagnostic criteria for T-shaped uterus

Table S2 Results of all 15 potentially useful ultrasound measurements performed by two different observers to establish objective diagnostic criteria for T-shaped uterus

Table S3 Interobserver reliability/agreement for all potentially useful ultrasound measurements tested to establish objective diagnostic criteria for T-shaped uterus

Table S4 Diagnostic test accuracy of all potentially useful ultrasound measurements tested to establish objective diagnostic criteria for T-shaped uterus

Table S5 T-shaped uterus according to best cut-off values for selected measurements and their agreement with multiexpert opinion (reference standard) 
(a)

T-angle

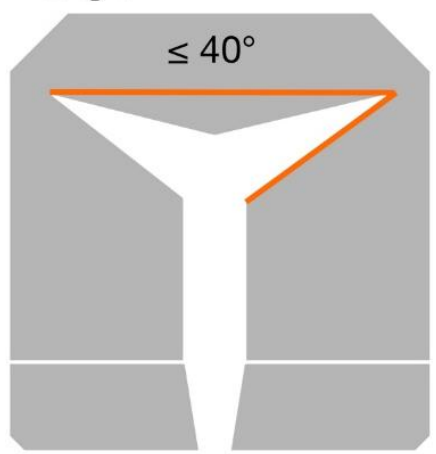

Lateral depth

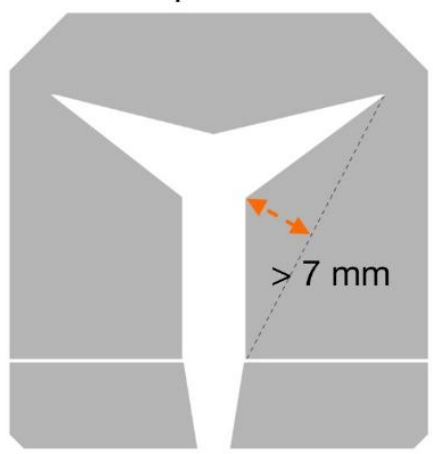

Lateral angle

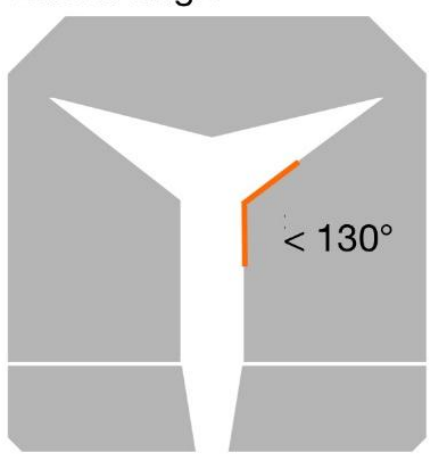

(b)
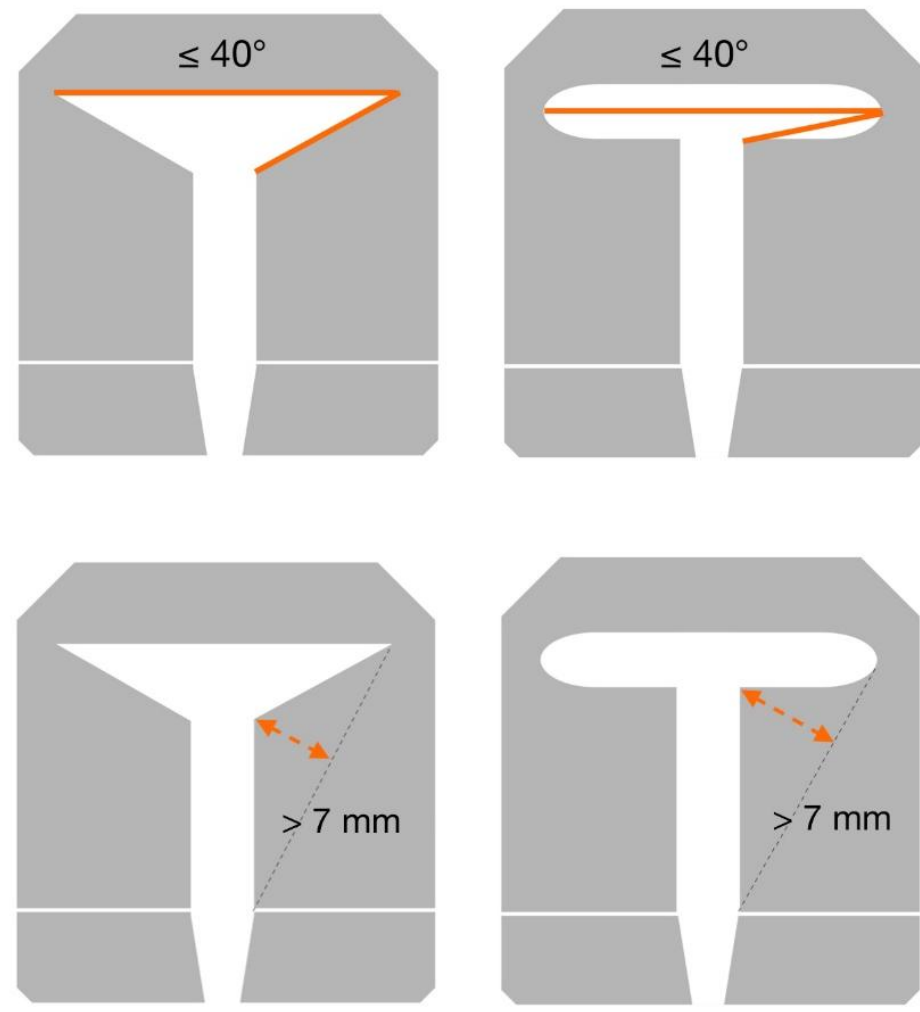

(c)
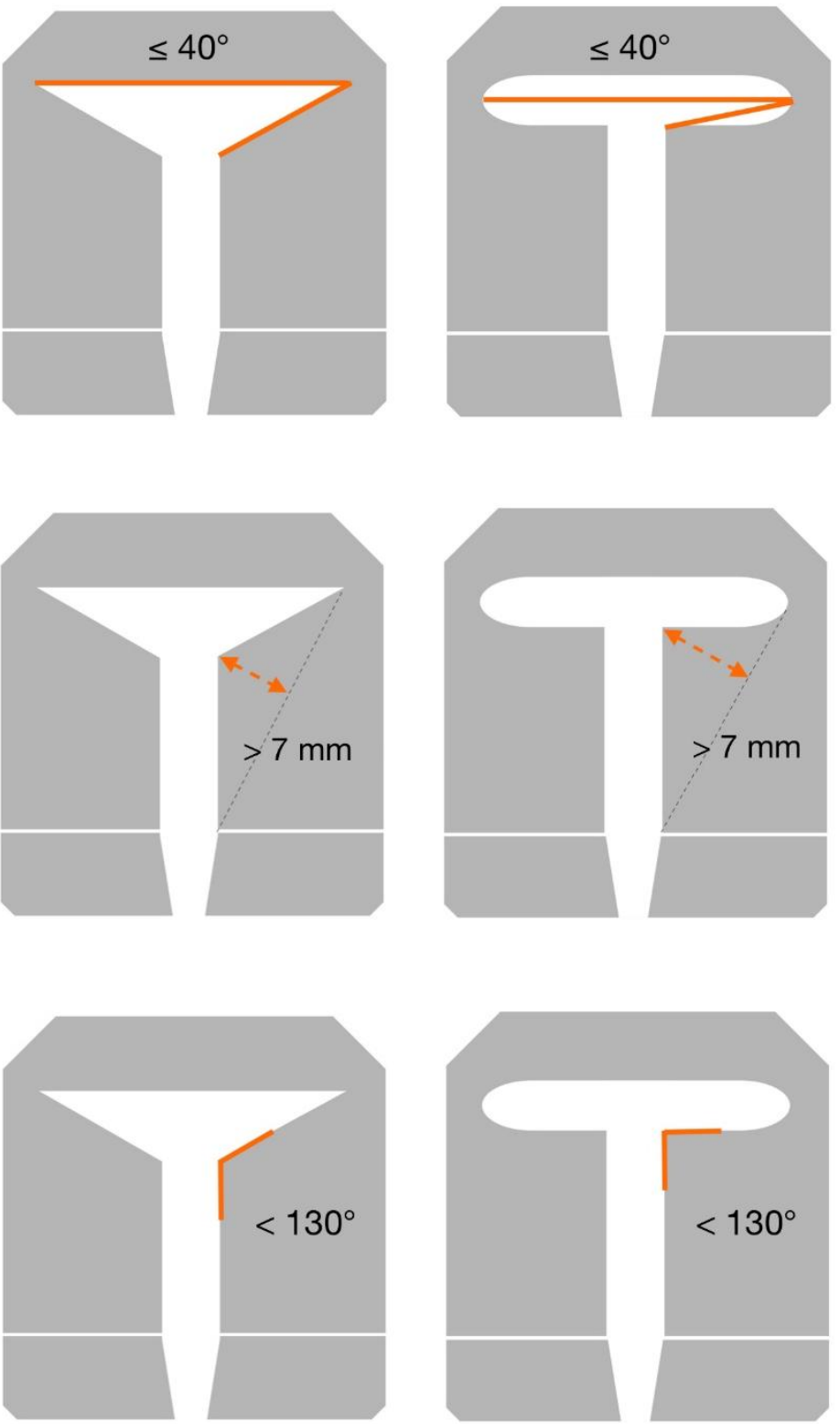

Figure S1 - Examples of three sonographic measurements to diagnose T-shaped uterus in variants of uterus with lateral indentations: (a) with concomitant small fundal indentation, (b) with cornues of uterine cavity on top of cavity and (c) with cornues of uterine cavity below top of cavity. Measurements illustrated are T-angle (top row), lateral indentation depth (middle row) and lateral indentation angle (bottom row). 
Table S1 - Details of CUME group for T-shaped uterus reference and observers performing ultrasound measurements to establish objective diagnostic criteria for T-shaped uterus

\begin{tabular}{lccc}
\hline \multicolumn{1}{c}{ Expert } & $\begin{array}{c}\text { Country of } \\
\text { residence }\end{array}$ & $\begin{array}{c}\text { Main affiliation - } \\
\text { International Society }\end{array}$ & $\begin{array}{c}\text { Years of } \\
\text { experience }\end{array}$ \\
\hline Clinicians & Spain & ESHRE & \\
M. Acién & USA & ASRM & 14 years \\
A. DeCherney & USA & ACOG & 45 years \\
W. Hurd & Spain & ASRM & 39 years \\
A. Pellicer & Italy & ESHRE & 28 years \\
F. Petraglia & & & 34 years \\
\hline Surgeons & ESGE & \\
M. H. Emanuel & Thetherlands & ESGE & 31 years \\
M. P. Diamond & USA & AAGL & 32 years \\
S. Lindheim & USA & ASRM & 25 years \\
E. Saridogan & UK & ESGE & 31 years \\
R-L. de Wilde & Germany & ESGE & 36 years \\
\hline Sonologists & & & 25 years \\
J. L. Alcazar & Spain & ISUOG & 41 years \\
B. Benacerraf & USA & AIUM & 18 years \\
G. Condous & Australia & ASUM & 31 years \\
S. Guerriero & Italy & ISUOG & 22 years \\
D. Levine & USA & RSNA &
\end{tabular}

Raters who performed measurements/acquisitions
A. Ludwin
Poland
ISUOG
19 years
I. Ludwin
Poland
ISUOG
16 years
W. P. Martins
Brazil
ISUOG
16 years

AAGL= American Association of Gynecologic Laparoscopists; ACOG= American College of Obstetricians and Gynecologists; AlUM= American Institute of Ultrasound in Medicine; ASRM= American Society for Reproductive Medicine; ASUM= Australasian Society for Ultrasound in Medicine; ESGE= European Society for Gynaecological Endoscopy; ESHRE= European Society of Human Reproduction and Embryology; ISUOG= International Society of Ultrasound in Obstetrics and Gynecology; RSNA= Radiological Society of North America. 
Table S2 - Results of all 15 potentially useful ultrasound measurements performed by two different observers to establish objective diagnostic criteria for T-shaped uterus

\begin{tabular}{|c|c|c|c|c|c|c|c|c|c|c|c|c|c|c|}
\hline & \multicolumn{7}{|c|}{ Observer 1: A.L. } & \multicolumn{7}{|c|}{ Observer 2: W.M.P. } \\
\hline Measurement & Median & \multicolumn{2}{|c|}{ Q1-Q3 } & \multicolumn{2}{|c|}{ Min-Max } & \multirow{2}{*}{$\begin{array}{c}\text { Mean } \\
6.7\end{array}$} & \multirow{2}{*}{$\begin{array}{l}\text { SD } \\
1.7\end{array}$} & \multirow{2}{*}{$\begin{array}{c}\text { Median } \\
5.9\end{array}$} & \multicolumn{2}{|c|}{ Q1-Q3 } & \multicolumn{2}{|c|}{ Min-Max } & \multirow{2}{*}{$\begin{array}{c}\text { Mean } \\
6.2\end{array}$} & \multirow{2}{*}{$\frac{\mathrm{SD}}{1.6}$} \\
\hline Lateral internal indentation depth (mm) & 6.5 & 5.5 & 8 & 3.5 & 11.1 & & & & 5 & 7.3 & 2.9 & 11.5 & & \\
\hline Circle area of uterine cavity $\left(\mathrm{cm}^{2}\right)$ & 17.2 & 14.2 & 20.6 & 8.8 & 33.9 & 17.3 & 4.8 & 17 & 14.2 & 19.8 & 8.6 & 37.7 & 17.2 & 4.6 \\
\hline Uterine cavity area $\left(\mathrm{cm}^{2}\right)$ & 5.5 & 4.7 & 6.5 & 2.9 & 10.3 & 5.6 & 1.5 & 5.4 & 4.5 & 6.3 & 2.7 & 10.5 & 5.4 & 1.5 \\
\hline Uterine cavity circumference $(\mathrm{cm})$ & 13.3 & 12.1 & 14.5 & 9.4 & 18.9 & 13.3 & 1.8 & 12.9 & 12 & 14 & 8.9 & 19.8 & 13.1 & 1.8 \\
\hline Uterine cavity length (mm) & 37.6 & 33.1 & 41.6 & 26.8 & 54.3 & 37.7 & 5.6 & 38.1 & 34.6 & 42.6 & 22.8 & 54 & 38.6 & 6 \\
\hline Uterine cavity width (mm) & 37.2 & 33.1 & 41.5 & 23.4 & 60.2 & 37.6 & 6.5 & 36.2 & 32 & 40.3 & 22.7 & 60.9 & 36.1 & 6.2 \\
\hline Fundal internal indentation angle (degrees) & 169 & 156 & 175 & 134 & 214 & 167.6 & 16.5 & 158 & 151 & 170 & 123 & 213 & 160.9 & 16.9 \\
\hline Lateral indentation angle: right (degrees) & 137 & 126 & 146 & 93 & 171 & 136.1 & 15.2 & 141 & 131 & 150 & 97 & 165 & 139.5 & 14 \\
\hline Lateral indentation angle: left (degrees) & 142 & 134 & 151 & 89 & 168 & 141.4 & 12.9 & 140 & 131 & 147 & 105 & 157 & 138.1 & 11.6 \\
\hline Lateral indentation angle: average (degrees) & 139 & 133 & 147 & 98 & 160 & 138.7 & 11.6 & 141 & 134 & 146 & 101 & 160 & 138.8 & 10.6 \\
\hline Cornual angle: right (degrees) & 63 & 52.4 & 75.8 & 34.3 & 114.9 & 65.4 & 18.1 & 53 & 44 & 63.7 & 28.1 & 96.6 & 54.1 & 14.4 \\
\hline Cornual angle: left (degrees) & 59.9 & 48 & 73.7 & 31 & 119.4 & 61.2 & 16.9 & 52.7 & 43.5 & 62.2 & 29.9 & 89.2 & 53.8 & 13.1 \\
\hline Cornual angle: average (degrees) & 62.3 & 50.3 & 74.9 & 33.7 & 98.3 & 63.3 & 16 & 53 & 45.2 & 64.1 & 29.7 & 92.9 & 53.9 & 12.9 \\
\hline T-angle: right (degrees) & 45.7 & 38.5 & 51.4 & 19 & 65.1 & 45.3 & 8.4 & 47.2 & 39.8 & 54.1 & 19.8 & 66.8 & 47.4 & 9.6 \\
\hline T-angle: left (degrees) & 45.5 & 41.7 & 54.2 & 24.8 & 73.2 & 47.7 & 9.9 & 48.3 & 43.6 & 55.2 & 20.8 & 68.5 & 48 & 9.1 \\
\hline T-angle: average (degrees) & 46.7 & 40.9 & 51.4 & 22 & 63.5 & 46.5 & 8.3 & 47.9 & 42.1 & 53.3 & 20.3 & 63.6 & 47.7 & 8.6 \\
\hline Uterine cavity area/uterine cavity circle area & 0.32 & 0.29 & 0.36 & 0.23 & 0.51 & 0.33 & 0.05 & 0.31 & 0.28 & 0.36 & 0.21 & 0.47 & 0.32 & 0.05 \\
\hline Uterine cavity area/uterine cavity circumference & 0.42 & 0.35 & 0.47 & 0.28 & 0.59 & 0.41 & 0.07 & 0.41 & 0.36 & 0.45 & 0.26 & 0.61 & 0.41 & 0.07 \\
\hline $\begin{array}{l}\text { Uterine cavity area/uterine cavity } \\
\text { circumference }^{2}\end{array}$ & 0.03 & 0.03 & 0.03 & 0.02 & 0.05 & 0.03 & 0 & 0.03 & 0.03 & 0.04 & 0.02 & 0.05 & 0.03 & 0 \\
\hline
\end{tabular}

n= 100 uteri; Q1-Q3= lower-upper quartile. 
Table S3 - Interobserver reliability/agreement for all 15 potentially useful ultrasound measurements tested to establish objective diagnostic criteria for T-shaped uterus

\begin{tabular}{|c|c|c|c|c|c|c|c|c|}
\hline \multirow[b]{2}{*}{ Fundal internal indentation depth (mm) } & \multirow{2}{*}{$\begin{array}{c}\text { MD } \\
-0.13\end{array}$} & \multirow{2}{*}{$\begin{array}{c}\text { SD } \\
1.00\end{array}$} & \multicolumn{2}{|c|}{ LoA } & \multirow{2}{*}{$\begin{array}{c}\text { CoR } \\
1.95\end{array}$} & \multirow{2}{*}{$\begin{array}{l}\text { CCC } \\
0.91\end{array}$} & \multicolumn{2}{|c|}{$95 \% \mathrm{Cl}$} \\
\hline & & & -2.09 & 1.82 & & & 0.87 & 0.94 \\
\hline Right lateral internal indentation depth ( $\mathrm{mm}$ ) & 0.44 & 1.43 & -2.36 & 3.25 & 2.81 & 0.78 & 0.69 & 0.84 \\
\hline Left lateral internal indentation depth $(\mathrm{mm})$ & 0.64 & 1.06 & -1.44 & 2.71 & 2.08 & 0.83 & 0.76 & 0.88 \\
\hline Circle area of uterine cavity $\left(\mathrm{cm}^{2}\right)$ & 0.13 & 2.17 & -4.13 & 4.38 & 4.25 & 0.90 & 0.85 & 0.93 \\
\hline Uterine cavity area $\left(\mathrm{cm}^{2}\right)$ & 0.17 & 0.40 & -0.62 & 0.96 & 0.79 & 0.96 & 0.94 & 0.97 \\
\hline Uterine cavity circumference $(\mathbf{c m})$ & 0.24 & 0.76 & -1.26 & 1.73 & 1.50 & 0.90 & 0.85 & 0.93 \\
\hline Uterine cavity length (mm) & -0.88 & 3.24 & -7.23 & 5.48 & 6.35 & 0.84 & 0.77 & 0.89 \\
\hline Uterine cavity width (mm) & 1.47 & 2.15 & -2.75 & 5.68 & 4.22 & 0.92 & 0.88 & 0.94 \\
\hline Fundal indentation angle (degrees) & 6.78 & 12.55 & -17.82 & 31.38 & 24.60 & 0.66 & 0.55 & 0.75 \\
\hline Right lateral indentation angle (degrees) & -3.43 & 11.32 & -25.62 & 18.77 & 22.19 & 0.68 & 0.57 & 0.77 \\
\hline Left lateral indentation angle (degrees) & 3.24 & 13.24 & -22.71 & 29.19 & 25.95 & 0.41 & 0.24 & 0.55 \\
\hline Right cornual angle (degrees) & 11.34 & 13.84 & -15.80 & 38.47 & 27.13 & 0.52 & 0.39 & 0.62 \\
\hline Left cornual angle (degrees) & 7.40 & 11.87 & -15.86 & 30.66 & 23.27 & 0.62 & 0.50 & 0.71 \\
\hline Right T-angle (degrees) & -2.12 & 5.16 & -12.22 & 7.98 & 10.10 & 0.82 & 0.74 & 0.87 \\
\hline Left T-angle (degrees) & -0.33 & 5.59 & -11.29 & 10.64 & 10.96 & 0.83 & 0.75 & 0.88 \\
\hline Uterine cavity area / uterine cavity circle area & 0.010 & 0.034 & -0.056 & 0.076 & 0.07 & 0.77 & 0.68 & 0.84 \\
\hline Uterine cavity area / uterine cavity circumference & 0.006 & 0.023 & -0.039 & 0.050 & 0.045 & 0.95 & 0.92 & 0.96 \\
\hline Uterine cavity area / uterine cavity circumference ${ }^{2}$ & $<0.001$ & 0.003 & -0.006 & 0.006 & 0.006 & 0.84 & 0.76 & 0.89 \\
\hline Lateral internal indentation depth average (mm) & 0.59 & 0.82 & -1.02 & 2.20 & 1.61 & 0.82 & 0.75 & 0.87 \\
\hline Lateral internal indentation angle average $(\mathrm{mm})$ & -0.10 & 9.72 & -19.15 & 18.95 & 19.05 & 0.62 & 0.48 & 0.73 \\
\hline Cornual angle average (degrees) & 9.37 & 10.67 & -11.55 & 30.28 & 20.91 & 0.60 & 0.49 & 0.69 \\
\hline T-angle average (degrees) & -1.23 & 4.13 & -9.33 & 6.87 & 8.10 & 0.87 & 0.82 & 0.91 \\
\hline
\end{tabular}

$\mathbf{n}=100$ uteri, MD= mean difference; LoA= limits of agreement; CoR= Coefficient of Repeatability; $\mathbf{C C C}=$ Concordance correlation coefficient, $\mathbf{C l}=$ Confidence interval. 
Table S4 - Diagnostic test accuracy of all 15 potentially useful ultrasound measurements tested to establish objective diagnostic criteria for T-shaped uterus

\begin{tabular}{lcccc}
\hline & \multicolumn{2}{c}{ Area Under the Curve } & $\begin{array}{c}\text { Correlation with sum of } \\
\text { diagnoses }\end{array}$ \\
& Area & \multicolumn{2}{c}{$95 \%$ Cl } & $\begin{array}{c}\text { Spearman correlation } \\
\text { coefficient }\end{array}$ \\
\hline Fundal internal indentation depth & 0.55 & 0.41 & 0.70 & -0.01 \\
Right lateral internal indentation depth & 0.86 & 0.78 & 0.94 & 0.57 \\
Left lateral internal indentation depth & 0.80 & 0.68 & 0.92 & 0.43 \\
Lateral internal indentation depth average & 0.92 & 0.87 & 0.98 & 0.66 \\
Circle area of uterine cavity & 0.53 & 0.38 & 0.67 & -0.08 \\
Uterine cavity area & 0.56 & 0.43 & 0.70 & -0.25 \\
Uterine cavity circumference & 0.58 & 0.44 & 0.72 & 0.05 \\
Uterine cavity length & 0.57 & 0.41 & 0.72 & -0.14 \\
Uterine cavity width & 0.65 & 0.53 & 0.78 & 0.08 \\
Fundal indentation angle & 0.60 & 0.47 & 0.73 & 0.09 \\
Right lateral internal indentation angle & 0.89 & 0.81 & 0.97 & -0.64 \\
Left lateral internal indentation angle & 0.85 & 0.75 & 0.95 & -0.55 \\
Lateral internal indentation angle average & 0.95 & 0.90 & 0.99 & -0.73 \\
Right cornual angle & 0.60 & 0.45 & 0.76 & -0.05 \\
Left cornual angle & 0.53 & 0.38 & 0.69 & -0.14 \\
Cornual angle average & 0.58 & 0.42 & 0.73 & -0.09 \\
Right T-angle & 0.85 & 0.76 & 0.94 & -0.65 \\
Left T-angle & 0.83 & 0.73 & 0.92 & -0.49 \\
T-angle average & 0.87 & 0.78 & 0.95 & -0.62 \\
Uterine cavity area/uterine cavity circle area & 0.63 & 0.49 & 0.77 & -0.30 \\
Uterine cavity area/uterine cavity circumference & 0.64 & 0.52 & 0.77 & -0.41 \\
Uterine cavity area/uterine cavity circumference ${ }^{2}$ & 0.71 & 0.59 & 0.83 & -0.50 \\
\hline & & & &
\end{tabular}

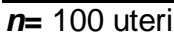


Table S5 - Best cut-off values of selected measurements to define T-shaped uterus, and their agreement with expert opinion (reference standard)

\begin{tabular}{lccccccccccccc}
\hline & Cut-off & Sens & $\mathbf{9 5 \% C l}$ & Spec & $\mathbf{9 5 \% C l}$ & $\mathbf{J}$ & OA & TP & TN & FP & FN & kappa & 95\%Cl \\
\hline LI angle & $<131.6$ & 80 & $56.3-94.3$ & 96.3 & $89.4-99.2$ & 0.76 & $93 \%$ & 16 & 77 & 3 & 4 & 0.78 & $0.69-0.85$ \\
LI depth & $>6.8 \mathrm{~mm}$ & 95 & $75.1-99.9$ & 77.5 & $66.8-86.1$ & 0.73 & $81 \%$ & 19 & 62 & 18 & 1 & 0.55 & $0.40-0.67$ \\
T-angle & $\leq 42$ & 80 & $56.3-94.3$ & 87.5 & $78.2-93.8$ & 0.68 & $86 \%$ & 16 & 70 & 10 & 4 & 0.61 & $0.47-0.72$ \\
\hline
\end{tabular}

$\mathbf{N}=100$ uteri; Ll= lateral internal indentation; J= Youden index; OA= observed agreement; Sens= sensitivity; Spec= specificity; $\mathbf{F P}=$ false positive; $\mathbf{F N}=$ false negative; $\mathbf{T P}=$ true positive; $\mathbf{T N}=$ true negative; $\mathbf{C l}=$ Confidence interval. 
Artigo 2: Definitions, prevalence, clinical implications and treatment of T-shaped uterus: systematic review 


\section{ULTRASOUND in Obstetrics \& Gynecology isuog.}

\section{Definitions, prevalence, clinical implications and treatment of T-shaped uterus: systematic review}

\begin{tabular}{|r|l|}
\hline Journal: & Ultrasound in Obstetrics and Gynecology \\
\hline Manuscript ID & Draft \\
\hline Wiley - Manuscript type: & Systematic Review or Meta-Analysis \\
\hline Author: & n/a \\
\hline Complete List of Authors: & $\begin{array}{l}\text { Coelho Neto, Marcela; University of Sao Paulo, Department of Obstetrics } \\
\text { and Gynecology, Medical School of Ribeirao Preto } \\
\text { Ludwin, Artur; Jagiellonian University,Medical College, Department of } \\
\text { Gynaecology and Oncology } \\
\text { Petraglia, Felice; University of Florence, Department of Biomedical, } \\
\text { Experimental and Clinical Sciences "Mario Serio" } \\
\text { Martins, Wellington; University of Sao Paulo, Department of Obstetrics } \\
\text { and Gynecology, Ribeirao Preto Medical School; }\end{array}$ \\
\hline Keywords: & $\begin{array}{l}\text { Mullerian ducts, Congenital Uterine Anomalies, T-shaped uterus, } \\
\text { Dysmorphic uterus Agreement, lateral indentation, Diethylstilbestrol }\end{array}$ \\
\hline Manuscript Categories: & Gynecology \\
\hline &
\end{tabular}


Title: Definitions, prevalence, clinical implications and treatment of T-shaped uterus: systematic review

Running Title: T-shaped uterus

Authors: M.A. Coelho Neto ${ }^{1,2}$, A. Ludwin ${ }^{3,4}$, F. Petraglia ${ }^{5}$, W.P. Martins ${ }^{6}$

Affiliations: 1) Department of Obstetrics and Gynaecology, Faculty of Medicine of Ribeirão Preto, University of Sao Paulo (DGO-FRMP-USP), Ribeirao Preto, Brazil. 2) Faculty of Medicine of Juazeiro do Norte, Juazeiro do Norte, Brazil. 3) Department of Gynecology and Oncology, Jagiellonian University, Krakow, Poland; 4) Ludwin \& Ludwin Gynecology, Private Medical Center, Krakow, Poland; 5) Department of Clinical and Experimental Biomedical Sciences, University of Florence, Florence, Italy. 5) SEMEAR Fertilidade, Reproductive Medicine, Ribeirao Preto, Brazil.

Study funding/competing interest (s): The authors have no competing interests to declare. 


\section{Abstract}

Objective: This study aims to summarize the current evidence regarding definitions, diagnosis, prevalence, clinical implications and impact of surgical treatment for T-shaped uterus not related to Diethystilbestrol (DES) exposure in a systematic review and to highlight what needs to be better clarified regarding T-shaped uterus.

Methods: A search on PubMed, Scopus and EMBASE was performed on Mar-2020. The following search terms were used: t-shaped OR t-shape OR infantile OR (lateral indentation) OR (Diethylstilbestrol OR DES) AND (uterus OR uterine OR uteri), AND (anomaly OR anomalies OR malformation OR malformations). Additionally, we hand-searched reference list from included studies for other relevant publications. All studies presenting any data regarding T-shaped uterus not related to DES exposure including at least 10 women were considered eligible. All the studies regarding DESrelated T-shaped uterus were excluded because DES is not used since 1971.

Results: The search has found 2,504 records and 20 studies were included in the systematic review. There are only poor-quality studies (observational and quasi-experimental with before-after design). In most of the studies, the diagnosis of T-shaped uterus was based in three-dimensional US (3D-US) (11/16 studies). There is no consensus on definition of T-shaped uterus, but the most cited criteria (4/16 studies) is the criteria from European Society of Human Reproduction and Embryology and the European Society for Gynecological Endoscopy (ESHRE/ESGE) 2013 (narrow uterine cavity 
due to thickened lateral walls with a correlation $2 / 3$ uterine corpus and $1 / 3$ cervix), which is subjective.

The prevalence of T-shaped uterus varied from $0.2-10 \%$ in the included studies. Regarding etiology of T-shaped uterus except for DES, there was mention to adenomyosis ( 1 study); adhesions (5 studies) and it was cited as primary condition (3 studies). Worse reproductive outcomes were related to T-shaped uterus due to infertility (9 studies), miscarriage (7 studies), preterm delivery (2 studies), ectopic pregnancy ( 1 study) and repeated implantation failure (7 studies). From the studies that analyzed benefits of surgical treatment by hysteroscopic metroplasty (12 studies), some of them had mentioned some improvement on pregnancy rate (8 studies), live birth rate (7 studies), term delivery rate (4 studies), reduction in miscarriage ( 5 studies) and ectopic pregnancy ( 1 study), but the evidence is of very low quality.

Conclusions: Until now, prevalence, clinical relevance, and impact of surgery on reproductive outcomes in women with T-shaped uterus is unknown. There is no clear definition and widely accepted measurable criteria for distinguishing between T-shaped and normal uterus. Some studies correlate T-shaped uterus etiologically with adhesions and adenomyosis. Some studies report improvement on reproductive outcomes after surgery, but the evidence is of very low quality. There are no studies with control group, and it is quite probable that women with normal uterus are being submitted to metroplasty due to still questionable diagnosis of T-shaped uterus. 
Key words: Mullerian ducts, Congenital Uterine Anomalies, T-shaped uterus, Dysmorphic uterus Agreement, lateral indentation, Diethylstilbestrol 


\section{INTRODUCTION}

T-shaped uterus is considered a congenital uterine malformation consequent to the failure on later development of the uterus (hypoplastic uterus, T-shaped and diethylbestrol (DES) exposure) ${ }^{1}$. Until de 1980s, T-shaped uterus was commonly related to DES exposure in utero, however women are still presenting T-shaped uterus and its causes remains poorly known ${ }^{2}$. T-shaped uterus typically exhibits lateral indentations with narrowed uterine cavity ${ }^{3}$, in which the shape of the endometrial cavity resemble a "T" 2 instead of a triangle.

T-shaped uterus was firstly mentioned by Kauffman in $1977^{4}$ and by Buttran and Gibbons in 1979 ${ }^{5}$ and later in the classification of the American Fertility Society (AFS) in 1988, as being a type VII or DES-related defect ${ }^{6}$. In 2013, the European Society of Human Reproduction and Embryology and the European Society for Gynecological Endoscopy (ESHRE-ESGE) ${ }^{3}$ proposed a definition for Tshaped uterus as presenting a narrow uterine cavity due to thickened lateral walls with a correlation $2 / 3$ uterine corpus and $1 / 3$ cervix $^{3}$.

Because of concerns that T-shaped uterus might be associated with poor reproductive outcomes, hysteroscopic metroplasty has been considered for women with T-shaped uterus. However, there is no robust evidence regarding its effectiveness or safety ${ }^{2}$.

This study aims to summarize the current evidence regarding T-shaped uterus not related to DES exposure and compile all the information regarding definitions (criteria), diagnosis (diagnostic tools, 
accuracy, reliability/agreement), prevalence, clinical implications and effectiveness of interventions for T-shaped uterus in a systematic review and highlight what needs to be better clarified regarding T-shaped uterus.

\section{METHODS}

\section{Protocol registration}

The protocol of this systematic review has been registered on the International prospective register of systematic reviews (PROSPERO, http://www.crd.york.ac.uk/prospero/). The registration number is CRD42019115131.

\section{Eligibility criteria}

All the studies regarding T-shaped uterus not related to DES exposure were included in this systematic review, irrespectively of its design including case series with at least 10 women. We have included studies regardless of their objectives, once we aim to study criteria for definition, diagnostic methods, prevalence, reproductive outcomes and effectiveness of the interventions. We have decided to exclude the studies on DES-related T-shaped uterus because this drug is not used since 1971; if we include those studies, we would actually have a different population than that we are interested, as women currently at reproductive age were not exposed to DES. However, we preferred to include 
the term Diethylstilbestrol OR DES in our search, because of the possibility of some authors might continue using the term DES related anomaly to refer to T-shaped uterus.

\section{Search and selection of the studies}

We searched PubMed, Scopus and EMBASE using the following search terms: t-shaped OR tshape OR infantile OR (lateral indentation) OR (Diethylstilbestrol OR DES) AND (uterus OR uterine OR uteri) AND (anomaly OR anomalies OR malformation OR malformations).

The last search was performed in Apr-09-2020. Titles and abstracts were reviewed independently by two authors (WPM and MACN), checking for duplicates and using the pre-established criteria for inclusion (T-shaped uterus not related to DES-exposure). There were no limitations on language, date of publication or status of publication. We hand-searched the reference list of the included studies and related reviews. Some references were manually added according to their relevance if they have not already been identified in the earlier searches.

Three authors (MACN, WPM and $A L$ ) retrieved the full-text manuscripts of the references considered to be potentially eligible after screening the abstract. This step was especially difficult once there were very old publications, mainly regarding DES exposure and in other languages but English. One author $(A L)$ also asked help for the librarians of his institution to help on finding the full manuscripts.

\section{Data collection/extraction}


Data extraction was performed in a standardized way by two authors (WPM and MACN).

Disagreements were solved by consulting a third author (AL). Eligibility was assessed against the inclusion/exclusion criteria, and selected or rejected, as appropriate. The studies were characterized according to its design.

The following data were extracted from the eligible studies: diagnostic criteria and methods of diagnosis mentioned for T-shaped uterus, prevalence, etiology, clinical relevance of the t-shaped uterus on the reproductive outcomes: subfertility, previous miscarriage, recurrent miscarriage, miscarriage per pregnancy, preterm birth, repeated implantation failure, ectopic pregnancy. For the studies that proposed surgical intervention for treating T-shaped uterus, the type of intervention and description of the intervention was extracted together with the reported reproductive outcomes. The primary outcomes were live birth, clinical pregnancy, miscarriage. We have tried to contact the authors of the original studies to obtain additional data whenever necessary.

\section{Assessment of the quality of the studies}

For the retrospective observational studies, the Newcastle-Ottawa Quality Assessment Form analyzed the assessment of the risk of bias for Cohort Studies (http://www.ohri.ca/programs/clinical_epidemiology/oxford.asp). Reliability/agreement studies were judged according to the Quality Appraisal of Diagnostic Reliability (QAREL) ${ }^{7}$. Diagnostic accuracy studies were judged according to QUADAS-2 8 (https://www.bristol.ac.uk/populationhealth 
sciences/projects/quadas/quadas-2/). Two researchers (MACN and WPM) have independently assessed the risk of bias, and disagreements were solved by consulting a third author (AL).

\section{Overall quality of the body evidence}

The quality of the body of evidence was classified as suggested by GRADE working group (gradeworkinggrooup.org/). We assessed the quality of the evidence according to GRADE criteria (risk of bias, consistency of the effect, imprecision, indirectness and publication bias). The quality of the evidence was evaluated according to GRADE criteria independently by two reviewers. Disagreements were solved by discussion.

The quality of the evidence was interpreted as following 9: High quality: We are very confident that the true effect lies close to that observed on this review. Moderate quality: We are moderate confident in the effect estimate. The true effect is likely to be close to the observed on this review, but there is a possibility that it is substantially different. Low quality: Our confidence in the effect estimate is limited. The true effect may be substantially different from the observed on this review. Very low quality: We have very little confidence in the effect estimate. The true effect is likely to be substantially different from the observed on this review.

\section{Synthesis of the results}

Data was presented in descriptive tables according to the diagnostic criteria, prevalence, clinical relevance and impact of the surgery. As there were no studies considered to be sufficiently similar, 
the results of the individual studies couldn't be combined for meta-analysis and they were synthesized in tables.

\section{RESULTS}

\section{Study selection and characteristics}

The last electronic search was performed on Apr.09.2020, resulting in total of 2,504 records: PubMed ( $n=505)$; Scopus $(n=750)$ and Embase $(n=1,249)$. By manual search, we have included 31 additional studies. Of the 2,535 records, 729 were duplicates, remaining 1,806 references. By reading the title/abstract, we could exclude 1,674 references (studies were not regarding T-shaped uterus).

We have evaluated 132 records as potentially eligible; 112 were excluded because:

- T-shaped uterus related to DES $=64$ records ${ }^{10-73}$

- Not related to T-shaped uterus $=26$ records ${ }^{74-99}$

- Less than 10 women with T-shaped uterus $=15$ records ${ }^{100-114}$

- No detailed results for T-shaped uterus $=4$ records ${ }^{115-118}$.

- Descriptive reviews $=3$ records ${ }^{119-121}$.

We have included 20 studies in this systematic review ${ }^{2,122-140}$ (Figure 1).

\section{Diagnosis of T-shaped uterus}


Sixteen studies have mentioned the diagnosis of T-shaped uterus. The most cited diagnostic method was three-dimensional ultrasound (3D-US) (11 studies). Others mentioned were magnetic resonance imaging (MRI), hysteroscopy, hysterosalpingography (HSG) and two-dimensional ultrasound (2D-US). Considering that 3D-US and MRI are adequate methods for diagnosing uterine malformations because they allow the visualization of the coronal view of the uterus, eleven studies mentioned at least one adequate method for diagnosing T-shaped uterus (Table 1).

From the sixteen studies have mentioned the diagnosis of T-shaped uterus, four studies performed diagnosis of T-shaped uterus in a subjective way ${ }^{126,129,130,138}$. Four studies have used the criteria proposed by ESHRE-ESGE ${ }^{3}$, in which T-shaped uterus presents a narrow uterine cavity due to thickened lateral walls with a correlation $2 / 3$ uterine corpus and $1 / 3$ uterine cervix ${ }^{122,141-143}$, without specifying definition and cut-off for thickened lateral walls and narrow uterine cavity. Eight studies proposed their own criteria for diagnosing T-shaped uterus $2,123,124,127,135,139,144,145$ (Table 1). Before proposing their own diagnostic criteria, Neal et al. $2019^{123}$ and Ludwin et al. $2019^{124}$ have included a step of subjective diagnosis by experts.

One study compared the accuracy of multi-expert subjective opinion to measurements performed by 3D-US ${ }^{124}$. The definition proposed for T-shaped uterus by the CUME group ${ }^{124}$ with strict measurable criteria based on diagnosis made most often by independent experts: lateral indentation angle $>130^{\circ}$, lateral indentation depth $>7 \mathrm{~mm}$ and T-angle $\leq 40^{\circ}$ with good diagnostic accuracy and 
moderate inter-observer reproducibility. The classification was published recently ${ }^{124}$ and it was still not used by other authors.

\section{Prevalence}

The studies have started from different populations, women undergoing hysteroscopy due to infertility ${ }^{135}$, infertile women undergoing in vitro fertilization (IVF) ${ }^{123}$, patients with singleton pregnancies with uterine anomaly diagnosed during pregnancy ${ }^{136}$, and women with adenomyosis ${ }^{133}$. Considering these different populations mentioned, the prevalence of T-shaped uterus varied from $0.2-10 \%$ in the different studies (Table 2). None of the studies that provided data to infer prevalence have mentioned the diagnostic criteria used to identify T-shaped uterus ${ }^{133,136}$ nor provided objective measurements for the diagnosis of T-shaped uterus ${ }^{135}$.

\section{Etiology}

Some authors mentioned that the etiology of T-shaped uterus is unknown ${ }^{142}$, but it may also be primary ${ }^{135}$ or secondary to adhesions $2,126,135,142$. One study has related T-shaped uterus to adenomyosis ${ }^{133}$ (Table 3). These studies have mentioned the causes above, but there is no research focusing on studying etiology.

\section{Reproductive outcomes}

T-shaped uterus is generally reported as related to worse reproductive outcomes. Nine studies have highlighted the association between subfertility and T-shaped uterus $122,123,126,127,129,130,138,141$, 
142. Some studies have included only patients with subfertility 122, 123, 126, 129, 130, 138. Moreover, two studies have included women with unexplained subfertility ${ }^{127,129}$, while three others have included women with other cause of subfertility 122, 126, 142 . Two studies provided a group of control for comparison (subfertile patients with normal uterus) 122,123 . The prevalence of subfertility in T-shaped uterus varied between $45-74.1 \% 127,141,142$, which was considered to be higher than the $15 \%$ found in general population ${ }^{146}$.

Seven studies have included patients with a history of previous miscarriage and T-shaped uterus $122,123,126,127,139,141,147$, with the prevalence varying between $26-50 \%$. Two studies have a group of control (patients with normal uterus) for comparison ${ }^{122,123}$ and it has been shown that the history of previous miscarriage was more common in patients with T-shaped uterus when compared to patients with normal uterus (one study showed a five-fold increase ${ }^{123}$ ). One study has included all patients with the previous history of miscarriage ${ }^{139}$.

Five studies have mentioned on recurrent miscarriage and T-shaped uterus 122, 123, 126, 127, 141. Two studies has compared T-shaped with normal uterus, showing a higher prevalence of recurrent miscarriage in patients with T-shaped uterus: $20 \%$ vs. $10.2 \%{ }^{123}$ and $17.6 \%$ vs. $10.8 \% 122$. For the other studies it is possible to infer the higher prevalence of recurrent miscarriage in patients with $\mathrm{T}$ shaped uterus: $18-33 \% 126,127,135,141$ vs. approximately $5 \%$ in the general population ${ }^{148}$. One study doesn't mention what they meant by repeated pregnancy loss ${ }^{123}$. The most definition used was two 
or more spontaneous early pregnancy loss ${ }^{122,126,127}$ and two studies added a negative workup including karyotype analysis and antiphospholipid syndrome ${ }^{126,127 .}$ Two studies reported a very high rate of miscarriage per clinical pregnancy: $>80 \%^{129,142}$ and two studies reported a high rate of preterm delivery related to T-shaped uterus: $20-85 \%{ }^{129,} 136$.

Seven studies reported prevalence of repeated implantation failure in patients presenting T-shaped uterus, which varied between $25-28 \%$ 122, 123, 126, 127, 129, 130, 147 . The definition of repeated implantation failure was not uniform by the studies. Two studies have mentioned 2 or more failed IVF despite good quality embryos ${ }^{126,127}$ found RIF in approximately $25 \%$ of the women; one study defined as the absence of pregnancy after $\geq 5$ embryos transferred ${ }^{130}$ and has included the totality of patients presenting RIF; one study defined it as $\geq 3$ failed IVF cycles ${ }^{122}$; one study described the number of failures by patient ${ }^{129}$. One study didn't provide a definition for repeated implantation failure ${ }^{123}$ but provided a group of control for comparison with prevalence of $10 \%$ in women with T-shaped uterus vs. $7 \%$ in women with normal uterus. The most accepted definition for repeated implantation failure in literature consists in three consecutive IVF attempts, in which one to two embryos of high-grade quality are transferred and that the expected prevalence of RIF is approximately $10 \%{ }^{149}$. Considering such $10 \%$ expected prevalence of three consecutive negative pregnancy tests following embryo transfer (the studies on T-shaped uterus didn't mention the quality of the embryos transferred, and therefore the expected prevalence would be higher), we found that one study showed a much higher 
proportion of RIF in women with T-shaped uterus $(35 \%){ }^{122}$, one study reported an expected proportion of RIF in women with T-shaped uterus (14\%) ${ }^{126}$, and one study reported a lower proportion of RIF in women with T-shaped uterus (3.6\%) ${ }^{129}$.

One study depicted a $15 \%$ prevalence of ectopic pregnancies in women with T-shaped uterus ${ }^{129}$ , much higher than the $1-2 \%$ expected in the general population ${ }^{150}$.

\section{Impact of surgery}

Since there are some concerns that T-shaped uterus might be associated with poor reproductive outcomes, some authors are proposing hysteroscopic metroplasty as potential "treatment" for Tshaped uterus. Recently, a cascade of surgical reports on metroplasty of T-shaped uterus has been produced $2,122,126,127,129,132,138,139,141,142,144,147$ (Table 5).

All the studies have mentioned improvement on reproductive outcomes after metroplasty for patients with T-shaped: 8 studies reported improvement on pregnancy rate $122,126,127,129,138,141,142,147$, 6 studies reported improvement on live birth rate $2,122,127,132,138,141,144,5$ studies reported reduction in miscarriage rate $2,127,129,142,144,4$ studies reported improvement on term delivery rate $129,138,139,142$, and 1 study reported reduction on ectopic pregnancy ${ }^{129}$ (Table 6).

One study didn't ask for approval of the Institutional review board ${ }^{141}$. The surgical technique used for T-shaped uterus had a great variation across the identified studies; moreover, we didn't find any randomized controlled trial $(\mathrm{RCT})$, only observational studies, and none of them had a control group 
of untreated women for comparison. Four studies recognized the controversy of indicating metroplasty for women with T-shaped uterus $126,130,141,144$. Nine studies recognized the need of prospective controlled trials to delineate a recommendation for hysteroscopic metroplasty for patients with T-shaped uterus 2, 122, 126, 127, 129, 130, 135, 139, 141.

\section{Eligible studies that didn't provide data for analysis}

We couldn't evaluate reproductive outcomes of five studies because it was not possible to extract data for analysis. Fernandez et al. $2011^{2}$ and Sukur et al. $2018^{142}$ have included patients who were not exposed to DES and also patients exposed to DES, and the outcomes were not reported separately. For two studies, we could only extract data regarding miscarriage per pregnancy ${ }^{142}$ and previous miscarriage ${ }^{139}$ because they have reported the outcomes per pregnancy and not per participant. Two studies haven't report reproductive outcomes of the patients before metroplasty ${ }^{132}$, 138.

Di Spiezio Sardo et al. $2015^{135}$, Ferro et al. $2018^{130}$ and De Bruyn 2013 et al. ${ }^{143}$ included patients with other uterine malformations and the outcomes after surgical treatment were not reported

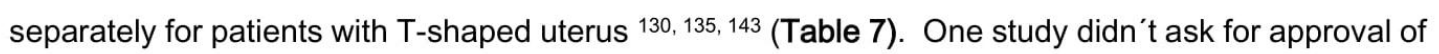
the Institutional review board ${ }^{135}$.

\section{Quality of the studies}


Among the retrospective observational studies (Supplemental Table 1), most of them were considered as being of poor quality, except one that was rated as moderate ${ }^{136}$ (it was useful for the study of prevalence and clinical relevance of T-shaped uterus). The only identified diagnostic accuracy study was judged as having low risk of bias ${ }^{8}$ (Supplemental Table 2). The same study was the only one assessing the reliability/agreement, being considered of moderate quality 110,115 (Supplemental Table 3). All the studies assessing interventions were of poor quality (observational and quasi-experimental with before-after design).

\section{Quality of the evidence}

The quality of the evidence was very low: the quality of the evidence was downgraded two levels because only observational studies were included. Further downgrade should be performed because of important limitations of the included studies, including not having control group and high risk of bias. Moreover, the quality of the evidence should also be downgraded because of serious imprecision (studies with small sample size, median $=47 ; \mathrm{p} 25-75=19.5-80.5$ ) and inconsistency on the results observed across studies.

\section{DISCUSSION}

The included studies in this systematic review have used different criteria for diagnosing T-shaped uterus and have used selected population (women with impaired reproductive outcomes). The prevalence of T-shaped uterus varied between $0.2-10 \%$. The related causes of T-shaped uterus were 
Ultrasound in Obstetrics and Gynecology

adhesions, adenomyosis and primary origin. The diagnosis was performed by different methods, and the most cited was 3D-US. There was no universally accepted definition for T-shaped uterus, although the most cited definition was the one from ESHRE-ESGE ${ }^{3}$. T-shaped uterus was related to worse reproductive outcomes (subfertility, miscarriage, preterm delivery, repeated implantation failure and ectopic pregnancy). Surgical treatment for T-shaped uterus has been proposed, and the available studies have reported a very optimistic improvement on reproductive outcomes after surgery as improvement on pregnancy rates, live birth rates, term delivery and reduction on miscarriage and ectopic pregnancy. This systematic review revealed that that available evidence for all the aspects of T-shaped uterus, particularly regarding the interventions is of very low quality.

Besides using an adequate diagnostic method for identifying T-shaped uterus, the criteria used for defining T-shaped uterus has big importance to assure that T-shaped uteri are identified correctly, and to avoid classification of normal uteri as being T-shaped. The ESHRE/ESGE definition for Tshaped uterus ${ }^{3}$, the most used by the studies may be unclear and misinterpreted by users, once the diagnosis is subjective and made by the impression of the observer. It is not clear what is 'narrow' and 'thickened' by measurable cut-offs. There is no mention to how the measurements of the uterus should be performed, what raise the doubt of the real occurrence of T-shaped uterus.

The reports regarding surgery was very uncommon before ESHRE-ESGE classification of congenital uterine anomalies, which has been pointed as potential iatrogenic etiologic factor, working 
as a trampoline for promoting identification of a 'congenital anomaly' for normal uterus or benign conditions ${ }^{151,152}$ and increasing the rates of prevalence and surgical treatment of patients with normal uterus ${ }^{153,154}$. The widening of the diagnostic boundaries of T-shaped uterus (before it was only DESrelated anomaly) and active promoting its public awareness as disease with very poor prognosis may be an example of disease mongering for extend the use of hysteroscopy. For women presenting subfertility, current concerns are associated with selling unproved fertility treatment, which has been considered as unethical ${ }^{155}$.

The definition proposed for T-shaped uterus by the CUME group ${ }^{124}$ has a potential to facilitate the study of the prevalence, clinical relevance of T-shaped uterus and make possible to study the reproductive outcomes after surgical treatment. Despite being based in expert opinion, the CUME group developed a methodology to determine objective and measurable criteria, and there were not experts with known financial conflict of interests related to hysteroscopic equipment industries. Before CUME there was no measurable criteria for T-shaped uterus (Figure $2,3,4$ ).

None of the studies have included a group of untreated patients with expectant management to help on the study of natural history of disease and to evaluate the efficacy of the surgical intervention on reproductive outcomes. The lack of studies without any treatment indicates the high publication bias. The prevalence and impact of T-shaped uterus on reproductive outcome is still completely unknown, because the patients identified with T-shaped uterus have previous history of impaired 
reproductive outcomes (patients from general population are not searched into uterine anomalies once they are asymptomatic).

Clinical implications of T-shaped uterus were assessed in the context of observational studies and poorly defined diagnostic criteria. In this review, the authors are not able to recognize the benefit of surgical treatment for T-shaped uterus despite of the very optimistic reported outcomes. Randomized trials including a group of untreated patients for comparison would be required to better study the efficacy of the surgical intervention on reproductive outcomes $2,122,126,127,129,130,135,139,141$. Despite of being a non-frequent condition, some authors found a number of patients with T-shaped uterus in a period of up to two years $123,124,126,127,135,147$, what raises the question whether this condition is being overdiagnosed.

This systematic review has as an important limitation the inclusion of observational studies to evaluate reproductive outcomes after surgical treatment with the absence of a control group. The included studies didn't use the same diagnostic criteria for defining T-shaped uterus, and the surgical technique proposed for treating the condition varied along the studies. Also, the authors of this systematic review have published the most recent definition of T-shaped uterus ${ }^{124}$. To deal with the risk of bias related to the assessment of the quality of the studies, a neutral person was invited to review the data extracted and the judgement of the study and to review what was provided by the authors. 
A review was published while we were already working on our review focused on reproductive outcomes following hysteroscopic metroplasty of patients with T-shaped uterus and previous history of poor reproductive outcomes ${ }^{156}$. The authors have included 15 articles in the review (8 published articles and 7 conference abstracts), from which we have also included $72,132,135,138,139,143,144$. We have considered ineligible 7 studies (two studies have included patients exposed to DES 157, 158, other two have included less 10 women with T-shaped uterus ${ }^{113,159}$ and two because the authors have included patients with dysmorphic uterus, and haven't reported the outcomes separately for T-shaped uterus ${ }^{160,} 161$ and one study because there was no mention to T-shaped uterus $\left.{ }^{162}\right)$. The remnant study was not included in the list of references of the review, so we couldn't identify it. The authors have concluded that hysteroscopic metroplasty is a simple procedure which can potentially improve reproductive outcomes, but the data is not robust.

For the future studies, there is a need for reliable and widely accepted criteria for diagnosing Tshaped uterus. Maybe the definition proposed by CUME will help on this. Studies evaluating whether T-shaped uterus is associated with worse reproductive outcomes will be needed (there are only published data regarding patients with T-shaped uterus and impaired reproductive outcomes, we do not know its relevance in general population). If there is an association to impaired reproductive outcomes, an RCT evaluating the effectiveness of metroplasty in improving the reproductive outcomes will be necessary before performing surgery in clinical practice. The challenges regarding 
T-shaped uterus are the same of septate uterus: hysteroscopic septum resection for septate uterus is being performed worldwide for more than 30 years without supporting evidence ${ }^{163,164}$. Such approach causes unnecessary risks and imposes considerable financial burden on healthcare systems ${ }^{165-167}$. Another important issue of performing hysteroscopic metroplasty before we have good evidence about its effectiveness and safety is difficulties for recruiting participants on clinical trials when there is an overall agreement that the interventions is effective. The only concluded (but still unpublished) RCT on the topic needed more than 10 years to randomize 68 women ${ }^{168}$; we hope their results will soon be available, providing some light to this important topic.

\section{$\underline{\text { Conclusions }}$}

The true prevalence, clinical relevance, causes and associations of T-shaped uterus is still not known, as the available studies didn't use clear definition/criteria for the diagnosis of this condition. Additionally, little is known regarding the effect of the proposed intervention for T-shaped uterus, as hysteroscopic metroplasty; in addition to the problems regarding the proper diagnosis, there is no RCT and the available observational studies didn't even have a control group for comparison. 


\section{References}

1. Acien $\mathrm{P}$, Acien $\mathrm{M}$. The presentation and management of complex female genital malformations. Hum Reprod Update 2016; 22: 48-69.

2. Fernandez H, Garbin O, Castaigne V, Gervaise A, Levaillant JM. Surgical approach to and reproductive outcome after surgical correction of a T-shaped uterus. Hum Reprod 2011; 26: 1730-1734.

3. Grimbizis GF, Gordts S, Di Spiezio Sardo A, Brucker S, De Angelis C, Gergolet M, Li TC, Tanos V, Brolmann H, Gianaroli L, Campo R. The ESHRE/ESGE consensus on the classification of female genital tract congenital anomalies. Hum Reprod 2013; 28: 2032-2044.

4. Kaufman RH, Binder GL, Gray PM, Adam E. Upper genital tract changes associated with exposure in utero to diethylstilbestrol. American Journal of Obstetrics and Gynecology 1977; 128: 51-59.

5. Buttram VC, Jr., Gibbons WE. Mullerian anomalies: a proposed classification. (An analysis of 144 cases). Fertil Steril 1979; 32: 40-46.

6. AFS. The American Fertility Society classifications of adnexal adhesions, distal tubal occlusion, tubal occlusion secondary to tubal ligation, tubal pregnancies, mullerian anomalies and intrauterine adhesions. Fertil Steril 1988; 49: 944-955.

7. Lucas NP, Macaskill P, Irwig L, Bogduk N. The development of a quality appraisal tool for studies of diagnostic reliability (QAREL). J Clin Epidemiol 2010; 63: 854-861.

8. Whiting PF, Rutjes AW, Westwood ME, Mallett S, Deeks JJ, Reitsma JB, Leeflang MM, Sterne JA, Bossuyt PM, Group Q-. QUADAS-2: a revised tool for the quality assessment of diagnostic accuracy studies. Ann Intern Med 2011; 155: 529-536.

9. Balshem H, Helfand M, Schunemann HJ, Oxman AD, Kunz R, Brozek J, Vist GE, Falck-Ytter Y, Meerpohl J, Norris S, Guyatt GH. GRADE guidelines: 3. Rating the quality of evidence. J Clin Epidemiol 2011; 64: 401-406.

10. Ahmadi F, Haghighi H. Detection of Congenital Mullerian Anomalies by Real-time 3D Sonography. J Reprod Infertil 2012; 13: 65-66.

11. Mor E, Landay M, Paulson RJ. Endometrial receptivity is preserved in Diethylstilbestrol-associated and other Mullerian anomalies: evidence from tubal embryo transfer. J Assist Reprod Genet 2009; 26: 65-68.

12. Poncelet C, Aissaoui F. [Uterine malformations and reproduction]. Gynecol Obstet Fertil 2007; 35: 821-825.

13. Epelboin S. [Diethylstilbestrol exposure in utero. Polemics about metroplasty. The cons]. Gynecol Obstet Fertil 2007; 35: 832-841.

14. Aubriot FX, Chapron C. [Diethylstilbestrol exposure in utero. Polemics about metroplasty. The pros]. Gynecol Obstet Fertil 2007; 35: 826-831.

15. Garbin O, Ziane A, Castaigne V, Rongieres C. [Do hysteroscopic metroplasties really improve really reproductive outcome?]. Gynecol Obstet Fertil 2006; 34: 813-818.

16. Devi Wold AS, Pham N, Arici A. Anatomic factors in recurrent pregnancy loss. Semin Reprod Med 2006; 24: 25-32.

17. Porcu G, Heckenroth H. Malformations utérines et infertilité. EMC - Gynécologie-Obstétrique 2005; 2: $185-197$.

18. Troiano RN, McCarthy SM. Mullerian duct anomalies: imaging and clinical issues. Radiology 2004; 233: 19-34.

19. Lin PC. Reproductive outcomes in women with uterine anomalies. J Womens Health (Larchmt) 2004; 13: 33-39.

20. Aubriot FX, Audebert A, Blanc B, Dechaud H, Elpelboin S, Fernandez H, Garbin O, Hamou J, Landowski P, Paniel BJ, Tournaire M, Salle B, Mergui JL, Agence nationale d'accreditation et d'evaluation en s. [Evaluation of enlargement uteroplasty in the treatment of uterine anomalies following exposure to diethylstillbestrol (May 2003)]. Gynecol Obstet Fertil 2004; 32: 261-264; discussion 261.

21. Troiano RN. Magnetic resonance imaging of mullerian duct anomalies of the uterus. Top Magn Reson Imaging 2003; 14: 269-279.

22. Siewert B, Hochman M, Levine D. Problems and Pitfalls in MR Evaluation of Uterine Anomalies. Journal of Women's Imaging 2002; 4: 100-107. 
23. Aubriot FX, Hamou J, Dubuisson JB, Frydman R, Fernandez H. [Hysteroplasty for enlargement: apropos of the results]. Gynecol Obstet Fertil 2001; 29: 888-893.

24. Goldberg JM, Falcone T. Effect of diethylstilbestrol on reproductive function. Fertil Steril 1999; 72: 17.

25. Laurent $\mathrm{S}$, Lanoue $\mathrm{M}$, Lecomte $\mathrm{C}$, Bourgeois L, Lecomte $\mathrm{P}$. [Female fertility prognosis and diethylstilbestrol. Personal data and review of the literature]. J Gynecol Obstet Biol Reprod (Paris) 1998; 27: 277-284.

26. Garbin O, Ohl J, Bettahar-Lebugle K, Domine S, Dellenbach P. [Transcervical hysteroplasty: indications, techniques and results. 125 cases]. Contracept Fertil Sex 1997; 25: 843-851.

27. Raga F, Bauset C, Remohi J, Bonilla-Musoles F, Simon C, Pellicer A. Reproductive impact of congenital Mullerian anomalies. Hum Reprod 1997; 12: 2277-2281.

28. Noyes N, Liu HC, Sultan K, Rosenwaks Z. Endometrial pattern in diethylstilboestrol-exposed women undergoing in-vitro fertilization may be the most significant predictor of pregnancy outcome. Hum Reprod 1996; 11: 2719-2723.

29. Lang JM, Lieberman E, Cohen A. A comparison of risk factors for preterm labor and term small-forgestational-age birth. Epidemiology 1996; 7: 369-376.

30. Kipersztok S, Javitt M, Hill MC, Stillman RJ. Comparison of magnetic resonance imaging and transvaginal ultrasonography with hysterosalpingography in the evaluation of women exposed to diethylstilbestrol. J Reprod Med 1996; 41: 347-351.

31. Minh HN, Smadja A, Gasnault JP. [From embryogenesis to pathogenesis of effects of diethylstilbestrol on the female genital tract]. Presse Med 1993; 22: 1052-1057.

32. Milhan D. DES exposure: implications for childbearing. Int J Childbirth Educ 1992; 7: 21-28.

33. Balasch J, Coll O, Jove I, Moreno V, Mulet J, Vanrell JA. Diethylstilbestrol-induced mullerian abnormalities, septate uterus, genital tuberculosis and twin pregnancy with term delivery after in-vitro fertilization. Hum Reprod 1991; 6: 690-693.

34. Sherer DM, Allen TA, Woods Jr JR. Endovaginal sonographic associated features of a T-shaped uterus due to in utero exposure to diethylstilbestrol (DES). Journal of Diagnostic Medical Sonography 1990; 6: 318320.

35. Lev-Toaff AS, Toaff ME, Friedman AC. Endovaginal sonographic appearance of a DES uterus. $J$ Ultrasound Med 1990; 9: 661-664.

36. Karande VC, Lester RG, Muasher SJ, Jones DL, Acosta AA, Jones HW, Jr. Are implantation and pregnancy outcome impaired in diethylstilbestrol-exposed women after in vitro fertilization and embryo transfer? Fertil Steril 1990; 54: 287-291.

37. Claman P, Berger MJ. Phenotypic differences in upper genital tract abnormalities and reproductive history in dizygotic twins exposed to diethylstilbestrol in utero. A case report. J Reprod Med 1990; 35: 431433.

38. van Gils AP, Tham RT, Falke TH, Peters AA. Abnormalities of the uterus and cervix after diethylstilbestrol exposure: correlation of findings on MR and hysterosalpingography. AJR Am J Roentgenol 1989; 153: 1235-1238.

39. Kahn-Nathan J. Diethylstilbestrol exposition in utero. Effects on female genital tract. Contraception Fertilite Sexualite 1989; 17: 243-245.

40. Hammond MG. Mullerian defects associated with repetitive spontaneous abortions. Seminars in Reproductive Endocrinology 1989; 7: 103-110.

41. Senekjian EK, Potkul RK, Frey K, Herbst AL. Infertility among daughters either exposed or not exposed to diethylstilbestrol. Am J Obstet Gynecol 1988; 158: 493-498.

42. Cunha GR, Taguchi O, Namikawa R, Nishizuka Y, Robboy SJ. Teratogenic effects of clomiphene, tamoxifen, and diethylstilbestrol on the developing human female genital tract. Hum Pathol 1987; 18: 11321143.

43. Menczer J, Dulitzky M, Ben-Baruch G, Modan M. Primary infertility in women exposed to diethylstilboestrol in utero. Br J Obstet Gynaecol 1986; 93: 503-507. 
44. Kaufman RH, Adam E, Noller K, Irwin JF, Gray M. Upper genital tract changes and infertility in diethylstilbestrol-exposed women. Am J Obstet Gynecol 1986; 154: 1312-1318.

45. Barber HR. An update on DES in the field of reproduction. Int J Fertil 1986; 31: 130-144.

46. Tchobroutsky C. Reproduction in women exposed in utero to diethylstilbestrol (DES). Semaine des Hopitaux 1984; 60: 1743-1744.

47. Nunley WC, Jr., Pope TL, Jr., Bateman BG. Upper reproductive tract radiographic findings in DESexposed female offspring. AJR Am J Roentgenol 1984; 142: 337-339.

48. Muasher SJ, Acosta AA, Garcia JE, Rosenwaks Z, Jones HW, Jr. Wedge metroplasty for the septate uterus: an update. Fertil Steril 1984; 42: 515-519.

49. Kaufman RH, Noller K, Adam E, Irwin J, Gray M, Jefferies JA, Hilton J. Upper genital tract abnormalities and pregnancy outcome in diethylstilbestrol-exposed progeny. Am J Obstet Gynecol 1984; 148: 973-984.

50. Huikeshoven FJ, Wallenburg HC. [DES, more than an oncological problem]. Ned Tijdschr Geneeskd 1984; 128: 1553-1556.

51. Drapier E. [Fertility disorders attributable to the use of diethylstilbestrol during intrauterine life]. Rev Fr Gynecol Obstet 1984; 79: 297-300, 303-295.

52. Buttram VC. Müllerian anomalies and their management. Fertility and Sterility 1983; 40: 159-163.

53. Belaisch J. [Exposure to diethylstilbestrol during intrauterine life. Signs that should suggest this. Therapeutic implications]. J Gynecol Obstet Biol Reprod (Paris) 1983; 12: 481-488.

54. Stillman RJ. In utero exposure to diethylstilbestrol: adverse effects on the reproductive tract and reproductive performance and male and female offspring. Am J Obstet Gynecol 1982; 142: 905-921.

55. Mansi ML, Goldfarb AF. An analysis of pregnancy salvage in a selective DES population. Infertility 1982; 5: 1-13.

56. Kinch RA. Diethylstilbestrol in pregnancy: an update. Can Med Assoc J 1982; 127: 812-813.

57. Kaufman RH. Structural changes of the genital tract associated with in utero exposure to diethylstilbestrol. Obstet Gynecol Annu 1982; 11: 187-202.

58. Caby J. Uterine anomalies in young women exposed to diethylstilbestrol in utero. Hysterographic findings in three cases. Gynecologie 1982; 33: 515-521.

59. Sandberg EC, Riffle NL, Higdon JV, Getman CE. Pregnancy outcome in women exposed to diethylstilbestrol in utero. Am J Obstet Gynecol 1981; 140: 194-205.

60. Ben-Baruch G, Menczer J, Mashiach S, Serr DM. Uterine anomalies in diethylstilbestrol-exposed women with fertility disorders. Acta Obstet Gynecol Scand 1981; 60: 395-397.

61. Viscomi GN, Gonzalez R, Taylor KJ. Ultrasound detection of uterine abnormalities after diethylstilbestrol (DES) exposure. Radiology 1980; 136: 733-735.

62. Pillsbury SG, Jr. Reproductive significance of changes in the endometrial cavity associated with exposure in utero to diethylstilbestrol. Am J Obstet Gynecol 1980; 137: 178-182.

63. Kaufman RH, Adam E, Binder GL, Gerthoffer E. Upper genital tract changes and pregnancy outcome in offspring exposed in utero to diethylstilbestrol. Am J Obstet Gynecol 1980; 137: 299-308.

64. Goldstein DP. The significance of cervical and uterine abnormalities in DES-exposed females. Journal of Adolescent Health Care 1980; 1: 86.

65. Barnes AB, Colton T, Gundersen J, Noller KL, Tilley BC, Strama T, Townsend DE, Hatab P, O'Brien PC. Fertility and outcome of pregnancy in women exposed in utero to diethylstilbestrol. N Engl J Med 1980; 302: 609-613.

66. Siegler AM, Wang CF, Friberg J. Fertility of the diethylstilbestrol-exposed offspring. Fertil Steril 1979; 31: 601-607.

67. Rennell CL. T-shaped uterus in diethylstilbestrol (DES) exposure. AJR Am J Roentgenol 1979; 132: 979-980.

68. Haney AF, Hammond CB, Soules MR, Creasman WT. Diethylstilbestrol-induced upper genital tract abnormalities. Fertil Steril 1979; 31: 142-146.

69. Kaufman RH, Adam E. Genital tract anomalies associated with in utero exposure to diethylstilbestrol. Isr J Med Sci 1978; 14: 353-362. 
70. Goldstein DP. Incompetent cervix in offspring exposed to diethylstilbestrol in utero. Obstet Gynecol 1978; 52: 73s-75s.

71. Kaufman RH, Binder GL, Gray Jr PM, Adam E. Upper genital tract changes associated with exposure in utero to diethylstilbestrol. Am J Obstet Gynecol 1977; 128: 51-59.

72. Garbin O, Dellenbach P. [Hysteroscopic metroplasty for uterine enlargement: a treatment for diethylbestrol-exposed and hypoplastic uteri]. J Gynecol Obstet Biol Reprod (Paris) 1996; 25: 41-46.

73. Ansbacher R. Uterine anomalies and future pregnancies. Clin Perinatol 1983; 10: 295-304.

74. Bhagavath B, Ellie G, Griffiths KM, Winter T, Alur-Gupta S, Richardson C, Lindheim SR. Uterine Malformations: An Update of Diagnosis, Management, and Outcomes. Obstet Gynecol Surv 2017; 72: 377392.

75. Heusinger K, Oppelt PG. Konnatale Fehlbildungen des weiblichen Genitaltrakts. Der Gynäkologe 2016; 49: 79-86.

76. Saravelos SH, Li TC. Intra- and inter-observer variability of uterine measurements with threedimensional ultrasound and implications for clinical practice. Reprod Biomed Online 2015; 31: 557-564.

77. Olpin JD, Heilbrun M. Imaging of Mullerian duct anomalies. Top Magn Reson Imaging 2010; 21: 225235.

78. Raga F, Bonilla-Musoles F, Blanes J, Bailao LA, Osborne NG. Uterine anomalies with threedimemsional ultrasound (Mullerian duct malformations). Assisted Reproduction Reviews 1996; 6: 126-141.

79. Blanc B. Practical guidelines for paraclinical investigation ranking of unterovaginal malformations. Gynecologie 1990; 41: 236-238.

80. Rudigoz RC, Gaucherand P, Dargent D. The obstetric outlook for malformations of the uterus. Journal de Gynecologie Obstetrique et Biologie de la Reproduction 1989; 18: 185-191.

81. Lecoutour $X$, Bourgeot $P$, Segard $C$. Study of 155 pregnancies involving uterine deformity. Revue Francaise de Gynecologie et d'Obstetrique 1986; 81: 357-362.

82. Leroy B, Bessis R, Nisand I, Jeny R, Jaudel S, Eboue F. [The value of ultrasonography in the diagnosis of uterine malformations]. J Gynecol Obstet Biol Reprod (Paris) 1984; 13: 250-253.

83. Blum M. Obstetric complications due to malformations of the uterus. Revue Francaise de Gynecologie et d'Obstetrique 1984; 79: 461-462.

84. de la Pena Regidor P, de Carballo P. [Approach to repeated pregnancy of women with uterine malformation (author's transl)]. Zentralbl Gynakol 1979; 101: 857-858.

85. Rauthe $\mathrm{G}$, Vahrson $\mathrm{H}$. [Infantile and hypoplastic uterus: a contribution to overcome the confusion of terms (author's transl)]. Geburtshilfe Frauenheilkd 1975; 35: 877-880.

86. Erbsloeh J. Normal shapes, variations and malformations in hysterosalpingography. Radiologe 1975; 15: 2-10.

87. Kopaleischwili BI, Gotziridse OA, Friedman MM, Gogitschaischwili LG, Nikulin PP. [New method for inducing functional hypertrophy of a hypoplastic uterus (clinical-experimental study)]. Zentralb/ Gynakol 1973; 95: 177-181.

88. Empereur-Buisson R. Repeated abortions due to uterine anomaly. Journal des sciences médicales de Lille 1971; 89: 317-321.

89. Wery P. [Essential symptomatology of major types of uterine malformation]. Rev Med Liege 1970; 25: $760-763$.

90. Vaesen F. [Treatment of uterine malformation]. Rev Med Liege 1970; 25: 764-766.

91. Poizat G. [Obstetrical complications of uterine malformations]. Rev Med Liege 1970; 25: 763-764.

92. Musset R, Muller P, Netter A, Solal R. [Necessity for a global classification of uterine malformations. Associated urinary malformations. Interest of certain peculiarities in the light of 141 cases]. Gynecol Obstet (Paris) 1967; 66: 145-166.

93. Chosson J. Attempt at embryologic classification of malformations of Mullerian origin of the female genital system. Revue Francaise de Gynecologie et d'Obstetrique 1967; 62: 695-702.

94. Serment $\mathrm{H}$, Felce A, Hartung N, Tanguy $\mathrm{Y}$. [Apropos of an unusual utero-vaginal malformation]. Bull Fed Soc Gynecol Obstet Lang Fr 1966; 18: 284-285. 
95. Rouchy R. [Repeated abortions \& uterine malformations; Strassmann's operation]. Bull Fed Soc Gynecol Obstet Lang Fr 1957; 9: 229-231.

96. Louros N, Kaskarelis D. Relations between uterine malformation, sterility and abortion. Gynécologie pratique 1957 ; 8: 299-306.

97. Hervet E. [Uterine malformation: new report of a reparative operation]. Bull Fed Soc Gynecol Obstet Lang Fr 1957; 9: 504-510.

98. Ravina J, Musset R, Michel H. [Hypertrophic elongation of the uterine cervix; three observations on congenital hypertrophic elongation]. Bull Fed Soc Gynecol Obstet Lang Fr 1956; 8: 59-63.

99. Caderas De Kerleau J, Thuile F. [Infantile uterus and obstetrical consequences]. Maroc Med 1952; 31: 918-920.

100. Kougioumtsidou A, Mikos T, Grimbizis GF, Karavida A, Theodoridis TD, Sotiriadis A, Tarlatzis BC, Athanasiadis AP. Three-dimensional ultrasound in the diagnosis and the classification of congenital uterine anomalies using the ESHRE/ESGE classification: a diagnostic accuracy study. Arch Gynecol Obstet 2019; 299: 779-789.

101. Alonso Pacheco L, Lagana AS, Ghezzi F, Haimovich S, Azumendi Gomez P, Carugno J. Subtypes of Tshaped uterus. Fertil Steril 2019; 112: 399-400.

102. Thellier E, Levaillant JM, Pourcelot AG, Houllier M, Fernandez H, Capmas P. Are 3D ultrasound and office hysteroscopy useful for the assessment of uterine cavity after late foetal loss? J Gynecol Obstet Hum Reprod 2018; 47: 183-186.

103. Ples L, Alexandrescu C, Ionescu CA, Arvatescu CA, Vladareanu S, Moga MA. Three-dimensional scan of the uterine cavity of infertile women before assisted reproductive technology use. Medicine (Baltimore) 2018; 97: e12764.

104. Ludwin A, Ludwin I. Comparison of the ESHRE-ESGE and ASRM classifications of Mullerian duct anomalies in everyday practice. Hum Reprod 2015; 30: 569-580.

105. Graupera B, Pascual MA, Hereter L, Browne JL, Ubeda B, Rodriguez I, Pedrero C. Accuracy of threedimensional ultrasound compared with magnetic resonance imaging in diagnosis of Mullerian duct anomalies using ESHRE-ESGE consensus on the classification of congenital anomalies of the female genital tract. Ultrasound Obstet Gynecol 2015; 46: 616-622.

106. Imboden S, Muller M, Raio L, Mueller MD, Tutschek B. Clinical significance of 3D ultrasound compared to MRI in uterine malformations. Ultraschall Med 2014; 35: 440-444.

107. Jaslow CR, Kutteh WH. Effect of prior birth and miscarriage frequency on the prevalence of acquired and congenital uterine anomalies in women with recurrent miscarriage: a cross-sectional study. Fertil Steril 2013; 99: 1916-1922 e1911.

108. Fox N, Roman A, Saltzman D, Klauser C, Rebarber A. 517: Twin pregnancy in patients with a uterine malformation. American Journal of Obstetrics and Gynecology 2013; 208: S222.

109. Jayaprakasan K, Chan YY, Sur S, Deb S, Clewes JS, Raine-Fenning NJ. Prevalence of uterine anomalies and their impact on early pregnancy in women conceiving after assisted reproduction treatment. Ultrasound Obstet Gynecol 2011; 37: 727-732.

110. Bermejo C, Martinez Ten P, Cantarero R, Diaz D, Perez Pedregosa J, Barron E, Labrador E, Ruiz Lopez L. Three-dimensional ultrasound in the diagnosis of Mullerian duct anomalies and concordance with magnetic resonance imaging. Ultrasound Obstet Gynecol 2010; 35: 593-601.

111. Agrawal G, Riherd JM, Busse RF, Hinshaw JL, Sadowski EA. Evaluation of uterine anomalies: 3D FRFSE cube versus standard 2D FRFSE. AJR Am J Roentgenol 2009; 193: W558-562.

112. Barranger E, Gervaise A, Doumerc S, Fernandez H. Reproductive performance after hysteroscopic metroplasty in the hypoplastic uterus: a study of 29 cases. BJOG 2002; 109: 1331-1334.

113. Katz Z, Ben-Arie A, Lurie S, Manor M, Insler V. Beneficial effect of hysteroscopic metroplasty on the reproductive outcome in a 'T-shaped' uterus. Gynecol Obstet Invest 1996; 41: 41-43.

114. Golan A, Langer R, Neuman M, Wexler S, Segev E, David MP. Obstetric outcome in women with congenital uterine malformations. J Reprod Med 1992; 37: 233-236. 
115. Bermejo C, Martinez-Ten P, Ruiz-Lopez L, Estevez M, Gil MM. Classification of Uterine Anomalies by 3-Dimensional Ultrasonography Using ESHRE/ESGE Criteria: Interobserver Variability. Reprod Sci 2018; 25: 740-747.

116. Exacoustos C, Valeria R, Cobuzzi I, Zizolfi B, Di Spiezio A, Zupi E. Abstracts of the 32nd Annual Meeting of the European Society of Human Reproduction and Embryology. Human Reproduction 2016; 31: i1-i513.

117. Adriaensen P, Mestdagh G, Dhont N, Ombelet W, De Bruyn C, Rudi C. Abstracts of the 25th Annual Congress of the European Society for Gynaecological Endoscopy (ESGE), 2nd-5th October 2016, Square Brussels - Belgium. Gynecological Surgery 2016; 13: 1-453.

118. Meier R, De Bruin C, Mestdagh G, Dhont N, Ombelet W, Campo R. Abstracts of the 23rd Annual congress of the European Society European Society (ESGE), 24th - 26th September 2014, SQUARE, BRUSSELS. Gynecological Surgery 2014; 11: 1-358.

119. Li Y, Phelps A, Zapala MA, MacKenzie JD, MacKenzie TC, Courtier J. Magnetic resonance imaging of Mullerian duct anomalies in children. Pediatr Radiol 2016; 46: 796-805.

120. Exacoustos C, Cobuzzi I, Romeo V. 2D Ultrasound (2D US) and Sonohysterography (SHG) for the Diagnosis of Female Genital Anomalies. Female Genital Tract Congenital Malformations: Springer-Verlag London Ltd; 2015:63-78.

121. Ahmadi F, Zafarani F, Shahrzad GS. Hysterosalpingographic Appearances of Female Genital Tract Tuberculosis: Part II: Uterus. Int J Fertil Steril 2014; 8: 13-20.

122. Uyar E, Usal D, Selam B, Cincik M, Bagis T. IVF outcomes after hysteroscopic metroplasty in patients with T- shaped uterus. Fertil Res Pract 2019; 5: 15.

123. Neal SA, Morin SJ, Werner MD, Gueye NA, Pirtea P, Scott RT, Jr., Goodman LR. Three-dimensional ultrasound diagnosis of T-shaped uterus is associated with adverse pregnancy outcomes after embryo transfer. Reprod Biomed Online 2019; 39: 777-783.

124. Ludwin A, Coelho Neto MA, Ludwin I, Nastri CO, Costa W, Acien M, Alcazar JL, Benacerraf B, Condous G, DeCherney A, De Wilde RL, Diamond MP, Emanuel MH, Guerriero S, Hurd W, Levine D, Lindheim S, Pellicer A, Petraglia F, Saridogan E, Martins WP. Congenital Uterine Malformation by Experts (CUME): Tshaped uterus. Ultrasound Obstet Gynecol 2019;

125. Di Spiezio Sardo A, Campo R, Zizolfi B, Santangelo F, Meier Furst R, Di Cesare C, Bettocchi S, Vitagliano A, Ombelet W. Long-Term Reproductive Outcomes after Hysteroscopic Treatment of Dysmorphic Uteri in Women with Reproductive Failure: An European Multicenter Study. J Minim Invasive Gynecol 2020; 27: 755-762.

126. Boza A, Akin OD, Oguz SY, Misirlioglu S, Urman B. Surgical correction of T-shaped uteri in women with reproductive failure: Long term anatomical and reproductive outcomes. J Gynecol Obstet Hum Reprod 2019; 48: 39-44.

127. Alonso Pacheco L, Lagana AS, Garzon S, Perez Garrido A, Flores Gornes A, Ghezzi F. Hysteroscopic outpatient metroplasty for T-shaped uterus in women with reproductive failure: Results from a large prospective cohort study. Eur J Obstet Gynecol Reprod Biol 2019; 243: 173-178.

128. Sukur YE, Yakistiran B, Ozmen B, Sonmezer M, Berker B, Atabekoglu C. Hysteroscopic Corrections for Complete Septate and T-Shaped Uteri Have Similar Surgical and Reproductive Outcome. Reprod Sci 2018; 25: 1649-1654.

129. Haydardedeoglu B, Dogan Durdag G, Simsek S, Caglar Aytac P, Cok T, Bulgan Kilicdag E. Reproductive outcomes of office hysteroscopic metroplasty in women with unexplained infertility with dysmorphic uterus. Turk J Obstet Gynecol 2018; 15: 135-140.

130. Ferro J, Labarta E, Sanz C, Montoya P, Remohi J. Reproductive outcomes after hysteroscopic metroplasty for women with dysmorphic uterus and recurrent implantation failure. Facts Views Vis Obgyn 2018; 10: 63-68.

131. Ducellier-Azzola G, Lecointre L, Hummel M, Pontvianne M, Garbin O. Hysteroscopic enlargement metroplasty for T-shaped uterus: 24 years' experience at the Strasbourg Medico-Surgical and Obstetrical Centre (CMCO). Eur J Obstet Gynecol Reprod Biol 2018; 226: 30-34. 
132. Soekoer Y, Seval MM, Ozmen B, Sonmezer M, Berker B, Atabekoglu CS. The reproductive outcome after hysteroscopicmetroplasty in patients with deep uterine septum and t-shaped uterus. Fertil Steril 2016; 106 (Suppl 1): 453.

133. Puente JM, Fabris A, Patel J, Patel A, Cerrillo M, Requena A, Garcia-Velasco JA. Adenomyosis in infertile women: prevalence and the role of $3 \mathrm{D}$ ultrasound as a marker of severity of the disease. Reprod Biol Endocrinol 2016; 14: 60.

134. Exacoustos C, Romeo V, Zizolfi B, Cobuzzi I, Di Spiezio A, Zupi E. Dysmorphic Uterine Congenital Anomalies: A New Lateral Angle and a Cavity Width Ratio on 3D Ultrasound Coronal Section to Define Uterine Morphology. J Minim Invasive Gynecol 2015; 22: S73.

135. Di Spiezio Sardo A, Florio P, Nazzaro G, Spinelli M, Paladini D, Di Carlo C, Nappi C. Hysteroscopic outpatient metroplasty to expand dysmorphic uteri (HOME-DU technique): a pilot study. Reprod Biomed Online 2015; 30: 166-174.

136. Fox NS, Roman AS, Stern EM, Gerber RS, Saltzman DH, Rebarber A. Type of congenital uterine anomaly and adverse pregnancy outcomes. J Matern Fetal Neonatal Med 2014; 27: 949-953.

137. De Bruyn C, Greet M, Willem O, Rudi C. Abstracts of the 22nd Annual Congress of the European Society of Gynaecological Endoscopy (ESGE), 16-19 October 2013, Berlin. Gynecological Surgery 2013; 10: 1151.

138. M. M. T shaped endometrial cavity and infertility. Gynecol Surg 2012; 9 (Suppl 1): S1-37.

139. Giacomucci E, Bellavia E, Sandri F, Farina A, Scagliarini G. Term delivery rate after hysteroscopic metroplasty in patients with recurrent spontaneous abortion and T-shaped, arcuate and septate uterus. Gynecol Obstet Invest 2011; 71: 183-188.

140. Ferro J, Lizán C, Ayllón Y, Garrido N, Remohí J. Reproductive surgery. Human Reproduction 2009; 24 : i231-i235.

141. Di Spiezio Sardo A, Campo R, Zizolfi B, Santangelo F, Meier Furst R, Di Cesare C, Bettocchi S, Vitagliano A, Ombelet W. Long-Term Reproductive Outcomes after Hysteroscopic Treatment of Dysmorphic Uteri in Women with Reproductive Failure: An European Multicenter Study. J Minim Invasive Gynecol 2019;

142. Sukur YE, Yakistiran B, Ozmen B, Sonmezer M, Berker B, Atabekoglu C. Hysteroscopic Corrections for Complete Septate and T-Shaped Uteri Have Similar Surgical and Reproductive Outcome. Reprod Sci 2018; 1933719118756774.

143. De Bruyn C, Greet M, Willem O, Rudi C. The impact of hysteroscopic surgery for dysmorphic uterus on reproductive and obstetric outcomes: Pilot study. Gynecological Surgery 2013; 10: S101-S102.

144. Ducellier-Azzola G, Lecointre L, Hummel M, Pontvianne M, Garbin O. Hysteroscopic enlargement metroplasty for T-shaped uterus: 24 years' experience at the Strasbourg Medico-Surgical and Obstetrical Centre (CMCO). European Journal of Obstetrics Gynecology and Reproductive Biology 2018; 226: 30-34.

145. Exacoustos C, Romeo V, Zizolfi B, Cobuzzi I, Di Spiezio A, Zupi E. Dysmorphic uterine congenital anomalies: A new lateral angle and a cavity width ratio on 3D ultrasound coronal section to define uterine morphology. Journal of Minimally Invasive Gynecology 2015; 22: S73.

146. NICE. Fertility problems: assessment and treatment. Fertility: Assessment and Treatment for People with Fertility Problems. London; 2013.

147. Ferro J, Lizán C, Ayllón Y, Garrido N, Remohí J. Pregnancy results after hysteroscopical correction of "T-shape uterus". Molecular Human Reproduction 2009; 24: i232-i233.

148. ESHRE, Bender Atik R, Christiansen OB, Elson J, Kolte AM, Lewis S, Middeldorp S, Nelen W, Peramo B, Quenby S, Vermeulen N, Goddijn M. ESHRE guideline: recurrent pregnancy loss. Hum Reprod Open 2018; 2018:

149. Somigliana E, Vigano P, Busnelli A, Paffoni A, Vegetti W, Vercellini P. Repeated implantation failure at the crossroad between statistics, clinics and over-diagnosis. Reprod Biomed Online 2018; 36: 32-38.

150. Mol F, van Mello NM, Strandell A, Strandell K, Jurkovic D, Ross J, Barnhart KT, Yalcinkaya TM, Verhoeve HR, Graziosi GCM, Koks CAM, Klinte I, Hogstrom L, Janssen I, Kragt H, Hoek A, Trimbos-Kemper TCM, Broekmans FJM, Willemsen WNP, Ankum WM, Mol BW, van Wely M, van der Veen F, Hajenius PJ, European Surgery in Ectopic Pregnancy study g. Salpingotomy versus salpingectomy in women with tubal 
pregnancy (ESEP study): an open-label, multicentre, randomised controlled trial. Lancet 2014; 383: 14831489.

151. Knez J, Saridogan E, Van Den Bosch T, Mavrelos D, Ambler G, Jurkovic D. ESHRE/ESGE female genital tract anomalies classification system-the potential impact of discarding arcuate uterus on clinical practice. Hum Reprod 2018; 33: 600-606.

152. Ludwin A, Ludwin I, Kudla M, Kottner J. Reliability of the European Society of Human Reproduction and Embryology/European Society for Gynaecological Endoscopy and American Society for Reproductive Medicine classification systems for congenital uterine anomalies detected using three-dimensional ultrasonography. Fertil Steril 2015; 104: 688-697 e688.

153. Ludwin A, Martins WP, Nastri CO, Ludwin I, Coelho Neto MA, Leitao VM, Acien M, Alcazar JL, Benacerraf B, Condous G, De Wilde RL, Emanuel MH, Gibbons W, Guerriero S, Hurd WW, Levine D, Lindheim S, Pellicer A, Petraglia F, Saridogan E. Congenital Uterine Malformation by Experts (CUME): better criteria for distinguishing between normal/arcuate and septate uterus? Ultrasound Obstet Gynecol 2018; 51: 101-109.

154. Prior M, Richardson A, Asif S, Polanski L, Parris-Larkin M, Chandler J, Fogg L, Jassal P, Thornton JG, Raine-Fenning NJ. Outcome of assisted reproduction in women with congenital uterine anomalies: a prospective observational study. Ultrasound Obstet Gynecol 2018; 51: 110-117.

155. Day J. Commentary: Selling unproved fertility treatments to women desperate for a baby may be unethical. BMJ 2016; 355: i6434.

156. Sood A, Akhtar M. T-shaped Uterus in the 21(st) Century (Post DES era) - We Need to Know More! J Hum Reprod Sci 2019; 12: 283-286.

157. Garbin O, Ohl J, Bettahar-Lebugle K, Dellenbach P. Hysteroscopic metroplasty in diethylstilboestrolexposed and hypoplastic uterus: a report on 24 cases. Hum Reprod 1998; 13: 2751-2755.

158. Nagel TC, Malo JW. Hysteroscopic metroplasty in the diethylstilbestrol-exposed uterus and similar nonfusion anomalies: effects on subsequent reproductive performance; a preliminary report. Fertil Steril 1993; 59: 502-506.

159. Barranger E, Gervaise A, Doumerc S, Fernandez H. Reproductive performance after hysteroscopic metroplasty in the hypoplastic uterus: A study of 29 cases. BJOG: An International Journal of Obstetrics and Gynaecology 2002; 109: 1331-1334.

160. Meier R, De Bruin C, Mestdagh G, Dhont N, Ombelet W, Campo R. Reproductive outcomes after hysteroscopic management of dysmorphic uterus: Report of 100 cases. Gynecological Surgery 2014; 11: 154.

161. Adriaensen P, Mestdagh G, Dhont N, Ombelet W, De Bruyn C, Rudi C. Reproductive and obstetric outcomes of hysteroscopic correction of a dysmorphic (U1). Gynecol Surg 2016; 13(Suppl 1): 453.

162. Dzotsenidze TN, Davarashvili DI, Nikolaishvili TG, Peradze DG, Datunashvili ED. [Contrast sono hysterosalpingography in the study of endometrial abnormalities and tubal patency in infertile patients]. Georgian Med News 2006; 61-63.

163. Rikken JF, Kowalik CR, Emanuel MH, Mol BW, Van der Veen F, van Wely M, Goddijn M. Septum resection for women of reproductive age with a septate uterus. Cochrane Database Syst Rev 2017; 1: CD008576.

164. Spanish Infertility SG, Checa MA, Bellver J, Bosch E, Espinos JJ, Fabregues F, Fontes J, Garcia-Velasco J, Requena A. Hysteroscopic septum resection and reproductive medicine: A SWOT analysis. Reprod Biomed Online 2018; 37: 709-715.

165. Ludwin A, Ludwin I, Coelho Neto MA, Nastri CO, Bhagavath B, Lindheim SR, Martins WP. Septate uterus according to ESHRE/ESGE, ASRM and CUME definitions: association with infertility and miscarriage, cost and warnings for women and healthcare systems. Ultrasound Obstet Gynecol 2019; 54: 800-814.

166. Ludwin A, Martins WP, Bhagavath B, Lindheim SR. Overdiagnosis, overdetection, and overdefinition of the septate uterus: reexamination of the ASRM and ESHRE-ESGE criteria is urgently needed. Fertil Steril 2019; 112: 448-449.

167. Ludwin A, Martins WP. Uterine 'anomalies' by ESHRE/ESGE classification: are more than half of the women really sick? Ultrasound Obstet Gynecol 2020;

168. Rikken JFW, Kowalik CR, Emanuel MH, Bongers MY, Spinder T, de Kruif JH, Bloemenkamp KWM, Jansen FW, Veersema S, Mulders A, Thurkow AL, Hald K, Mohazzab A, Khalaf Y, Clark TJ, Farrugia M, van Vliet 
HA, Stephenson MS, van der Veen F, van Wely M, Mol BWJ, Goddijn M. The randomised uterine septum transsection trial (TRUST): design and protocol. BMC Womens Health 2018; 18: 163.

169. NICE. Fertility problems: assessment and treatment. NICE guidelines. London; 2017.

170. Ford HB, Schust DJ. Recurrent pregnancy loss: etiology, diagnosis, and therapy. Rev Obstet Gynecol 2009; 2: 76-83.

171. Zeitlin J, Szamotulska K, Drewniak N, Mohangoo AD, Chalmers J, Sakkeus L, Irgens L, Gatt M, Gissler M, Blondel B, Euro-Peristat Preterm Study G. Preterm birth time trends in Europe: a study of 19 countries. BJOG 2013; 120: 1356-1365.

172. Ludwin A, Martins WP, Ludwin I. Uterine cavity imaging, volume estimation and quantification of degree of deformity using automatic volume calculation: description of technique. Ultrasound Obstet Gynecol 2017; 50: 138-140. 
Figure 1: Flowchart of the study selection

Electronic search $(n=2,504)$

Manual search $(n=31)$

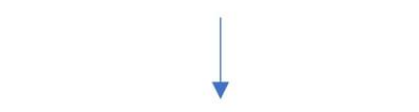

Total $=2,535$
- Duplicates removed $(n=729)$
- Screened after duplicates removed $(n=1,806)$

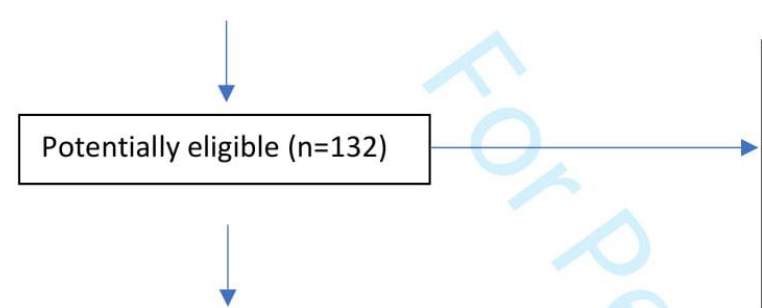

Included in this review $(n=20)$
Clearly did not meet eligibility criteria by screening titles/abstracts $(n=1674)$

Excluded $(n=112)$

- T-shaped uterus related to DES $(n=64)$

- Not related to T-shaped uterus $(n=26)$

- Less than 10 women with T-shaped $(n=15)$

- No results for T-shaped $(n=4)$

- Descriptive review $(n=3)$ 


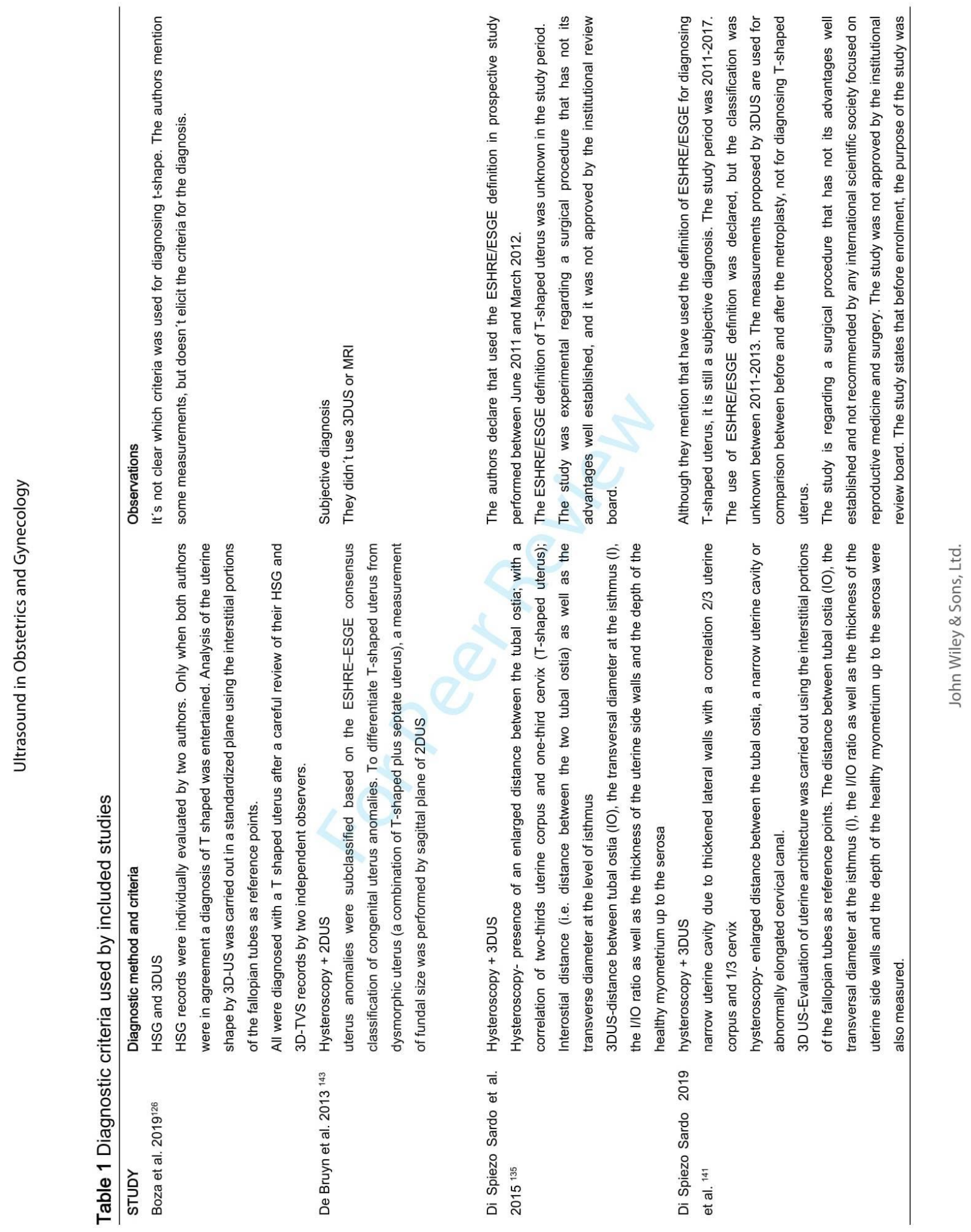

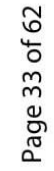




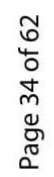

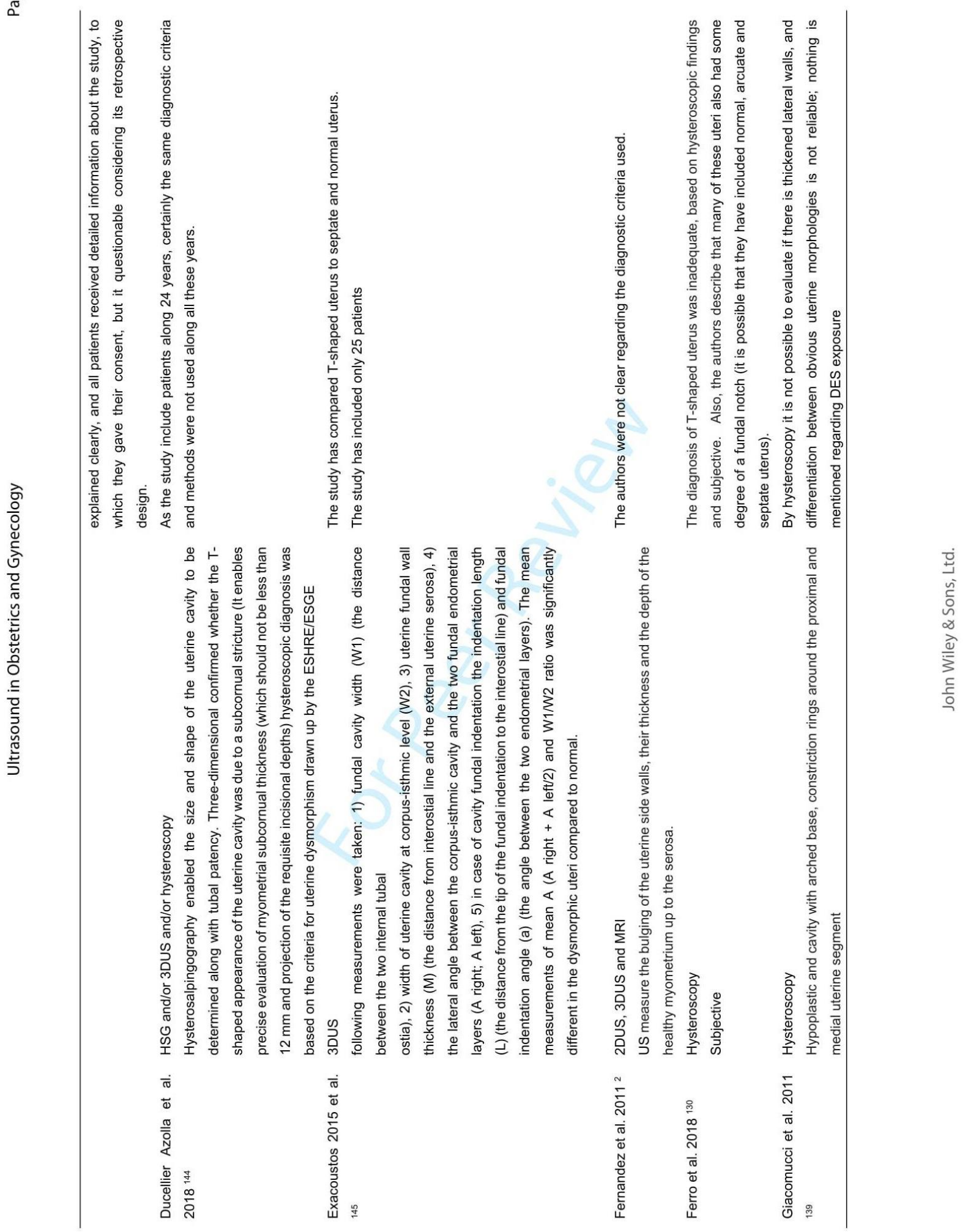




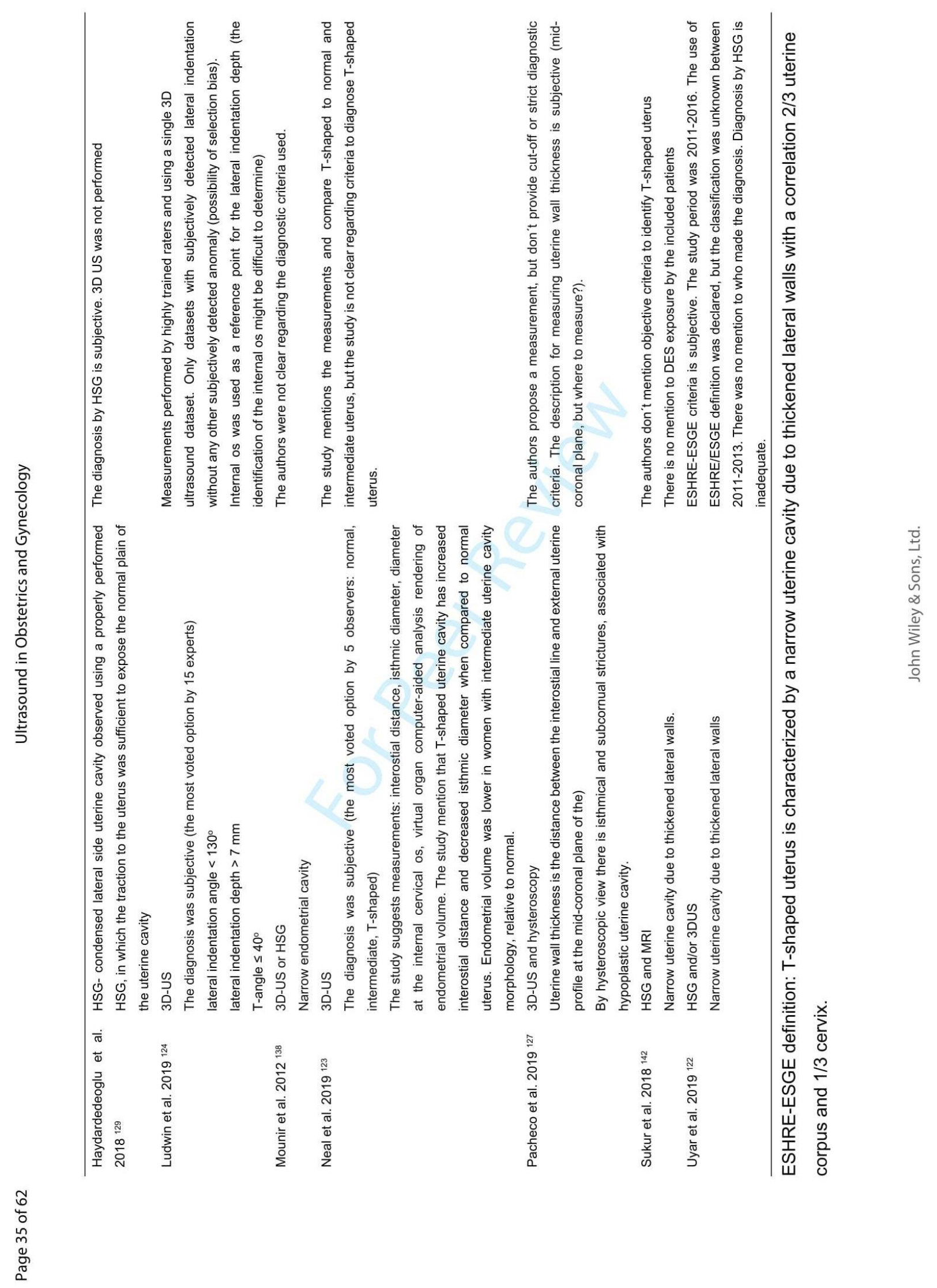




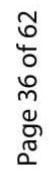

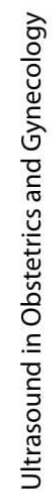




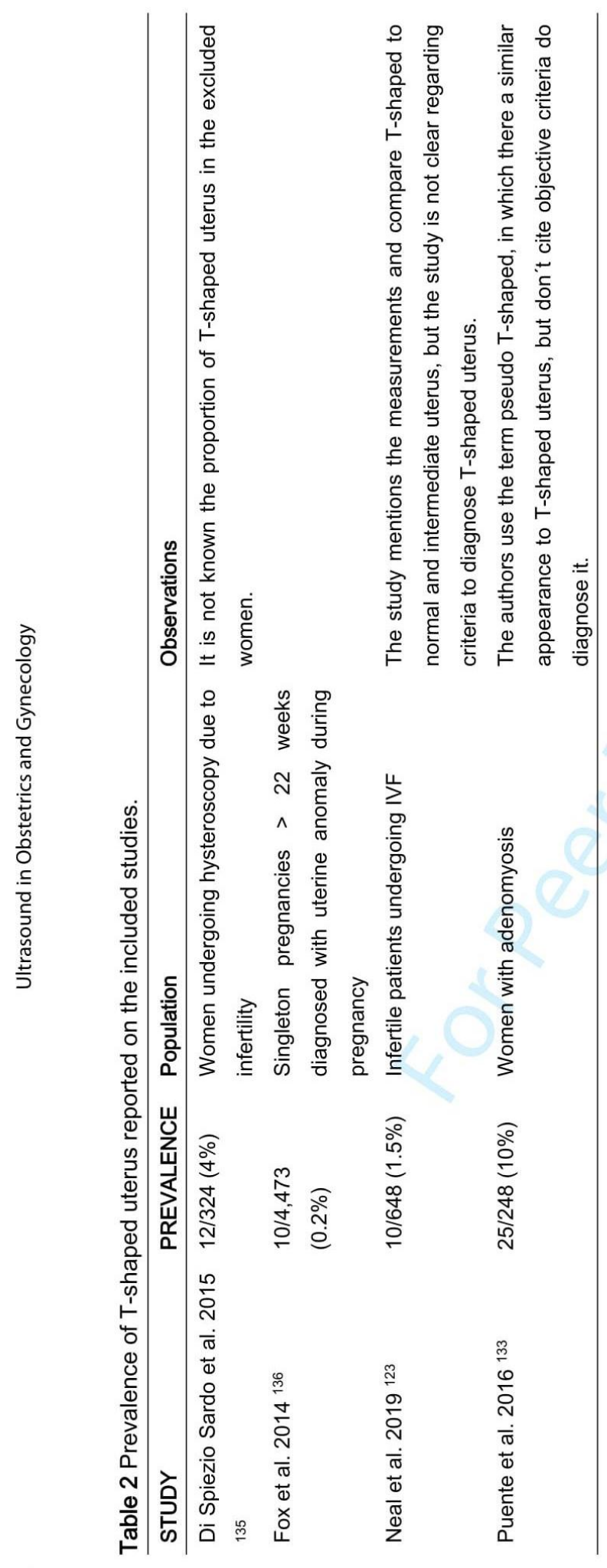




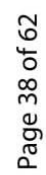

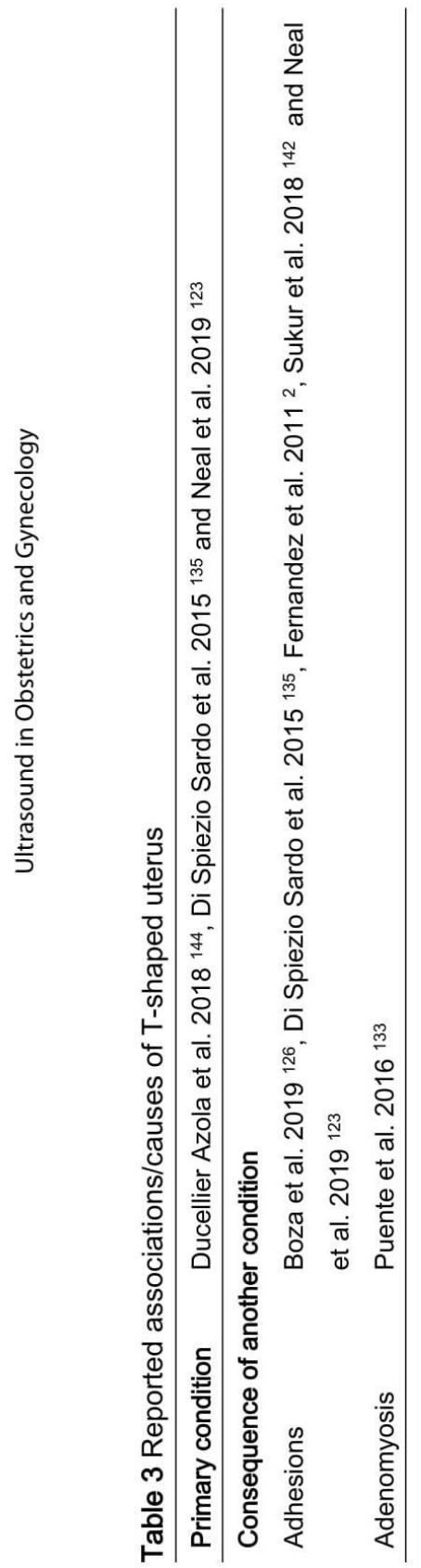


Table 4 Association of T-shaped uterus with clinical conditions.

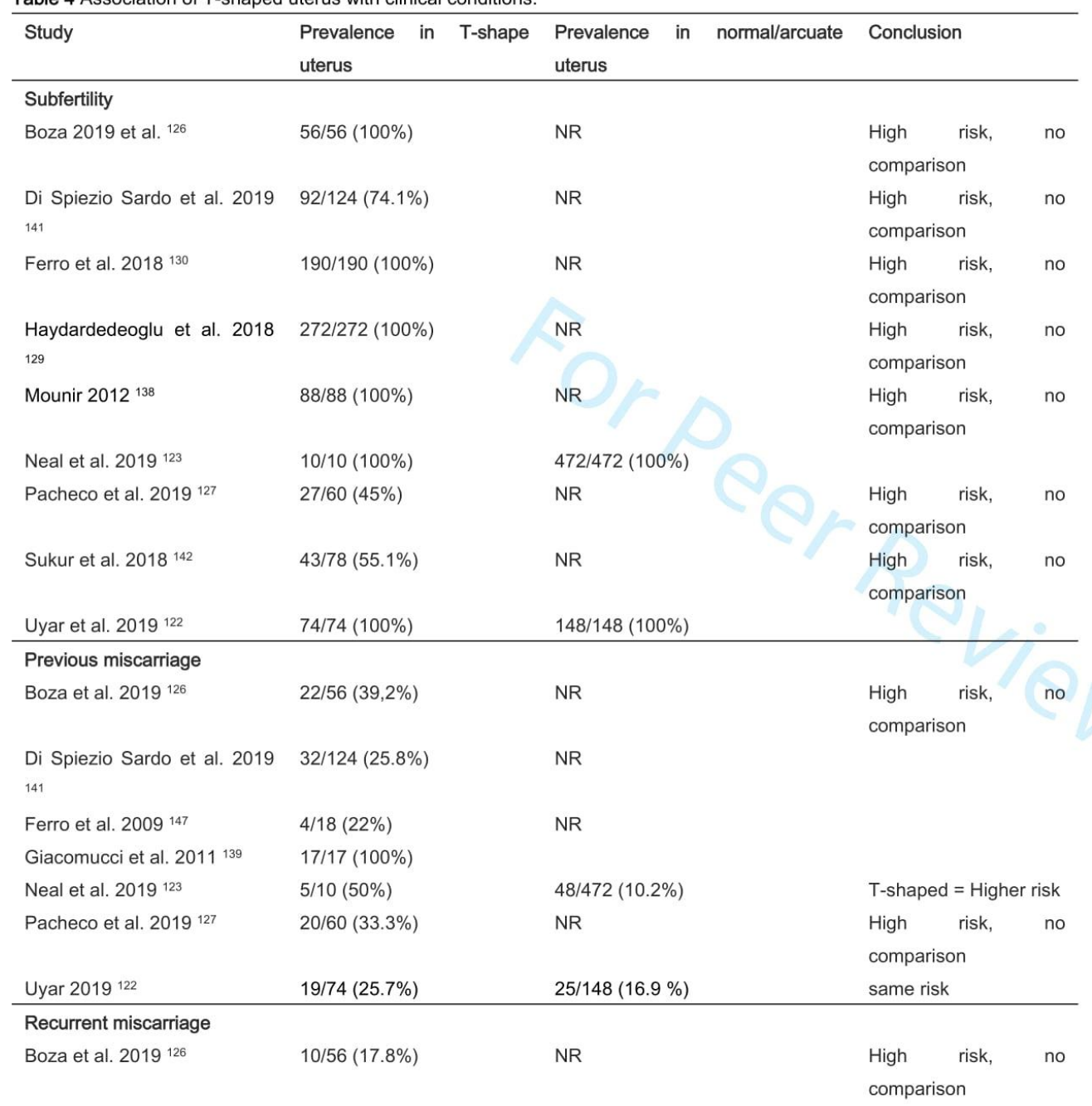




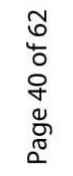

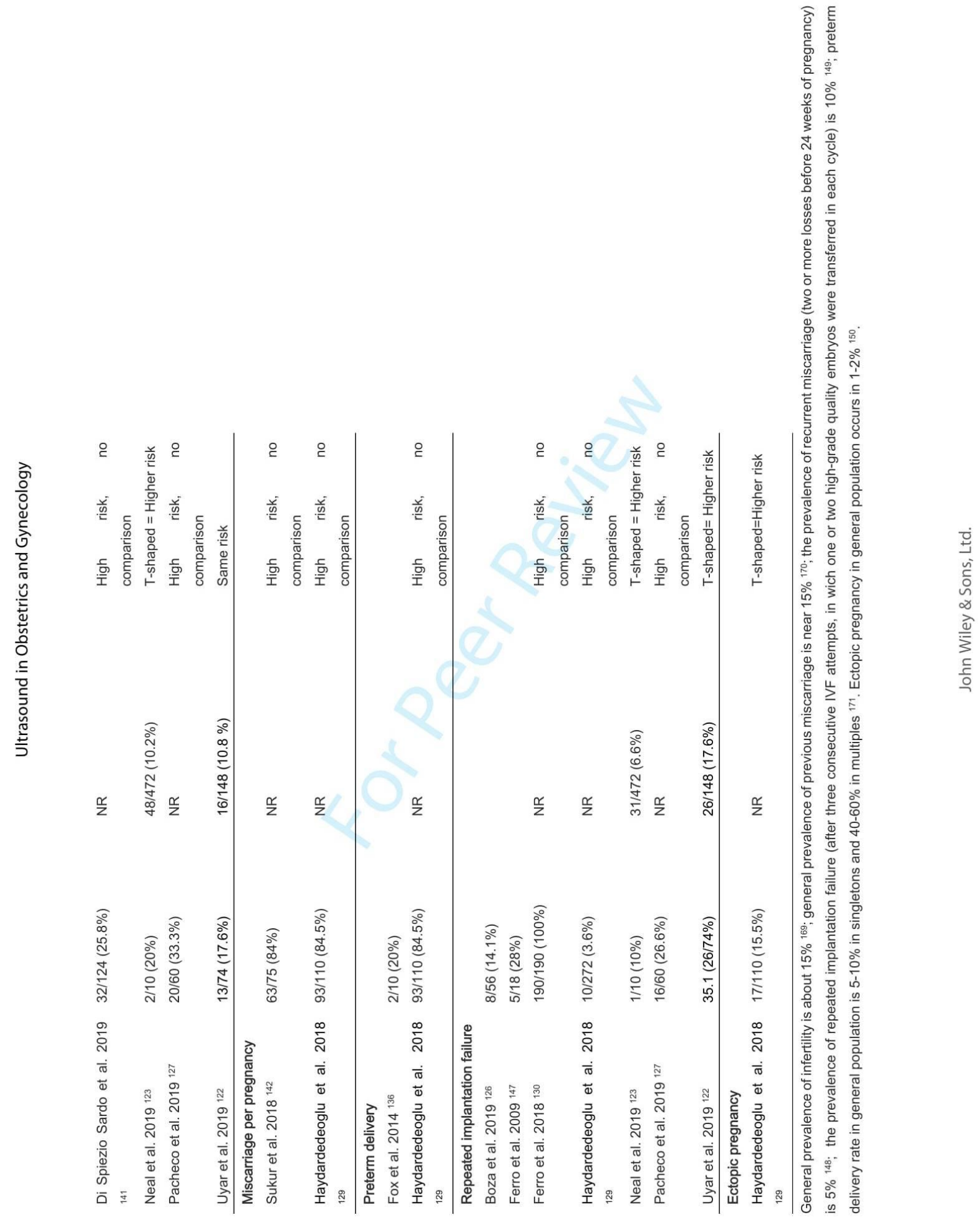




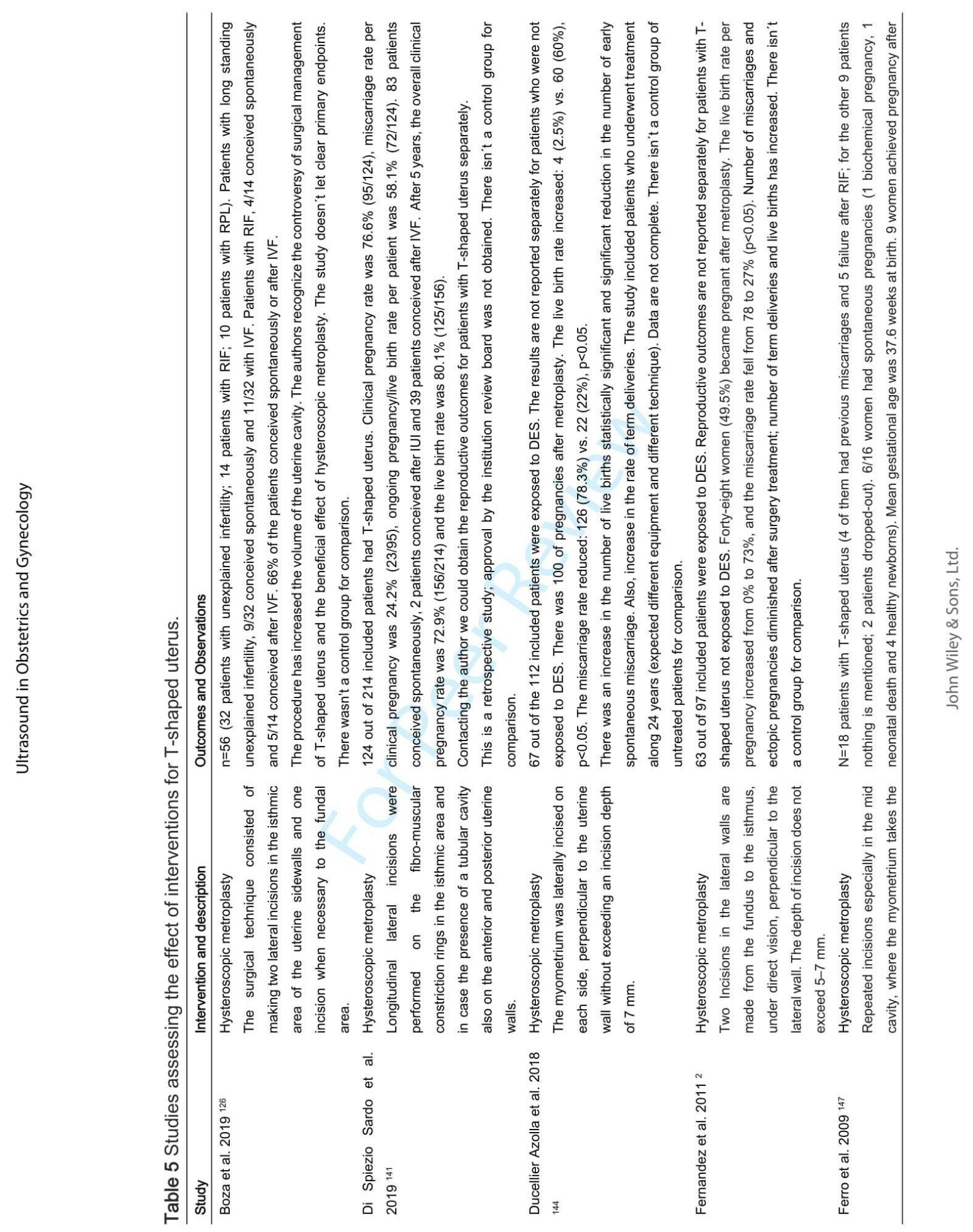

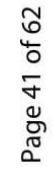




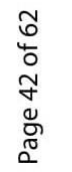

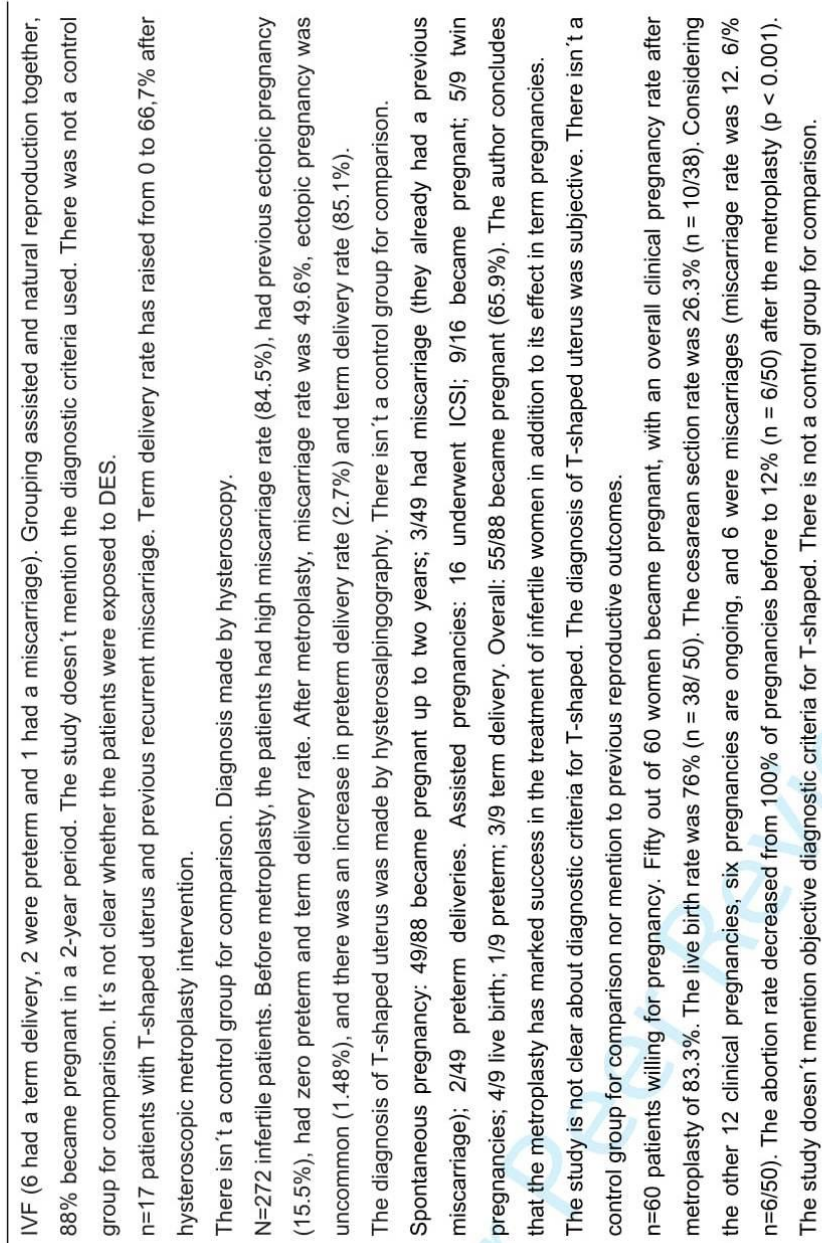

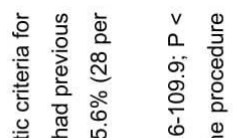

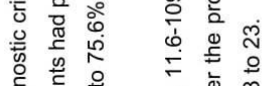

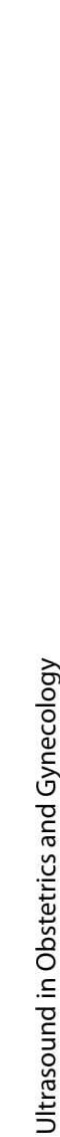

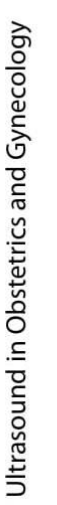

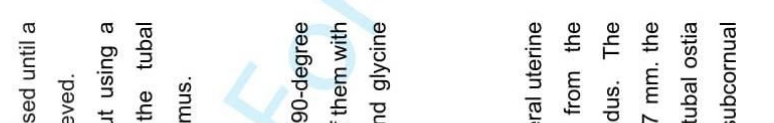

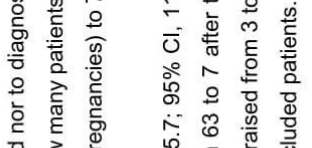

总产产

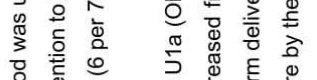

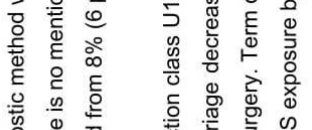

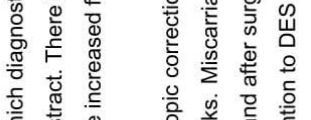

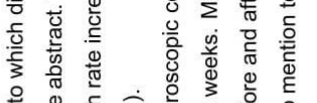

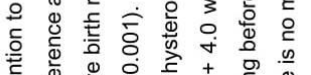

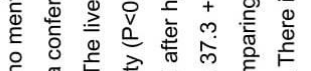

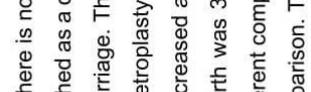

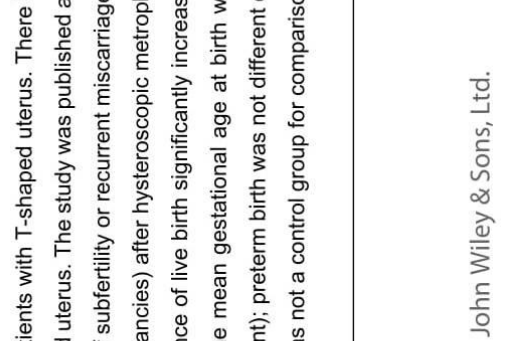

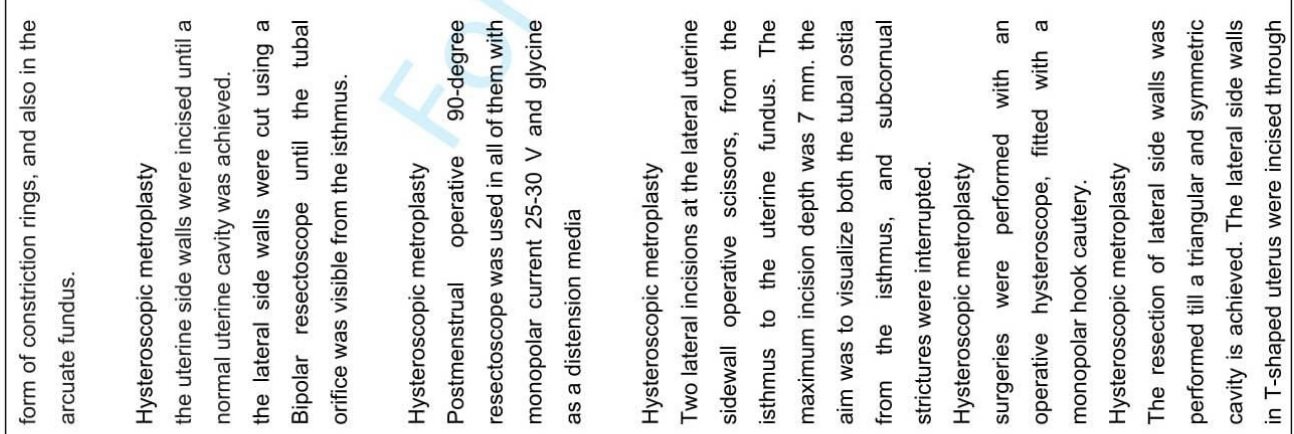

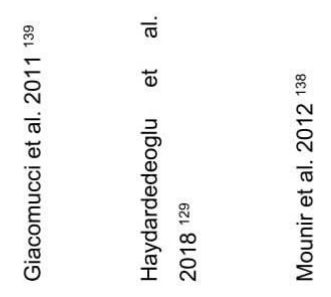

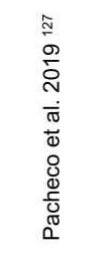

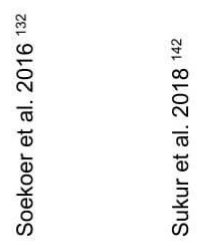




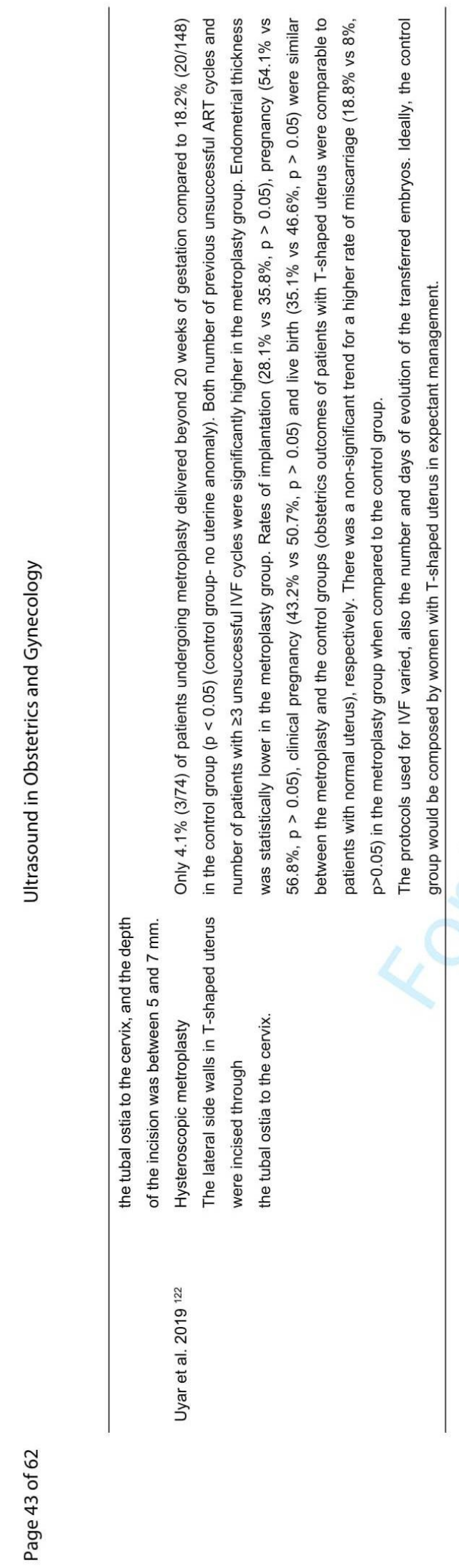




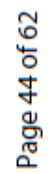

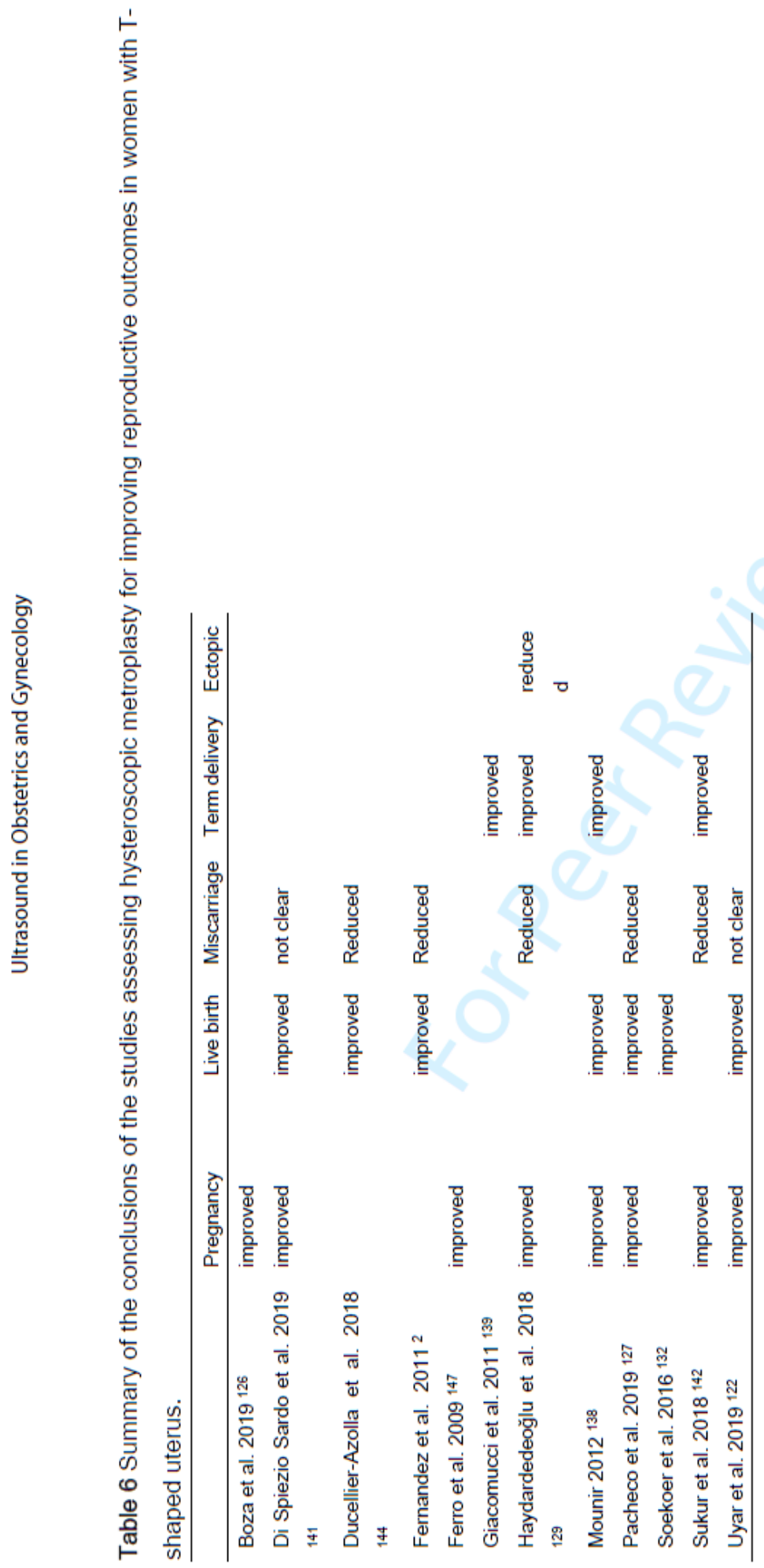




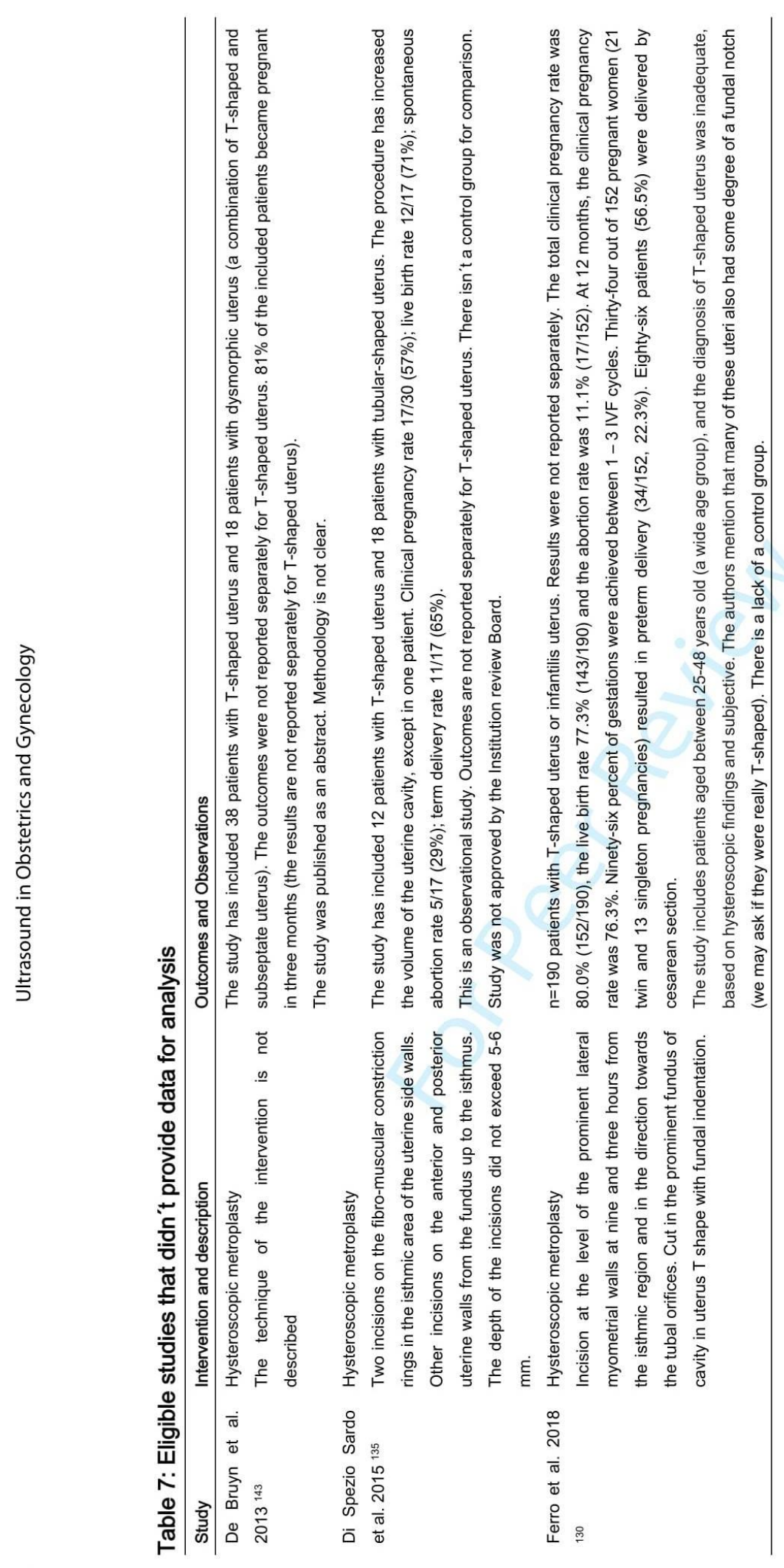




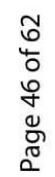

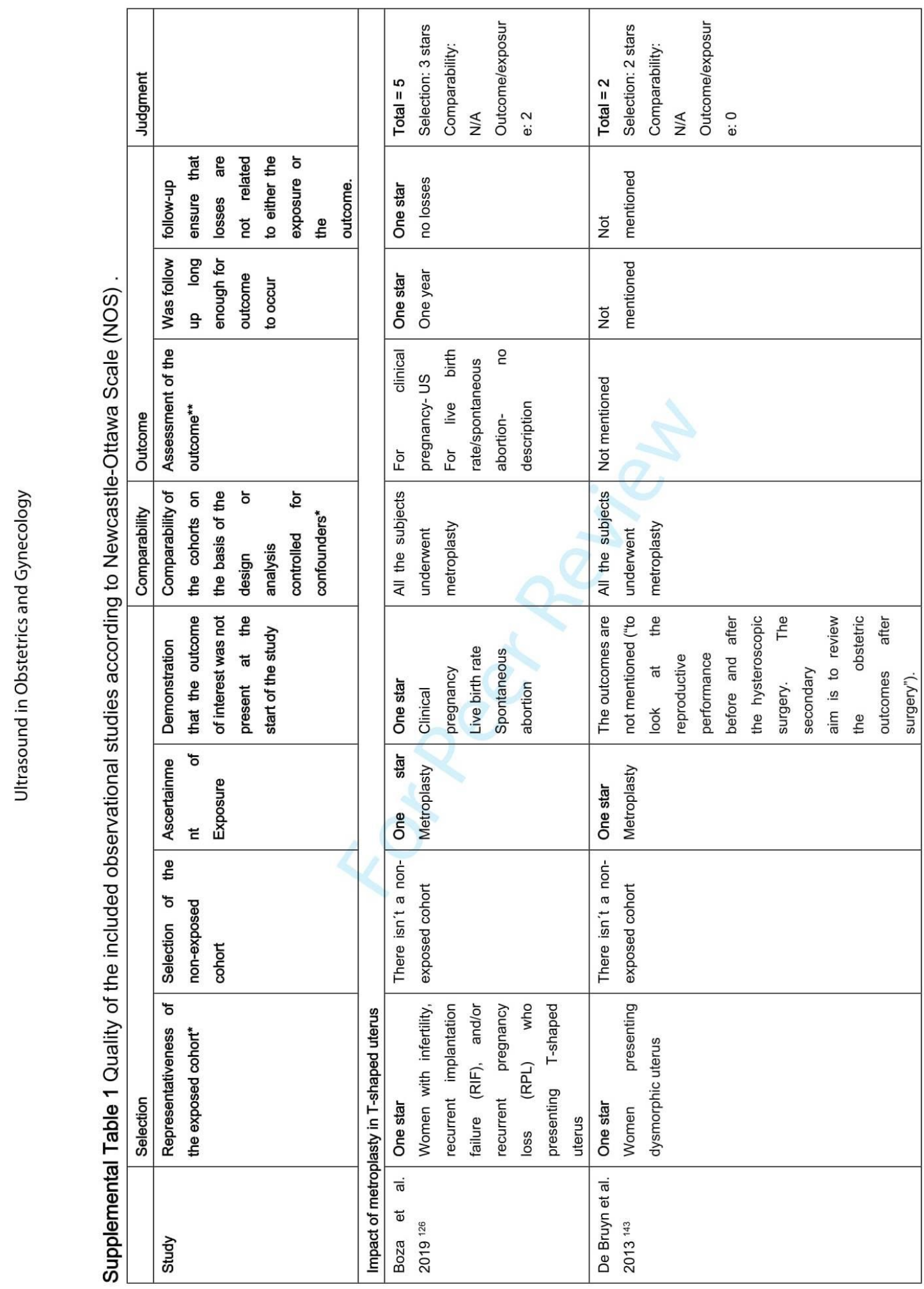




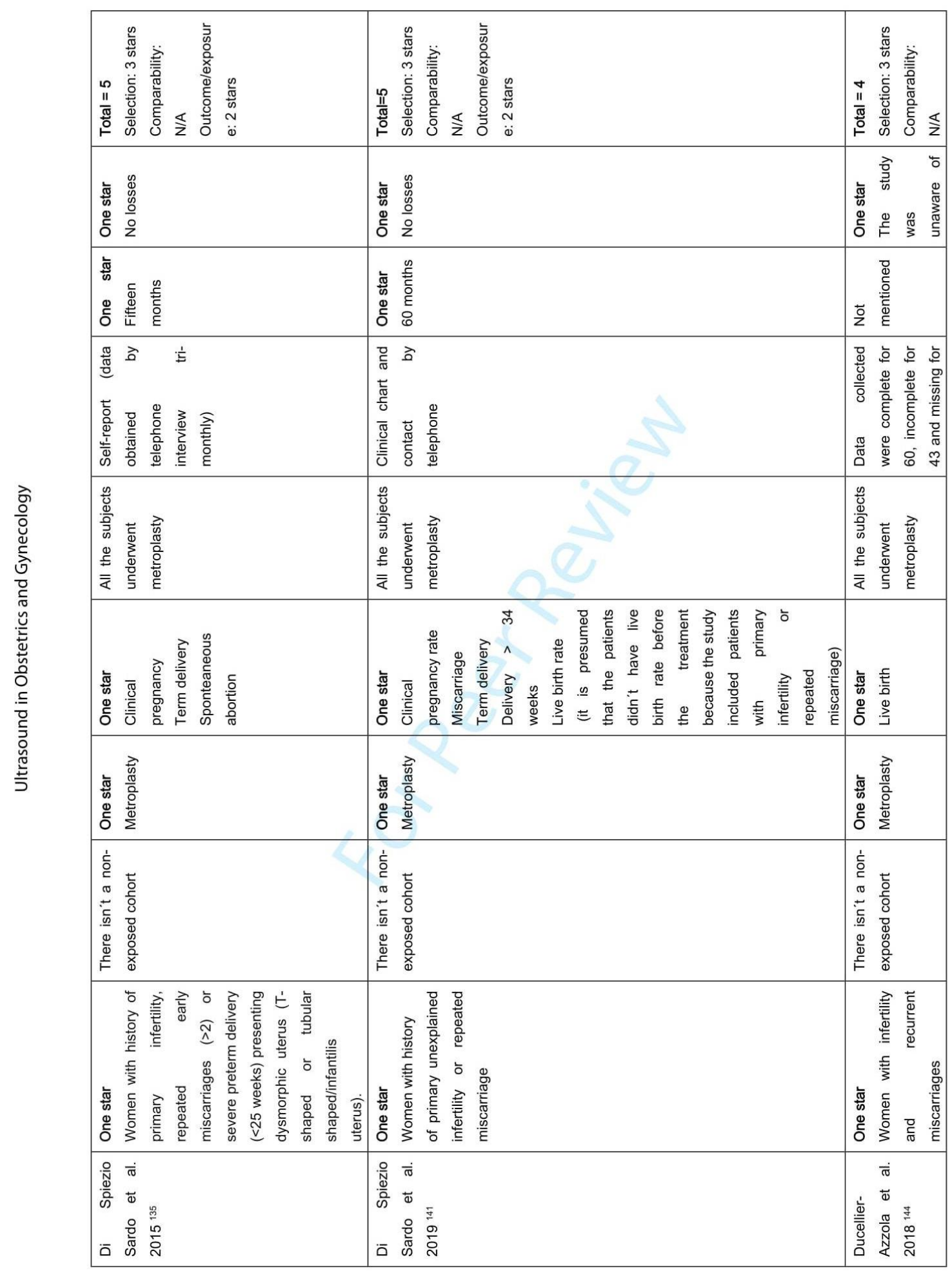




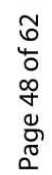

\begin{tabular}{|c|c|c|c|}
\hline 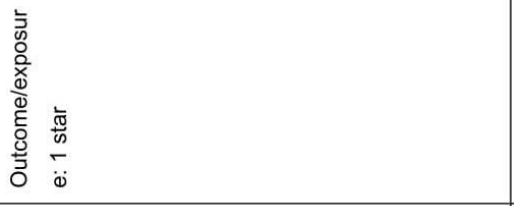 & 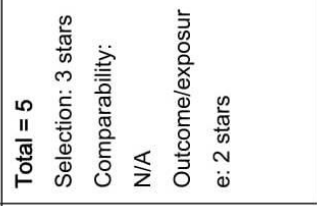 & 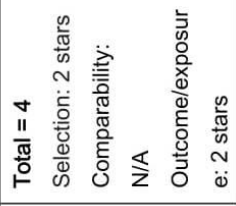 & 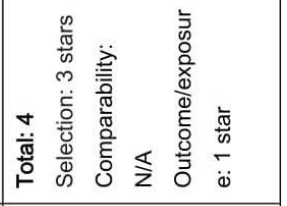 \\
\hline 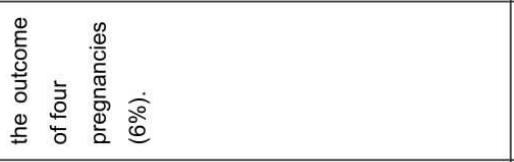 & 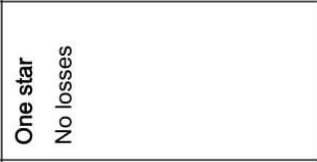 & 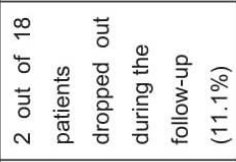 & 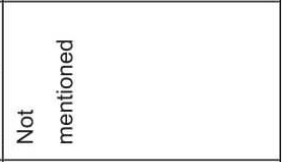 \\
\hline & 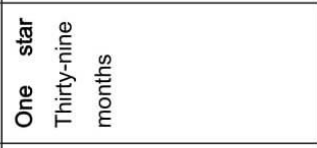 & 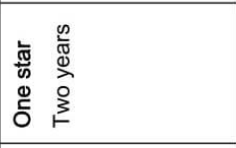 & 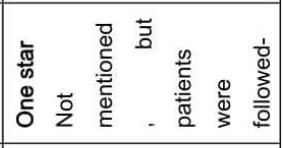 \\
\hline 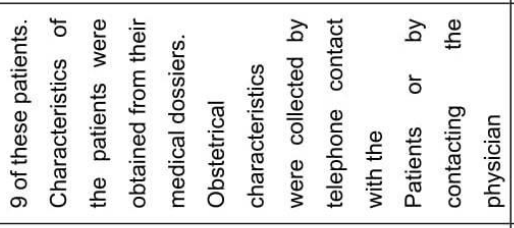 & 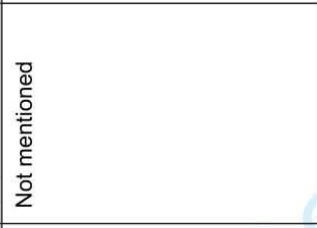 & 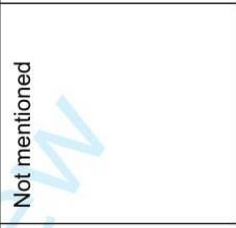 & 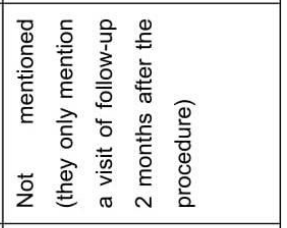 \\
\hline & 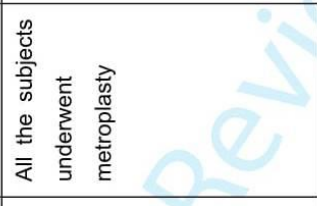 & 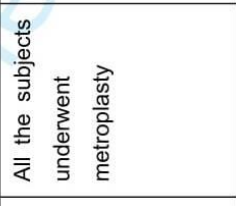 & 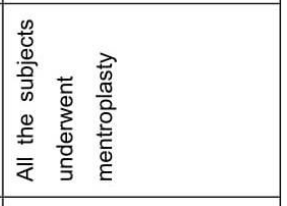 \\
\hline 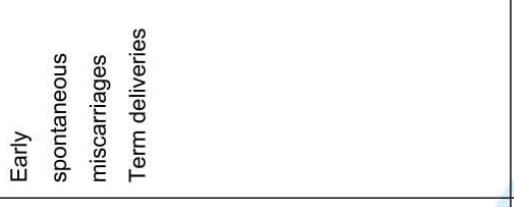 & 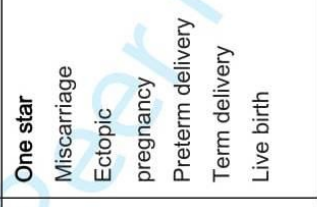 & 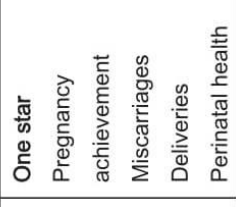 & 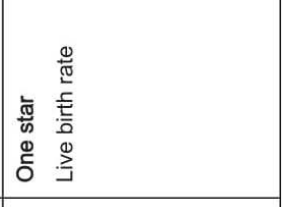 \\
\hline & 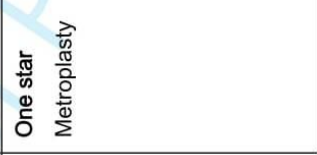 & 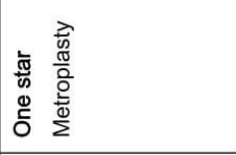 & 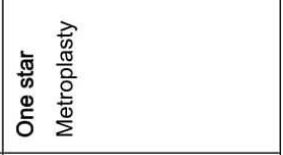 \\
\hline & 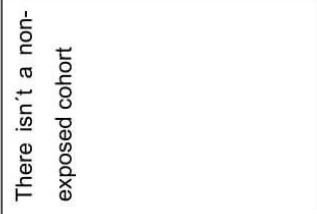 & 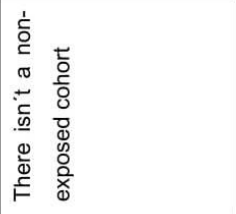 & 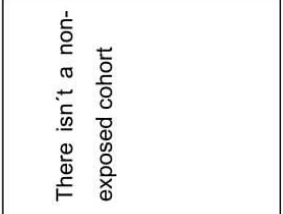 \\
\hline 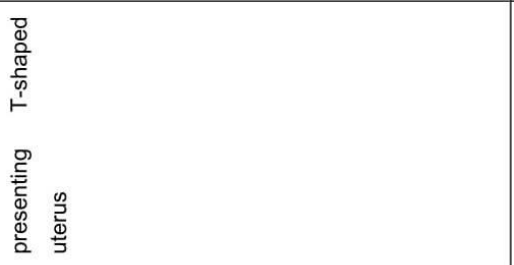 & 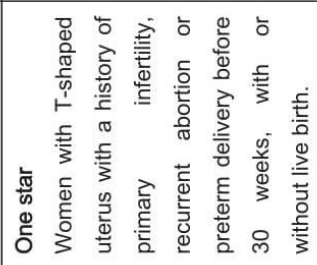 & 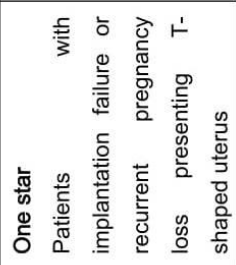 & 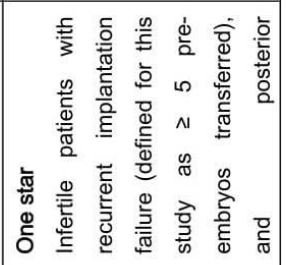 \\
\hline & 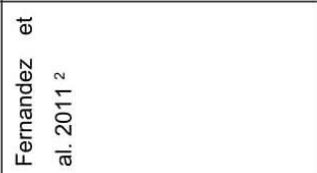 & 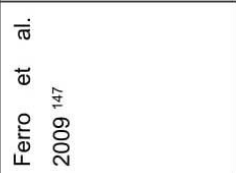 & 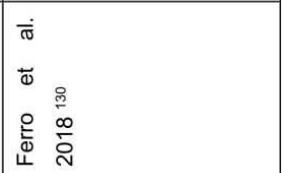 \\
\hline
\end{tabular}




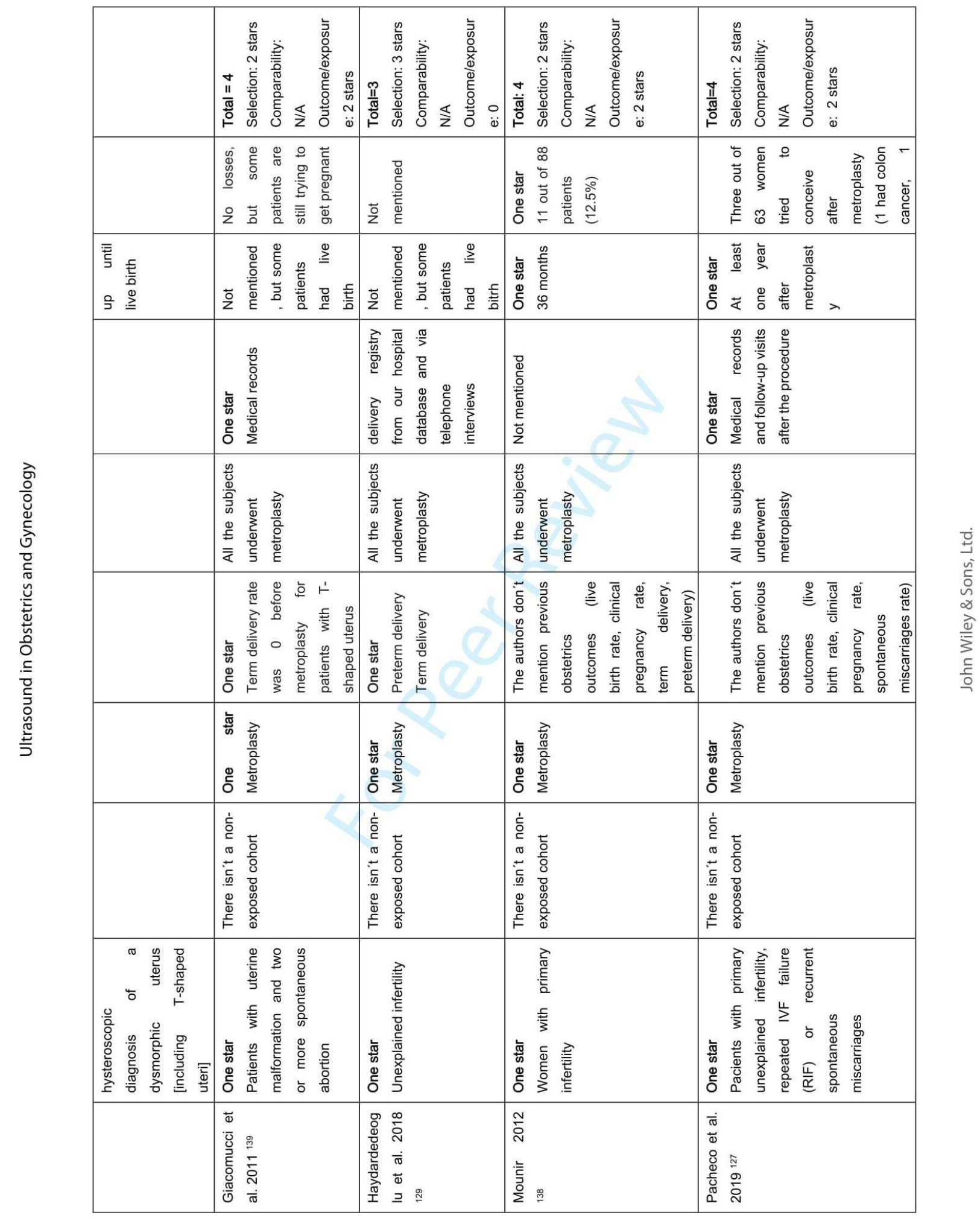

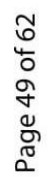


0
6
$\circ$
0
0
0
0
0

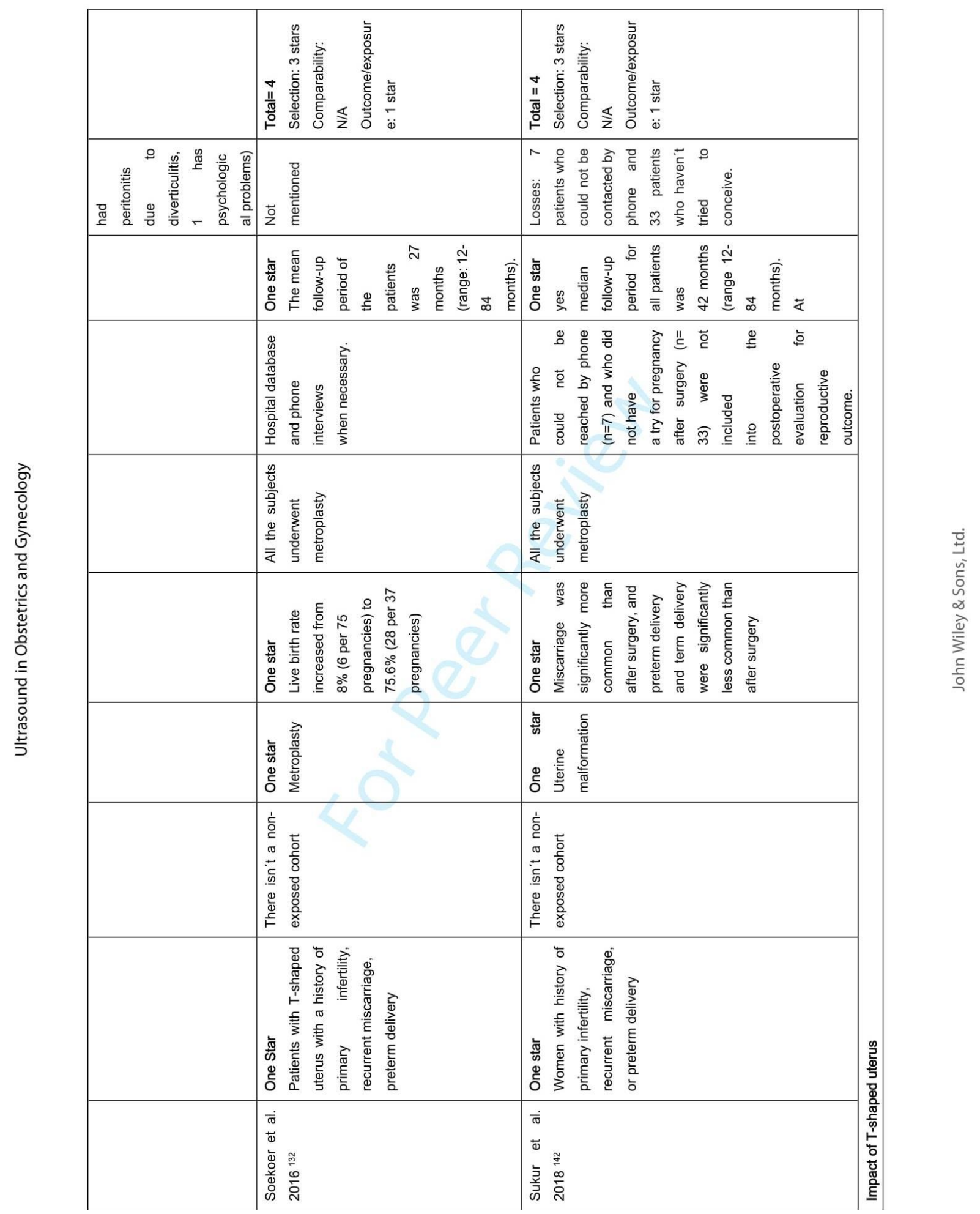




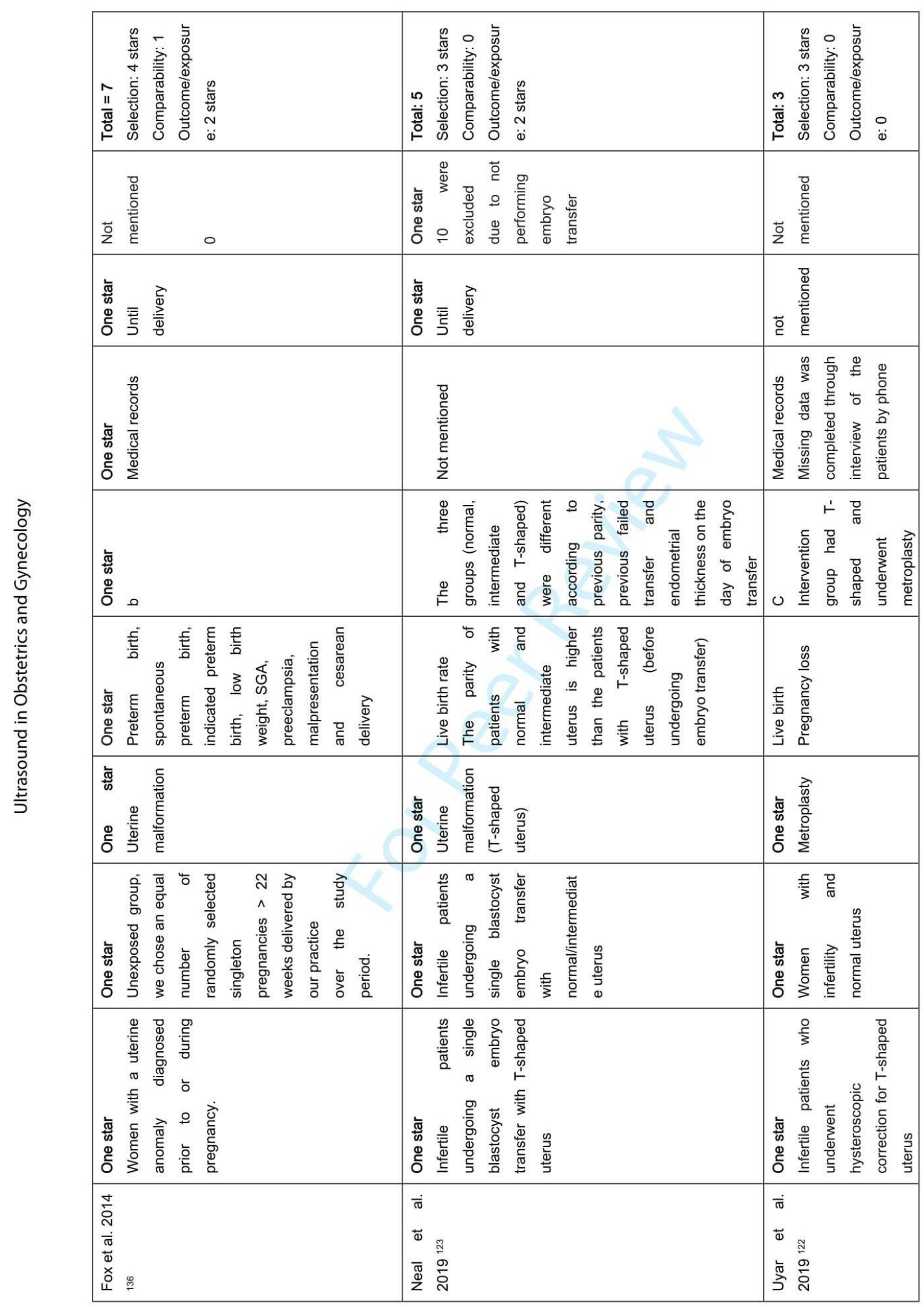




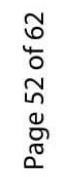

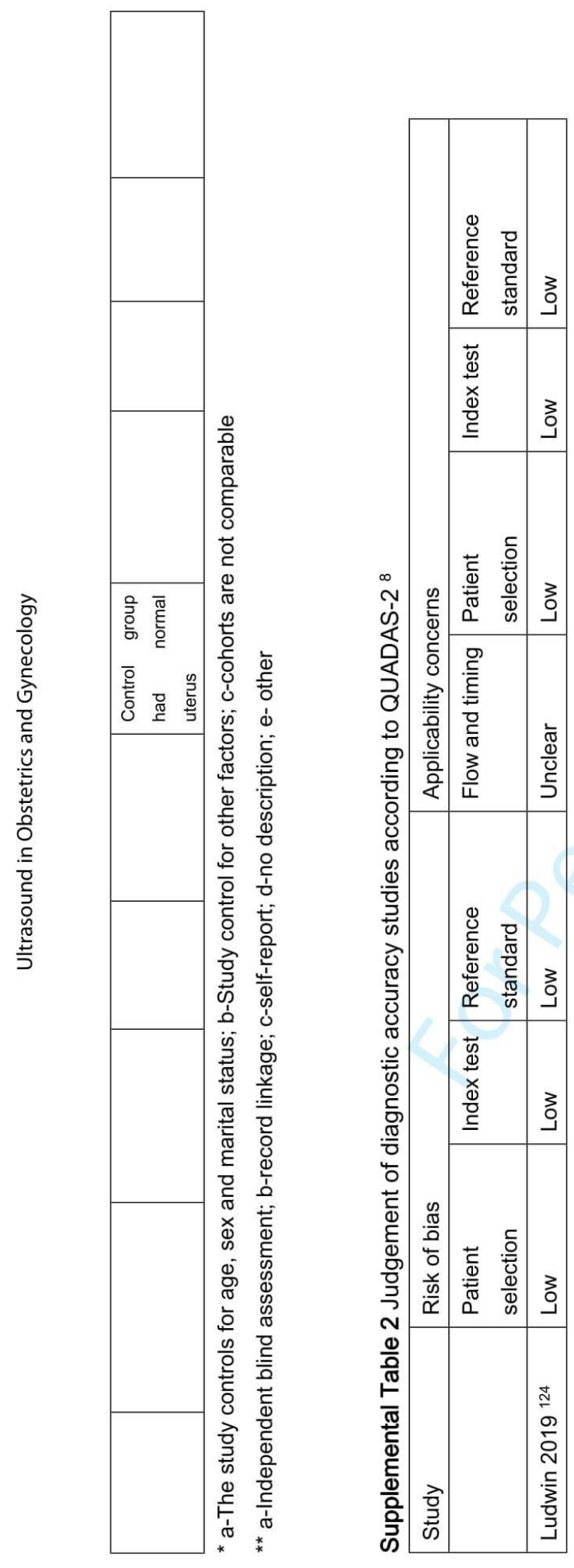




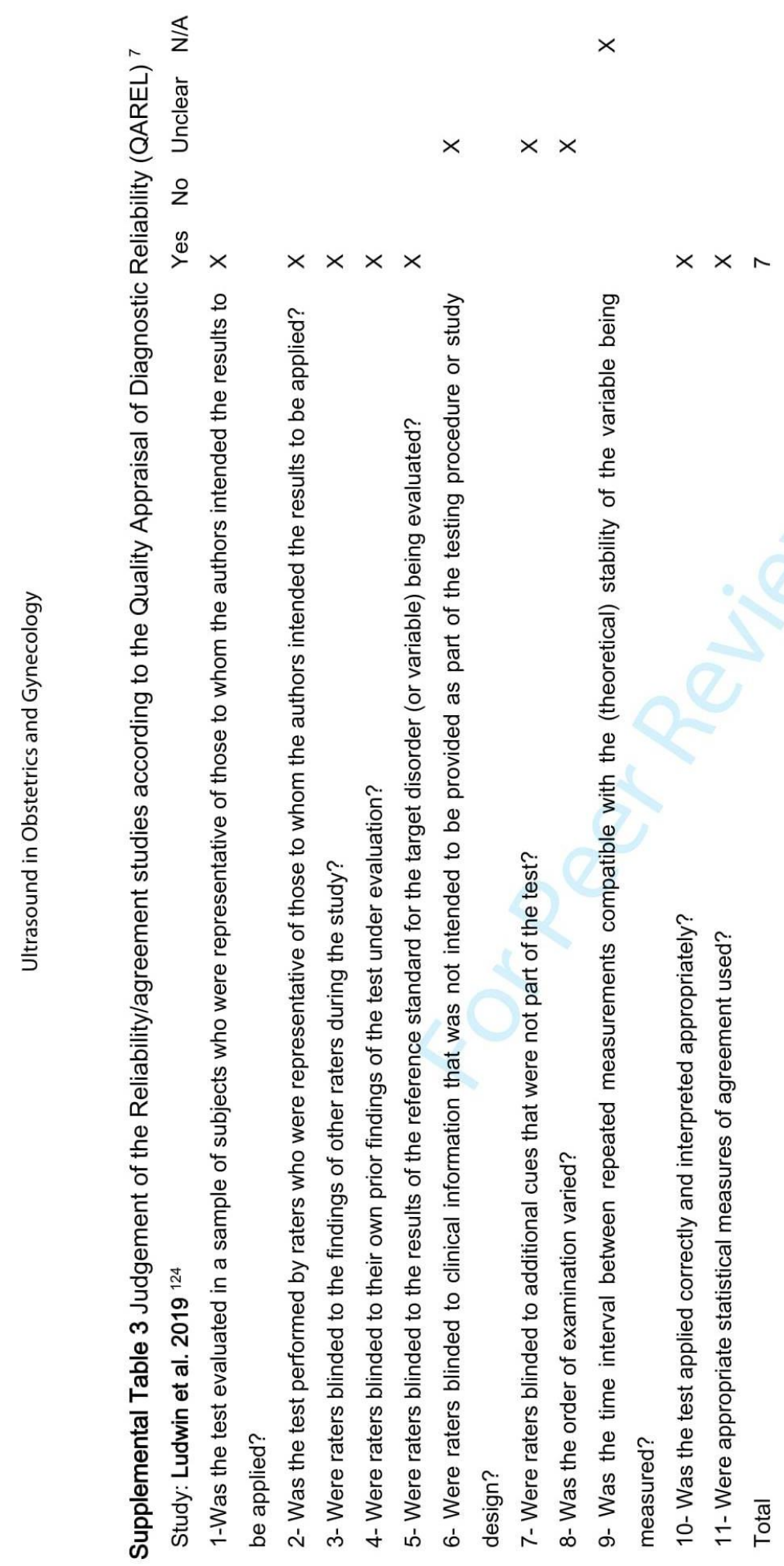

0
0
0
0
0
0
0
0
0 
0
0
0
$\vdots$
0
0
0
0
0

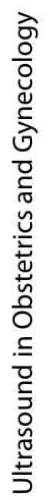




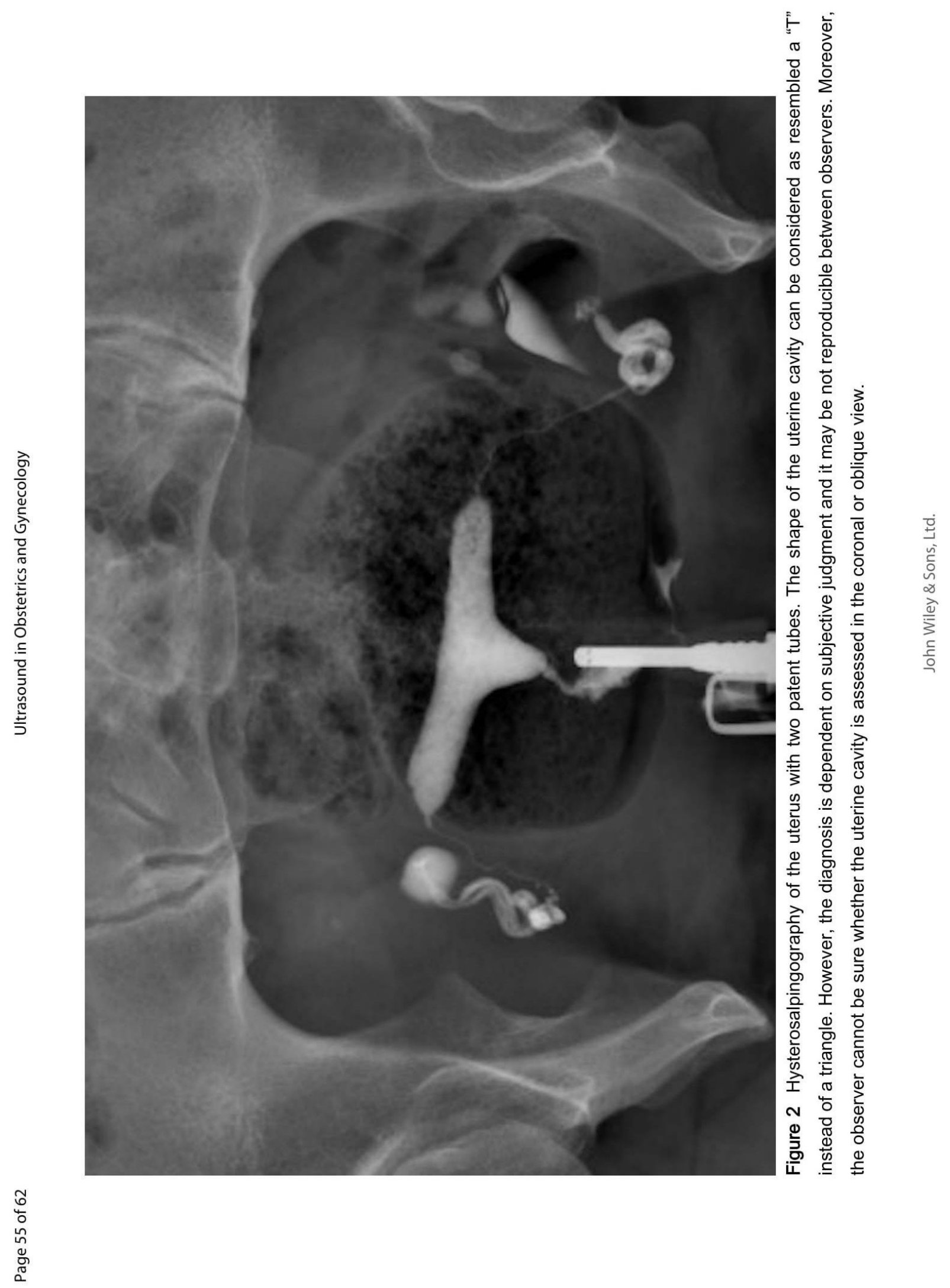




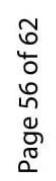

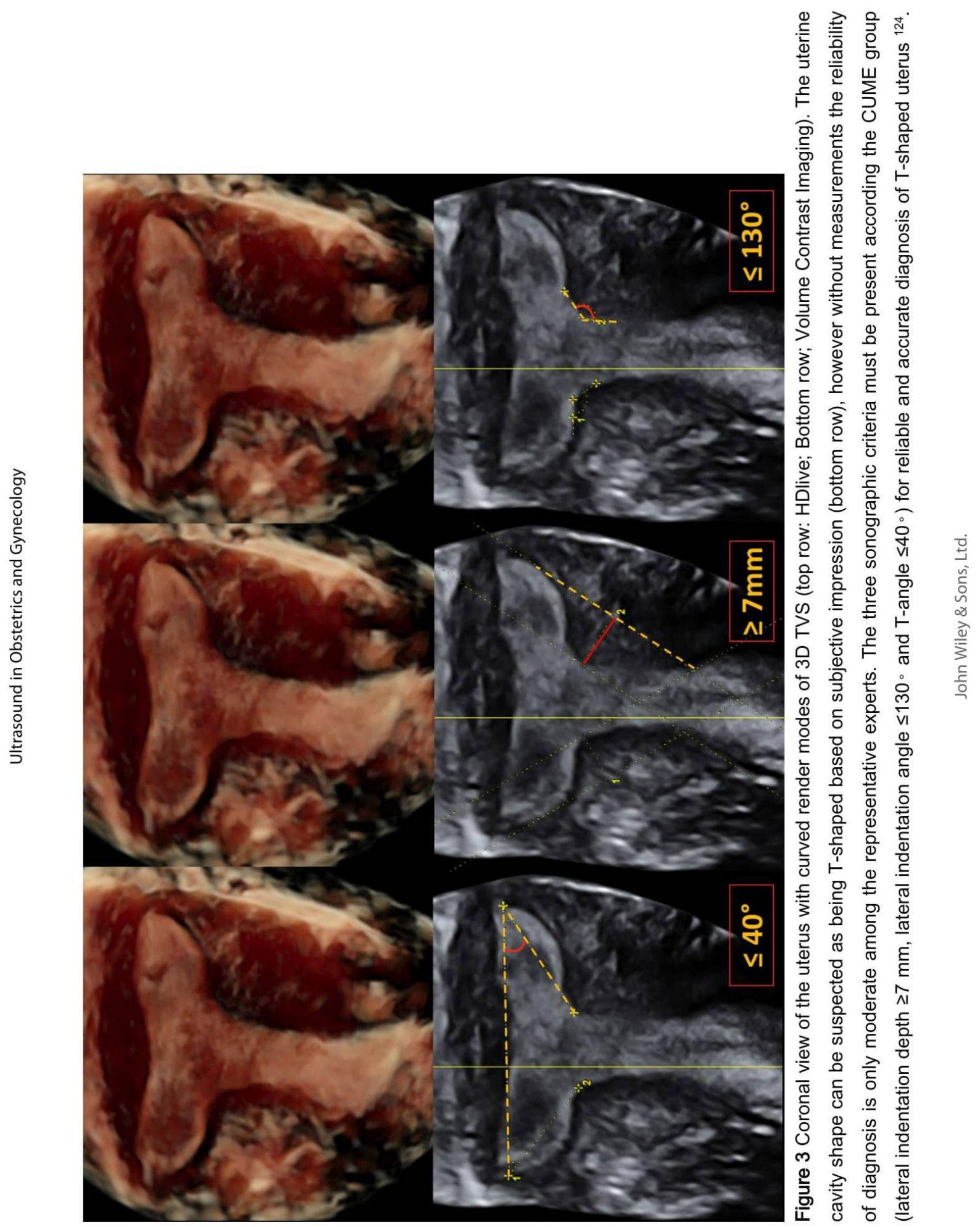




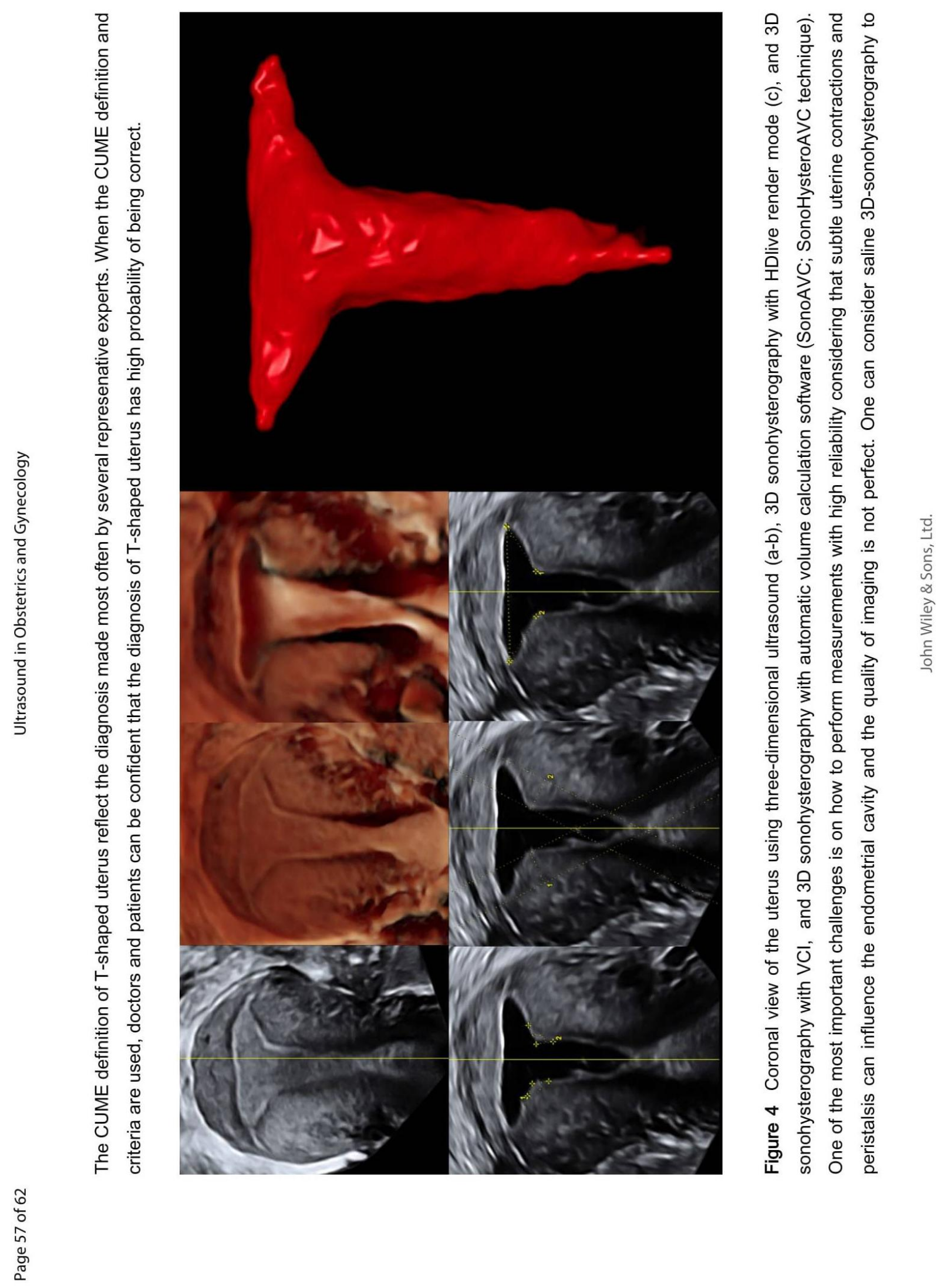




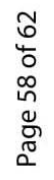

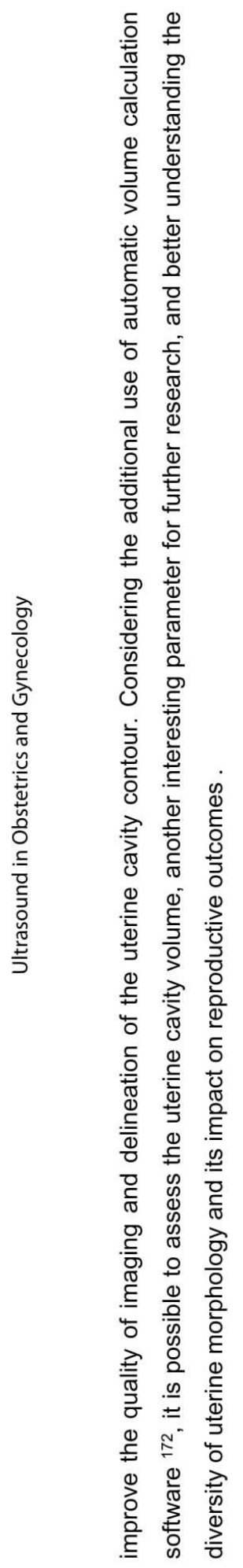




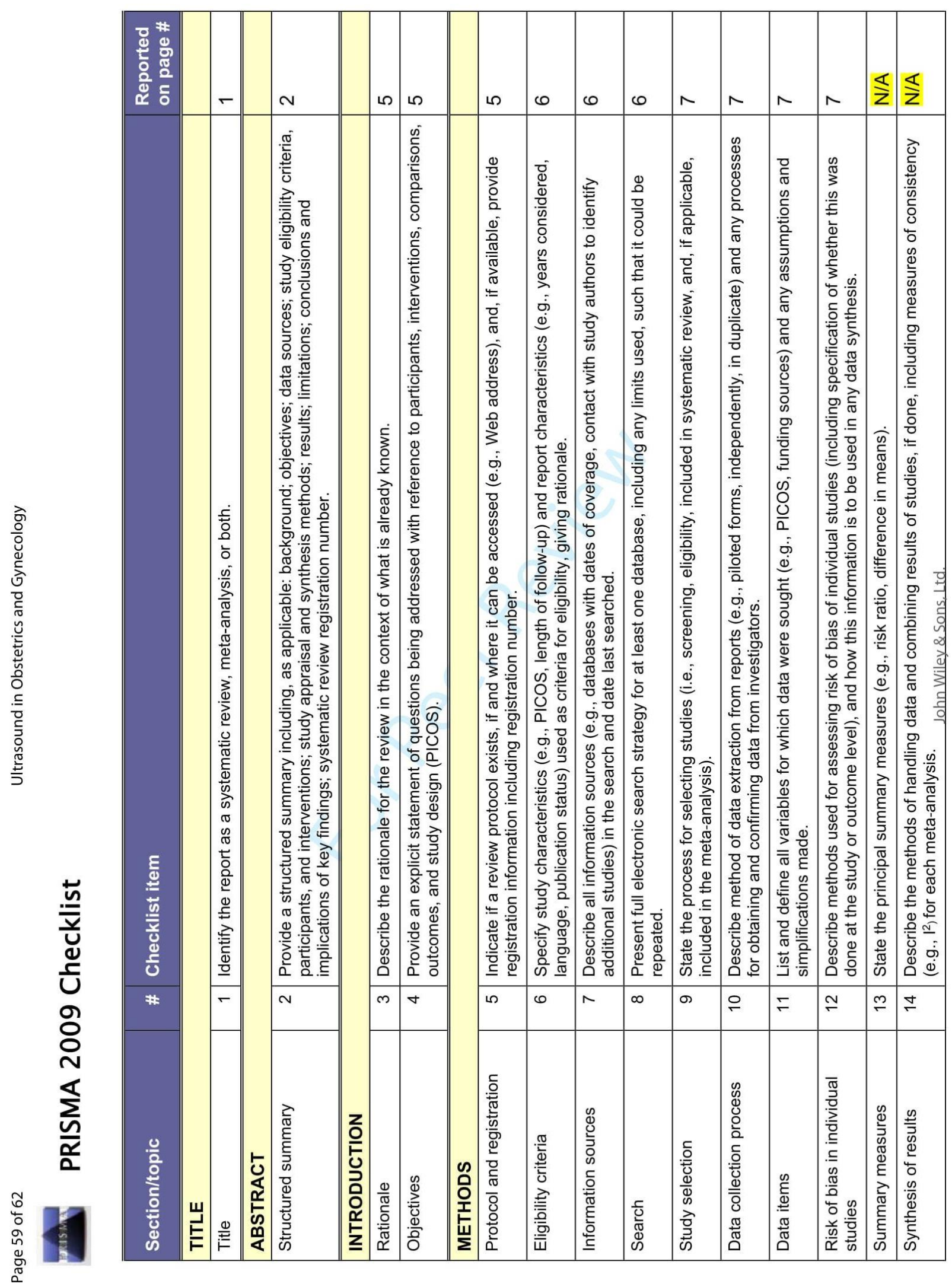



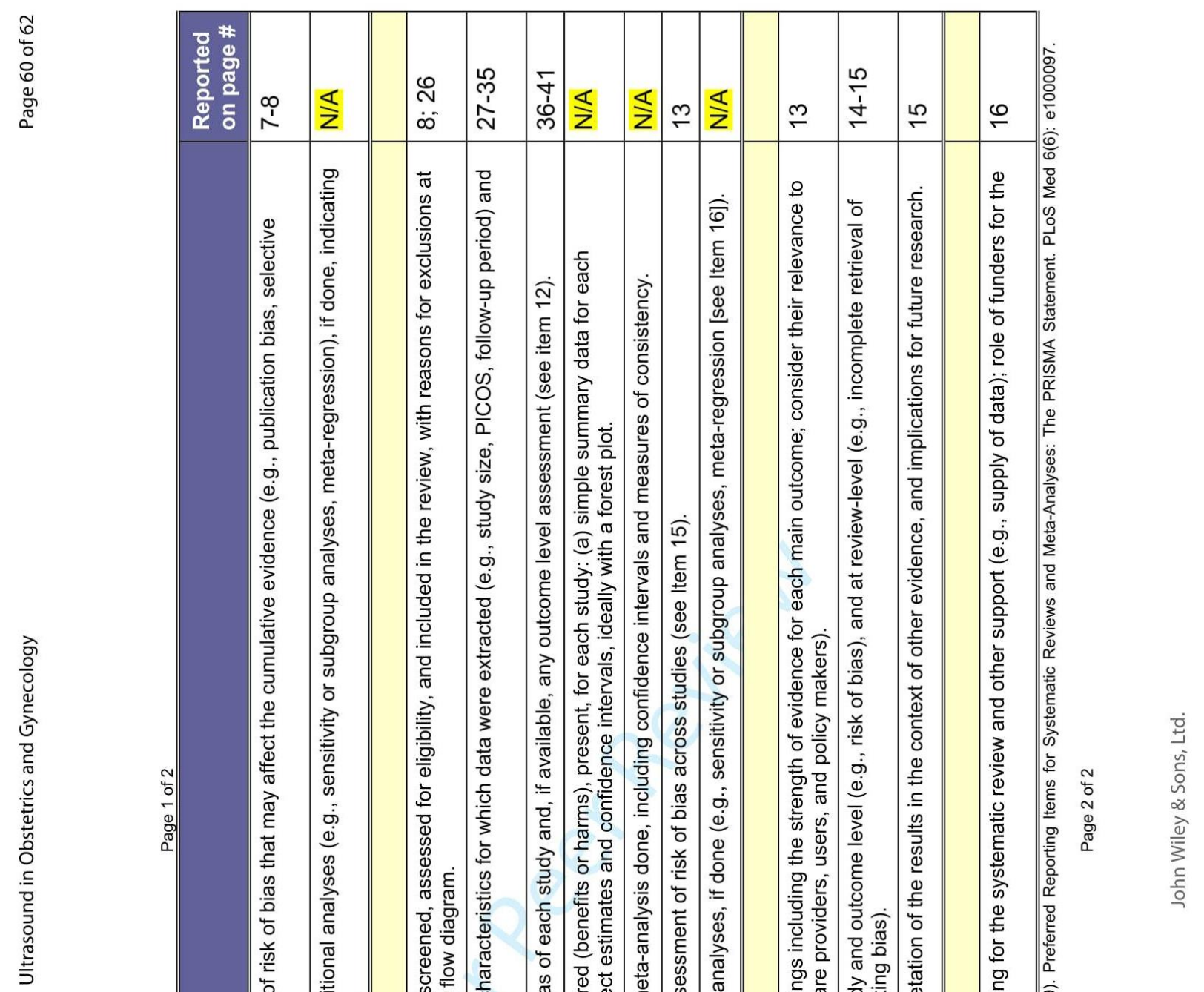
Dear Mrs Coelho Neto,

Thank you for submitting details of your systematic review "Definitions, prevalence, clinical implications and the treatment of the T-shaped uterus: a systematic review" to the PROSPERO register. We are pleased to confirm that the record will be published on our website within the next hour.

Your registration number is: CRD42019115131

You are free to update the record at any time, all submitted changes will be displayed as the latest version with previous versions available to public view. Please also give brief details of the key changes in the Revision notes facility and remember to update your record when your review is published. You can log in to PROSPERO and access your records at https://www.crd.york.ac.uk/PROSPERO.

Comments and feedback on your experience of registering with PROSPERO are welcome at crd-register@york.ac.uk

Is your team looking for a platform to conduct data extraction for your systematic review? SRDR-Plus is a free, powerful, easy-to-use systematic review data management and archival tool. You can get started here: http://srdrplus.ahrq.gov.

Best wishes for the successful completion of your review.

Yours sincerely,

PROSPERO Administrator

Centre for Reviews and Dissemination

University of York

York Y010 5DD

t: +44 (0) 1904321049

e: CRD-register@york.ac.uk

www.york.ac.uk/inst/crd

PROSPERO is funded by the National Institute for Health Research and produced by CRD, which is an academic department of the University of York.

Email disclaimer: https://www.york.ac.uk/docs/disclaimer/email.htm 
PROSPERO

This information has been provided by the named contact for this review. CRD has accepted this information in good faith and registered the review in PROSPERO. CRD bears no responsibility or liability for the content of this registration record, any associated files or external websites. 
4. Discussão 
Mesmo entre observadores bem treinados, o nível de concordância para o diagnóstico do útero em "T" por meio de avaliação subjetiva do corte coronal do útero no estudo CUME foi apenas moderado, e o percentual de concordância foi de $80 \%$. O estudo identificou três medidas com boa precisão e reprodutibilidade de razoável a moderada para o diagnóstico objetivo do útero em formato de "T": ângulo de endentação lateral $\left(<130^{\circ}\right)$, profundidade da endentação lateral ( $>7 \mathrm{~mm}$ ) e ângulo "T" $\left(\leq 40^{\circ}\right)$. Na presença dos três critérios, é possível que haja melhor concordância com a opinião mais votada pelos especialistas. Este é o primeiro estudo a propor critérios diagnósticos objetivos e mensuráveis para o útero em "T".

Os estudos incluídos na revisão sistemática sobre útero em "T" utilizaram diferentes critérios para o diagnóstico desta condição. Além disso, os autores mencionaram diferentes métodos diagnósticos, sendo o US-3D o mais citado. Como as pacientes incluídas nos estudos têm antecedente de infertilidade, abortamento, parto pré-termo, falha de implantação e gravidez ectópica, interroga-se a associação do útero em formato de "T" a desfechos reprodutivos comprometidos. Nos estudos incluídos na revisão, sua prevalência variou de 0,2-10\%. As causas relacionadas ao útero em "T" foram sinéquias uterinas, adenomiose, além de ter sido citado como um defeito de causa primária. O tratamento cirúrgico do útero em "T" foi proposto por vários estudos, estando relacionado à melhora importante nos desfechos reprodutivos (taxa de gravidez e de nascido vivo, parto a termo, redução de abortamento e de gravidez ectópica). Entretanto, a qualidade da evidência é muito baixa. Nenhum dos estudos incluiu um grupo controle de pacientes em manejo expectante.

Usar critérios diagnósticos adequados para a definição do útero em "T" é tão importante quanto escolher um método diagnóstico adequado. O estudo CUME contribui para o desenvolvimento de uma linguagem comum no diagnóstico das malformações uterinas, como também auxilia na compreensão e validação da qualidade da evidência sobre o útero em "T". A definição proposta pelo grupo CUME tem o potencial de facilitar o estudo da prevalência, importância clínica e poderá possibilitar análise dos reais benefícios do tratamento cirúrgico nos desfechos reprodutivos. 
É necessário reconhecer se o útero em "T" é realmente uma malformação uterina com consequências clínicas. Até o momento, o seu diagnóstico tem sido subjetivo. O estudo CUME mostrou que, mesmo entre múltiplos especialistas, a concordância do julgamento subjetivo para diagnosticar o útero em "T" não é muito alta, além de ser inviável na prática clínica. Os critérios objetivos propostos pelo estudo CUME poderão ser utilizados em substituição à avalição por múltiplos especialistas para obtenção de resultados semelhantes, o que proporcionaria melhor acurácia e concordância quando se compara ao julgamento subjetivo de um único especialista, como é feito atualmente na prática clínica.

Variações uterinas sutis, como o útero em forma de "T", têm sido apontadas como malformações congênitas, e o tratamento cirúrgico tem sido proposto para melhorar a fertilidade (25). Entretanto, não há evidência suficiente para oferecer tratamento cirúrgico na prática clínica, mesmo para mulheres com antecedentes de desfechos reprodutivos prejudicados, como no aborto de repetição (39). diagnóstico do útero em "T" como anomalia congênita pode ser questionado, podendo ter sido criado por grupos com interesses concorrentes para justificar a indicação de procedimentos cirúrgicos para esta condição (40). A definição proposta pelo ESHRE-ESGE (2) para o útero em "T" não é clara e pode ser mal interpretada, uma vez que o diagnóstico é subjetivo e baseado na impressão do observador. Foi sugerida por especialistas e não foi baseada em evidências científicas (40). Não está claro o que pode ser entendido por cavidade estreita e paredes laterais espessadas por pontos de corte mensuráveis. Por essa definição, não é possível diferenciar o útero em "T" do útero infantil, nem do útero normal. De acordo com a classificação proposta pelo ESHRE-ESGE, aproximadamente $70 \%$ das mulheres apresentarão malformação uterina (17). Os relatos de tratamento cirúrgico para o útero em "T" aumentaram muito após essa classificação, que tem sido apontada como potencial fator iatrogênico, promovendo a identificação de malformações em úteros que seriam, na verdade, normais $(17,36,38)$.

$\mathrm{O}$ tratamento cirúrgico para o útero em " $\mathrm{T}$ " tem revelado os mesmos desafios da conduta para o útero septado. Ressecção histeroscópica para tratamento de septo uterino tem sido realizada há mais de 30 anos a despeito da ausência de evidências de boa qualidade $(41,42)$. A melhor evidência disponível até o momento 
sobre o tema provém de uma coorte retrospectiva multicêntrica, que incluiu 257 mulheres ao longo de 37 anos. Nesse período, os métodos diagnósticos utilizados, como também as definições diagnósticas, variaram. Nos primeiros 20 anos do estudo, o manejo expectante foi amplamente empregado em mulheres com septo pequeno, enquanto intervenção foi realizada em pacientes com deformidades maiores. A alocação das pacientes para ressecção do septo ou manejo expectante foi realizada a critério dos especialistas, de forma subjetiva. Atualmente, existe tendência a oferecer tratamento cirúrgico mesmo para mulheres com septos pequenos. No estudo, 80 dentre 151 mulheres submetidas à metroplastia conseguiram pelo menos um nascido vivo (53\%), comparadas a 76 dentre 106 mulheres submetidas ao manejo expectante (71,7\%) (43), sendo possível concluir que a ressecção uterina não aumenta a taxa de nascido vivo nem diminui taxas de abortamento ou parto pré-termo quando comparada com o manejo expectante. Uma revisão Cochrane (41) não conseguiu identificar ensaios clínicos randomizados que avaliassem o efeito da ressecção histeroscópica do septo nos desfechos reprodutivos. Existe um ensaio clínico randomizado (ECR) recém-concluído, mas ainda não publicado sobre o tema, que levou mais de 10 anos para incluir 68 mulheres (44); a publicação deste estudo trará luz para este tópico, como também para o manejo do útero em "T", condição em que já se afirma o benefício da intervenção antes de se dispor de evidência de boa qualidade.

Antes de expor mulheres a risco e custos desnecessários, ECRs bem desenhados deveriam investigar a eficácia e segurança de uma intervenção (40). Parece pouco provável que um pequeno aumento na cavidade uterina após incisões de poucos milímetros no fundo/endentações laterais seja relevante, quando se considera o diminuto volume de um embrião e o aumento fisiológico do volume da cavidade uterina durante a gravidez (de 1-3 ml para $>4000 \mathrm{ml}$ no final da gestação) (40). Estudos sobre novas intervenções precisam ser lidos com criticidade, uma vez que serão usados como argumento para promover procedimentos que podem ser desnecessários. Há enorme potencial de viés na pesquisa sobre fertilidade, uma vez que tanto a indústria como os pesquisadores estão interessados em provar que as novas técnicas são bem sucedidas (45). 
Uma revisão sistemática recente sobre 0 impacto da metroplastia histeroscópica em mulheres com útero dismórfico com antecedente de abortamento (46) evidenciou que metade das mulheres com histórico de aborto recorrente conseguiu pelo menos um nascido vivo após metroplastia histeroscópica. A classe útero dismórfico (u1), na classificação proposta pelo ESHRE-ESGE (2), inclui dois tipos de útero, além do útero em "T" (u1a): o útero infantil (u1b; cavidade uterina estreita sem paredes laterais espessadas com correlação 1/3 do corpo uterino e 2/3 do colo do útero) e "outros" (u1c; contém todas as deformidades menores da cavidade uterina). Os seis estudos incluídos nesta revisão foram também incluídos na revisão sistemática sobre útero em "T". Entretanto, os mesmos estudos foram julgados como tendo boa qualidade na revisão de útero dismórfico e baixa qualidade na revisão de útero em "T". A revisão sistemática sobre útero dismórfico concluiu que o tratamento cirúrgico é efetivo, ao apresentar taxa de nascido vivo de $50 \%$, de gravidez clínica de $73 \%$ e de abortamento de 23\%. Porém, essas seriam as taxas esperadas sem nenhum tratamento. Ademais, os autores da revisão sobre útero dismórfico realizaram metanálise de estudos retrospectivos sem grupo controle. Os autores enfatizam que não há ECR ou estudos com grupo controle por restrições éticas, e que os resultados por eles encontrados podem indicar a eficácia do tratamento cirúrgico. Entretanto, sem estudos adequados, o real benefício do tratamento do útero em forma de "T" não poderá ser comprovado.

Na revisão sistemática sobre útero em "T", as implicações clínicas do útero em "T" foram avaliadas em estudos observacionais que utilizaram critérios diagnósticos diversos e mal definidos, além de terem descrito técnicas cirúrgicas diferentes. Não foi possível reconhecer o benefício do tratamento cirúrgico para o útero em "T", apesar da descrição de melhora importante dos desfechos reprodutivos.

No estudo CUME para o útero em "T", apesar de ter sido demonstrada concordância moderada no diagnóstico subjetivo entre múltiplos especialistas, a relevância clínica do útero em "T" não relacionado ao DES é desconhecida. As medidas objetivas foram realizadas por observadores muito bem treinados, usando pontos de referência que podem ser difíceis de identificar (como o orifício cervical interno), usando apenas um bloco de US-3D, o que não reflete o que ocorre na 
prática clínica, em que há fontes de variabilidade que podem impactar negativamente a acurácia e confiabilidade do diagnóstico. Nesse estudo, foram selecionadas pacientes que apresentavam endentação lateral subjetiva, o que pode ter sido fonte de viés de seleção. Os resultados do estudo não podem ser generalizados para propósito de rastreio ou para úteros com outras malformações.

Para estudos futuros, existe a necessidade de se aplicarem critérios diagnósticos objetivos e mensuráveis para o útero em "T". As definições propostas pelo estudo CUME poderão auxiliar nisso, além de facilitarem a análise da prevalência do útero em "T" e de sua relevância clínica. Só há, até o momento, estudos que incluíram mulheres com útero em formato de "T" com desfechos reprodutivos prejudicados, e não se sabe, portanto, a relevância desta condição na população geral. Caso estudos futuros confirmem a associação do útero em "T" com desfechos reprodutivos ruins, ensaios clínicos randomizados com grupo controle de pacientes em manejo expectante devem ser realizados para avaliar os benefícios da metroplastia histeroscópica nos resultados reprodutivos. Até o momento, não há evidências suficientes para apontar o útero em "T" como uma malformação uterina, mas como uma variante do útero normal, a fim de evitar intervenções desnecessárias sem que haja comprovação dos reais benefícios. 
5. Conclusões 
A concordância entre múltiplos especialistas é apenas moderada para o diagnóstico do útero em "T". Três medidas com boa acurácia diagnóstica e razoável a moderada confiabilidade foram propostas para o útero em "T": profundidade da endentação lateral $\geq 7 \mathrm{~mm}$, ângulo de endentação lateral $\leq 130^{\circ}$ e ângulo "T" $\leq 40^{\circ}$. Até o momento, não se sabe a prevalência, as possíveis etiologias e a relevância clínica do útero em "T", uma vez que os estudos disponíveis não utilizaram critérios diagnósticos objetivos para a análise dessa condição. Pouco se sabe sobre os benefícios da metroplastia histeroscópica no tratamento do útero em "T", uma vez que não há ensaios clínicos randomizados que incluam grupo controle. A definição proposta pelo grupo CUME para o útero em "T", baseada em critérios objetivos mensuráveis, poderá auxiliar no desenvolvimento de estudos futuros sobre o útero em formato de "T". 


\section{Referências Bibliográficas ${ }^{1}$}

\footnotetext{
${ }^{1}{ }^{1}$ Elaboradas de acordo com as Diretrizes para Apresentação de Dissertações e Teses da USP: Documento Eletrônico e Impresso - Parte IV (Vancouver) 3를 ed. São Paulo: SIBi/USP, 2016.
} 
1. Acien $\mathrm{P}$, Acien $\mathrm{M}$. The presentation and management of complex female genital malformations. Hum Reprod Update. 2016;22(1):48-69.

2. Grimbizis GF et al. The ESHRE/ESGE consensus on the classification of female genital tract congenital anomalies. Human Reprod (Oxford, England). 2013;28(8):2032-44.

3. Fernandez $\mathrm{H}$ et al. Surgical approach to and reproductive outcome after surgical correction of a T-shaped uterus. Human Reprod (Oxford, England). $2011 ; 26(7): 1730-4$.

4. Kaufman $\mathrm{RH}$ et al. Upper genital tract changes associated with exposure in utero to diethylstilbestrol. Obstetrical \& gynecological survey. 1977;32(7):611-3.

5. Buttram Jr VC, Gibbons WE. Müllerian anomalies: a proposed classification. (An analysis of 144 cases). Fertil Steril. 1979;32(1):40-6.

6. The American Fertility Society. The American Fertility Society classifications of adnexal adhesions, distal tubal occlusion, tubal occlusion secondary to tubal ligation, tubal pregnancies, mullerian anomalies and intrauterine adhesions. Fertil Steril. 1988;49(6):944-55.

7. Grimbizis GF et al. The Thessaloniki ESHRE/ESGE consensus on diagnosis of female genital anomalies. Gynecol Surg. 2016;13:1-16.

8. Bermejo $\mathrm{C}$ et al. Three-dimensional ultrasound in the diagnosis of Müllerian duct anomalies and concordance with magnetic resonance imaging. Ultrasound Obstet Gynecol. 2010;35(5):593-601.

9. Graupera B et al. Accuracy of three-dimensional ultrasound compared with magnetic resonance imaging in diagnosis of Mullerian duct anomalies using ESHRE-ESGE consensus on the classification of congenital anomalies of the female genital tract. Ultrasound Obstet Gynecol. 2015;46(5):616-22.

10. Saravelos $\mathrm{SH}$ et al. Assessment of the uterus with three-dimensional ultrasound in women undergoing ART. Hum Reprod Update. 2017;23(2):188-210.

11. Practice Committee of the American Society for Reproductive Medicine. Uterine septum: a guideline. Fertil Steril. 2016;106(3):530-40.

12. Ludwin A et al. Congenital Uterine Malformation by Experts (CUME): better criteria for distinguishing between normal/arcuate and septate uterus. Ultrasound Obstet Gynecol. 2018;51(1):101-9.

13. Şükür YE et al. Hysteroscopic corrections for complete septate and T-Shaped uteri have similar surgical and reproductive outcome. Reprod Sci. 2018;25(12):1649-54. 
14. Epelboin S. Diethylstilbestrol exposure in utero. Polemics about metroplasty. The cons. Gynecol Obstet Fertil. 2007;35(9):832-41.

15. Al Jishi T, Sergi C. Current perspective of diethylstilbestrol (DES) exposure in mothers and offspring. Reprod Toxicol. 2017;71:71-7.

16. van Gils AP et al. Abnormalities of the uterus and cervix after diethylstilbestrol exposure: correlation of findings on MR and hysterosalpingography. Am $\mathrm{J}$ Roentgenol. 1989;153(6):1235-8.

17. Ludwin A, Ludwin I. Comparison of the ESHRE-ESGE and ASRM classifications of Mullerian duct anomalies in everyday practice. Human Reprod. 2015;30(3):569-80.

18. Di Spiezio Sardo A et al. Hysteroscopic outpatient metroplasty to expand dysmorphic uteri (HOME-DU technique): a pilot study. Reprod Biomed Online. 2015;30(2):166-74.

19. Ducellier-Azzola G et al. Hysteroscopic enlargement metroplasty for T-shaped uterus: 24 years' experience at the Strasbourg Medico-Surgical and Obstetrical Centre (CMCO). Eur J Obstet Gynecol Reprod Biol. 2018;226:30-4.

20. Neal SA et al. Three-dimensional ultrasound diagnosis of T-shaped uterus is associated with adverse pregnancy outcomes after embryo transfer. Reprod Biomed Online. 2019;39(5):777-83.

21. Boza A et al. Surgical correction of T-shaped uteri in women with reproductive failure: Long term anatomical and reproductive outcomes. J Gynecol Obstet Hum Reprod. 2019;48(1):39-44.

22. Puente JM et al. Adenomyosis in infertile women: prevalence and the role of 3D ultrasound as a marker of severity of the disease. Reprod Biol Endocrinol. 2016;14(1):60.

23. Saravelos SH, Cocksedge KA, Li T-C. Prevalence and diagnosis of congenital uterine anomalies in women with reproductive failure: a critical appraisal. Hum Reprod Update. 2008;14(5):415-29.

24. Chan $Y Y$ et al. The prevalence of congenital uterine anomalies in unselected and high-risk populations: a systematic review. Hum Reprod Update. 2011;17(6):76171.

25. Ludwin A, Lindheim SR. T-shaped uterus and subtle uterine variances: a need for reliable criteria. Fertil Steril. 2019;112(2):248-9.

26. Di Spiezio Sardo A et al. Long-term reproductive outcomes after hysteroscopic treatment of dysmorphic uteri in women with reproductive failure: An European Multicenter Study. J Minim Invasive Gynecol. 2020;27(3):755-62. 
27. Pacheco LA et al. Hysteroscopic outpatient metroplasty for T-shaped uterus in women with reproductive failure: Results from a large prospective cohort study. Eur J Obstet Gynecol Reprod Biol. 2019;243:173-8.

28. Uyar $\mathrm{E}$ et al. IVF outcomes after hysteroscopic metroplasty in patients with Tshaped uterus. Fertil Res Pract. 2019;5:15.

29. Haydardedeoğlu B et al. Reproductive outcomes of office hysteroscopic metroplasty in women with unexplained infertility with dysmorphic uterus. Turk $\mathrm{J}$ Obstet Gynecol. 2018;15(3):135-40.

30. Fox NS et al. Type of congenital uterine anomaly and adverse pregnancy outcomes. J Matern Fetal Neonatal Med. 2014;27(9):949-53.

31. Ferro $\mathrm{J}$ et al. Reproductive outcomes after hysteroscopic metroplasty for women with dysmorphic uterus and recurrent implantation failure. Facts Views Vis Obgyn. 2018;10(2):63-8.

32. Barranger $\mathrm{E}$ et al. Reproductive performance after hysteroscopic metroplasty in the hypoplastic uterus: a study of 29 cases. BJOG. 2002;109(12):1331-4.

33. Garbin $\mathrm{O}$ et al. Hysteroscopic metroplasty in diethylstilboestrol-exposed and hypoplastic uterus: a report on 24 cases. Human Reprod. 1998;13(10):2751-5.

34. Giacomucci E et al. Term delivery rate after hysteroscopic metroplasty in patients with recurrent spontaneous abortion and T-shaped, arcuate and septate uterus. Gynecol Obstet Invest. 2011;71(3):183-8.

35. Katz $Z$ et al. Beneficial effect of hysteroscopic metroplasty on the reproductive outcome in a 'T-shaped' uterus. Gynecol Obstet Invest. 1996;41(1):41-3.

36. Knez $\mathrm{J}$ et al. ESHRE/ESGE female genital tract anomalies classification systemthe potential impact of discarding arcuate uterus on clinical practice. Hum Reprod. 2018;33(4):600-6.

37. Ludwin A et al. Reliability of the European Society of Human Reproduction and Embryology/European Society for Gynaecological Endoscopy and American Society for Reproductive Medicine classification systems for congenital uterine anomalies detected using three-dimensional ultrasonography. Fertil Steril. 2015;104(3):688-97 e8.

38. Prior $\mathrm{M}$ et al. Outcome of assisted reproduction in women with congenital uterine anomalies: a prospective observational study. Ultrasound Obstet Gynecol. 2018;51(1):110-7.

39. ESHRE Guideline Group on RPL et al. ESHRE guideline: recurrent pregnancy loss. Hum Reprod Open. 2018;2018(2):hoy004. 
40. Ludwin A, Martins WP. Uterine 'anomalies' by ESHRE/ESGE classification: are more than half of the women really sick? Ultrasound Obstet Gynecol. 2020 Jan 28. doi: 10.1002/uog.21986. Online ahead of print.

41. Rikken JFet al. Septum resection for women of reproductive age with a septate uterus. Cochrane Database Syst Rev. 2017;1(1):CD008576.

42. Spanish Infertility SG et al. Hysteroscopic septum resection and reproductive medicine: A SWOT analysis. Reprod Biomed Online. 2018;37(6):709-15.

43. Rikken JFW et al. Corrigendum. Septum resection in women with a septate uterus: a cohort study. Hum Reprod. 2020 May 30;deaa141. doi: 10.1093/humrep/deaa141. Online ahead of print.

44. Rikken JFW et al. The randomised uterine septum transsection trial (TRUST): design and protocol. BMC Womens Health. 2018;18(1):16

45. Ludwin A, Neto MC, Martins WP. Regarding long-term reproductive outcomes after hysteroscopic treatment of dysmorphic uteri in women with reproductive failure: An European Multicenter Study. J Minim Invasive Gynecol. 2020;27(3):781-2.

46. De Franciscis $P$ et al. Impact of hysteroscopic metroplasty on reproductive outcomes of women with a dysmorphic uterus and recurrent miscarriages: a systematic review and meta-analysis. J Gynecol Obstet Hum Reprod. 2020:101763. 
7. Anexos 


\section{ANEXO A - AUTORIZAÇÃo DA REVISTA PARA PUBLICAÇÃO DO ARTIGO "Congenital Uterine Malformation by Experts (CUME): T-shaped uterus"}

JOHN WILEY AND SONS LICENSE

TERMS AND CONDITIONS

May 30, 2020 This Agreement between av pedro felicio cavalcante, 3030, casa 16 ("You") and John Wiley
and Sons ("John Wiley and Sons") consists of your license details and the terms and conditions provided by John Wiley and Sons and Copyright Clearance Center.

License Number

4838781473758

License date

May 30, 2020

Licensed Content

Publisher

John Wiley and Sons

Licensed Content Publication

ULTRASOUND IN OBSTETRICS and GYNECOLOGY

Licensed Content Title

Congenital Uterine Malformation by Experts (CUME): diagnostic criteria for T-shaped uterus

Licensed Content Author

A. Ludwin, M. A. Coelho Neto, I. Ludwin, et al

Licensed Content

Date

May 15, 2020

Licensed Content

Volume

0

Licensed Content Issue

0

Licensed Content Pages 
- The materials you have requested permission to reproduce or reuse (the "Wiley Materials") are protected by copyright.

- You are hereby granted a personal, non-exclusive, non-sub licensable (on a standalone basis), non-transferable, worldwide, limited license to reproduce the Wiley. Materials for the purpose specified in the licensing.process. This license, and any CONTENT (PDF or image file) purchased as part of your order, is for a one-time use only and limited to any maximum distribution number specified in the license. The first instance of republication or reuse granted by this license must be completed within two years of the date of the grant of this license (although copies prepared before the end date may be distributed thereafter). The Wiley Materials shall not be used in any other manner or for any other purpose, beyond what is granted in the license. Permission is granted subject to an appropriate acknowledgement given to the author, title of the material/book/journal and the publisher. You shall also duplicate the copyright notice that appears in the Wiley publication in your use of the Wiley Material. Permission is also granted on the understanding that nowhere in the text is a previously published source acknowledged for all or part of this Wiley Material. Any third party content is expressly excluded from this permission.

- With respect to the Wiley Materials, all rights are reserved. Except as expressly granted by the terms of the license, no part of the Wiley Materials may be copied, modified, adapted (except for minor reformatting required by the new Publication), translated, reproduced, transferred or distributed, in any form or by any means, and no derivative works may be made based on the Wiley Materials without the prior permission of the respective copyright owner.For STM Signatory Publishers clearing permission under the terms of the STM Permissions Guidelines only, the terms of the license are extended to include subsequent editions and for editions in other languages, provided such editions are for the work as a whole in situ and does not involve the separate exploitation of the permitted figures or extracts, You may not alter, remove or suppress in any manner any copyright, trademark or other notices displayed by the Wiley Materials. You may not license, rent, sell, loan, lease, pledge, offer as security, transfer or assign the Wiley Materials on a stand-alone basis, or any of the rights granted to you hereunder to any other person.

- The Wiley Materials and all of the intellectual property rights therein shall at all times remain the exclusive property of John Wiley \& Sons Inc, the Wiley Companies, or their respective licensors, and your interest therein is only that of having possession of and the right to reproduce the Wiley Materials pursuant to Section 2 herein during the continuance of this Agreement. You agree that you own no right, title or interest in or to the Wiley Materials or any of the intellectual property rights therein. You shall have no rights hereunder other than the license as provided for above in Section 2. No right, license or interest to any trademark, trade name, service mark or other branding ("Marks") of WILEY or its licensors is granted hereunder, and you agree that you shall not assert any such right, license or interest with respect thereto

- NEITHER WILEY NOR ITS LICENSORS MAKES ANY WARRANTY OR REPRESENTATION OF ANY KIND TO YOU OR ANY THIRD PARTY, EXPRESS, IMPLIED OR STATUTORY, WITH RESPECT TO THE MATERIALS OR THE ACCURACY OF ANY INFORMATION CONTAINED IN THE MATERIALS, INCLUDING, WITHOUT LIMITATION, ANY IMPLIED WARRANTY OF MERCHANTABILITY, ACCURACY, SATISFACTORY QUALITY, FITNESS FOR A PARTICULAR PURPOSE, USABILITY, INTEGRATION OR NON-INFRINGEMENT AND ALL SUCH WARRANTIES ARE HEREBY EXCLUDED BY WILEY AND ITS LICENSORS AND WAIVED BY YOU.

- WILEY shall have the right to terminate this Agreement immediately upon breach of this Agreement by you. 
- You shall indemnify, defend and hold harmless WILEY, its Licensors and their respective directors, officers, agents and employees, from and against any actual or threatened claims, demands, causes of action or proceedings arising from any breach of this Agreement by you.

- IN NO EVENT SHALL WILEY OR ITS LICENSORS BE LIABLE TO YOU OR ANY OTHER PARTY OR ANY OTHER PERSON OR ENTITY FOR ANY SPECIAL, CONSEQUENTIAL, INCIDENTAL, INDIRECT, EXEMPLARY OR PUNITIVE DAMAGES, HOWEVER CAUSED, ARISING OUT OF OR IN CONNECTION WITH THE DOWNLOADING, PROVISIONING, VIEWING OR USE OF THE MATERIALS REGARDLESS OF THE FORM OF ACTION, WHETHER FOR BREACH OF CONTRACT, BREACH OF WARRANTY, TORT, NEGLIGENCE, INFRINGEMENT OR OTHERWISE (INCLUDING, WITHOUT LIMITATION, DAMAGES BASED ON LOSS OF PROFITS, DATA, FILES, USE, BUSINESS OPPORTUNITY OR CLAIMS OF THIRD PARTIES), AND WHETHER OR NOT THE PARTY HAS BEEN ADVISED OF THE POSSIBILITY OF SUCH DAMAGES. THIS LIMITATION SHALL APPLY NOTWITHSTANDING ANY FAILURE OF ESSENTIAL PURPOSE OF ANY LIMITED REMEDY PROVIDED HEREIN.

- Should any provision of this Agreement be held by a court of competent jurisdiction to be illegal, invalid, or unenforceable, that provision shall be deemed amended to achieve as nearly as possible the same economic effect as the original provision, and the legality, validity and enforceability of the remaining provisions of this Agreement shall not be affected or impaired thereby.

- The failure of either party to enforce any term or condition of this Agreement shall not constitute a waiver of either party's right to enforce each and every term and condition of this Agreement. No breach under this agreement shall be deemed waived or excused by either party unless such waiver or consent is in writing signed by the party granting such waiver or consent. The waiver by or consent of a party to a breach of any provision of this Agreement shall not operate or be construed as a waiver of or consent to any other or subsequent breach by such other party.

- This Agreement may not be assigned (including by operation of law or otherwise) by you without WILEY's prior written consent.

- Any fee required for this permission shall be non-refundable after thirty (30) days from receipt by the CCC.

- These terms and conditions together with CCC's Billing and Payment terms and conditions (which are incorporated herein) form the entire agreement between you and WILEY concerning this licensing transaction and (in the absence of fraud) supersedes all prior agreements and representations of the parties, oral or written. This Agreement may not be amended except in writing signed by both parties. This Agreement shall be binding upon and inure to the benefit of the parties' successors, legal representatives, and authorized assigns.

- In the event of any conflict between your obligations established by these terms and conditions and those established by CCC's Billing and Payment terms and conditions, these terms and conditions shall prevail.

- WILEY expressly reserves all rights not specifically granted in the combination of (i) the license details provided by you and accepted in the course of this licensing transaction, (ii) these terms and conditions and (iii) CCC's Billing and Payment terms and conditions. 
- This Agreement will be void if the Type of Use, Format, Circulation, or Requestor Type was misrepresented during the licensing process.

- This Agreement shall be governed by and construed in accordance with the laws of the State of New York, USA, without regards to such state's conflict of law rules. Any legal action, suit or proceeding arising out of or relating to these Terms and Conditions or the breach thereof shall be instituted in a court of competent jurisdiction in New York County in the State of New York in the United States of America and each party hereby consents and submits to the personal jurisdiction of such court, waives any objection to venue in such court and consents to service of process by registered or certified mail, return receipt requested, at the last known address of such party.

\section{WILEY OPEN ACCESS TERMS AND CONDITIONS}

Wiley Publishes Open Access Articles in fully Open Access Journals and in Subscription journals offering Online Open. Although most of the fully Open Access journals publish open access articles under the terms of the Creative Commons Attribution (CC BY) License only, the subscription journals and a few of the Open Access Journals offer a choice of Creative Commons Licenses. The license type is clearly identified on the article.

\section{The Creative Commons Attribution License}

The Creative Commons Attribution License (CC-BY) allows users to copy, distribute and transmit an article, adapt the article and make commercial use of the article. The CC-BY license permits commercial and non-

\section{Creative Commons Attribution Non-Commercial License}

The Creative Commons Attribution Non-Commercial (CC-BY-NC)License permits use, distribution and reproduction in any medium, provided the original work is properly cited and is not used for commercial purposes.(see below)

\section{Creative Commons Attribution-Non-Commercial-NoDerivs License}

The Creative Commons Attribution Non-Commercial-NoDerivs License (CC-BY-NC-ND) permits use, distribution and reproduction in any medium, provided the original work is properly cited, is not used for commercial purposes and no modifications or adaptations are made. (see below)

\section{Use by commercial "for-profit" organizations}

Use of Wiley Open Access articles for commercial, promotional, or marketing purposes requires further explicit permission from Wiley and will be subject to a fee.

Further details can be found on Wiley Online Library

http://olabout.wiley.com/WileyCDA/Section/id-410895.html

\section{Other Terms and Conditions:}

\section{v1.10 Last updated September 2015}

Questions? customercare@ㅇpyright.com or +1-855-239-3415 (toll free in the US) or 
+1-978-646-2777. 


\section{ANEXO B - COMPROVANTE DE SUBMISSÃo do ARTIGo "Definitions, prevalence, clinical implications and treatment of $t$-shaped uterus: systematic review"}

30-Apr-2020

Manuscript number: UOG-2020-0491

Dear Dr Coelho Neto

We are pleased to receive your manuscript entitled Definitions, prevalence, clinical implications and treatment of T-shaped uterus: systematic review by Coelho Neto, Marcela; Ludwin, Artur; Petraglia, Felice; Martins, Wellington. We will shortly be assigning it to one of the Journal's Editors who will handle the peer review of the paper.

To track the progress of your manuscript through the editorial process using our web-based system, simply point your browser to:

https://eur05.safelinks.protection.outlook.com/?url=https\%3A\%2F\%2Fmc.manuscriptcentral.com\%2Fu og\&amp;data=02\%7C01\%7C\%7C1f3809e757d74586bf5008d7eceebd44\%7C84df9e7fe9f640afb435aaa aaaaaaaa\%7C1\%7C0\%7C637238382424992074\&amp;sdata=NvlQSbCbkIV8LvjTDdeVS4W5HvFUn2dy gAHdrJfN4ck\%3D\&amp;reserved $=0$

and log in using the following user ID and password:

(User ID):

(Password): https://eur05.safelinks.protection.outlook.com/?url=https\%3A\%2F\%2Fmc.manuscriptcentra I.com\%2Fuog\%3FURL MASK\%3D8941523438ca44a8bd9e70613d6c74f6\&amp;data=02\%7C01\%7C\%7C 1f3809e757d74586bf5008d7eceebd44\%7C84df9e7fe9f640afb435aaaaaaaaaaaa\%7C1\%7C0\%7C637238 382424992074\&amp;sdata=xEXTVaFCoCn9yzhPxfOevMAGIDREV7NXNKWikxhggCl\%3D\&amp;reserve $\underline{\mathrm{d}=0}$

Please remember in any future correspondence regarding this article to always include its manuscript ID number UOG-2020-0491.

Many thanks for submitting your manuscript

Yours sincerely

Sarah Hatcher

Managing Editor 


\section{ANEXO C - DISPENSA DE ANÁLISE PELO CEP}

Ribeirão Preto, 15/10/2018

À coordenação do Comitê de Ética em Pesquisa do HCRP e FRMP - USP

Cara Professora Dra. Márcia Guimarães Villanova,

Venho, através desta, solicitar dispensa de análise pelo Comitê de Ética em Pesquisa para o projeto intitulado "Congenital Uterine Malformations by Experts (CUME): what is Tshaped uterus?" (Malformações congênitas do útero por especialistas - (CUME): o que é útero em “ $T$ "?), a ser desenvolvido no Departamento de Ginecologia e Obstetrícia (DGO) do HCRP. A pesquisadora responsável pelo estudo é Marcela de Alencar Coelho Neto, aluna de doutorado do DGO. O orientador do estudo é o professor Wellington de Paula Martins.

O estudo foi aprovado pelo DGO, mas foi solicitado que o mesmo deve ser envid fơ fó Comitê de Ética em Pesquisa do Hospital das Clínicas de Ribeirão Preto para análise, anntês do início de sua execução.

O estudo em questão se trata de um estudo em conjunto com outra instituiçăa $\bar{C}$ R $P$ (Universidade Jagiellonian, Cracóvia, Polônia), cujo comitê de ética já aprovou sua realização. 0 pesquisador participante da referida instituição se chama Artur Ludwin (citado no projeto de pesquisa como pesquisador envolvido).

Estamos fazendo tal solicitação porque os pesquisadores brasileiros não terão contato com as pacientes do estudo, nem com prontuários. A pesquisa será realizada através da análise de blocos de ultrassonografia 3D anônimos, previamente colhidos e armazenados pelos pesquisadores da Polônia e enviados para os pesquisadores brasileiros via nuvem (arquivos salvos no Dropbox). Todas as pacientes do estudo são da Polônia e assinaram termo de consentimento para participarem do estudo.

A realização do estudo não implicará em custos para a Faculdade de Medicina de Ribeirão Preto, uma vez que os exames de ultrassonografia foram realizados em outra instituição, e os dados serão analisados nos computadores dos próprios pesquisadores. A análise estatística e redação do estudo também serão realizadas pelos autores do estudo. Não será solicitado nenhum financiamento para sua execução.

Atenciosamente,

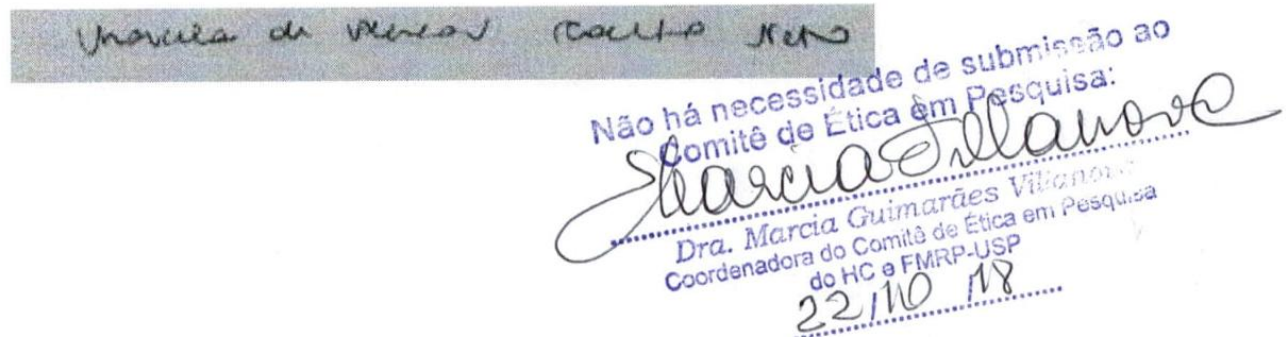


Marcela de Alencar Coelho Neto

Aluna de doutorado do DGO

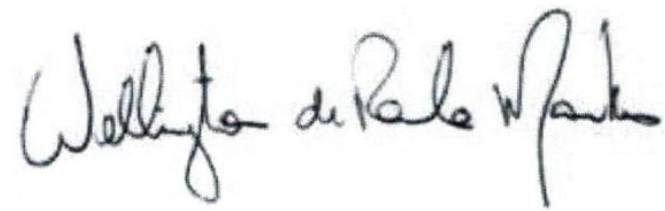

Wellington de Paula Martins

Orientador 


\section{UNIVERSIDADE DE SÃO PAULO}

\section{FACULDADE DE MEDICINA DE RIBEIRÃO PRETO}

\section{PROJETO DE PESQUISA}

Malformações congênitas do útero por especialistas (Congenital Uterine Malformation by Experts-CUME): o que é útero em "T"?

\section{LINHA DE PESQUISA}

Mecanismos envolvidos na foliculogênese e determinantes da qualidade oocitária/embrionária e da interação gamética, o ambiente intrafolicular e endometrial relacionados à fertilidade.

\section{NUCLEO DE PESQUISA OU SETOR}

Setor de Reprodução Humana do Departamento de Ginecologia e Obstetrícia da Faculdade de Medicina de Ribeirão Preto, USP, Ribeirão Preto, SP.

\section{LOCAL DE EXECUÇÃO}

Setor de Reprodução Humana do Hospital das Clínicas da FMRP-USP, Ribeirão Preto, São Paulo.

Jagiellonian University, Krakow, Poland.

PESQUISADOR RESPONSÁVEL

Wellington P. Martins

\section{PESQUISADORES ENVOLVIDOS}

Marcela A. C. Neto; Artur Ludwin; Wellington P. Martins.

PERIÓDICO-ALVO

Fertility and Sterility

Ultrasound in Obstetrics and Gynecology
QUALIS

A1

A1 


\section{Ribeirão Preto 2018}

Abstract

Introduction: T-shaped uterus is a uterine malformation characterizes by the presence of lateral indentation, with a severe narrowing of the uterine cavity from the lateral sides, what makes the shaped of the endometrial cavity resembles a " $T$ " instead of a triangle. T-shaped uterus is commonly related to in uterus exposure to Diethylstilbestrol (DES), a medication using until 1980's to prevent miscarriage, but it can also be related to Asherman syndrome or pelvic tuberculosis besides the possibility of having no etiology identified. There is no consensus on the gold standard ultrasound technique for diagnosing T-shaped uteri and no strict parameters for its definition.

Objective: This study aims to analyze previously recorded 3D ultrasound datasets containing images from the uterus subjectively classified as being T-shaped uterus or not by experts, to develop possible measurements that may be used to establish objective diagnostic criteria for T-shaped uterus considering reproducibility and accuracy of the measurements between observers.

Methods: Observational prospective study to evaluate reproducibility, agreement, diagnostic accuracy and elaboration of an algorithm to differentiate T-shaped uterus from normal uterus. The patients of the study will be evaluated in the Jagiellonian University, Krakow, Poland. The 3D-US datasets will be sent to the other researchers. To achieve a consensus in differentiating T-shaped uterus from normal uterus, images originated from 3D-datasets will be sent to fifteen experts in the field of ultrasound, gynecology and gynecologic surgeries who will perform subjective judgements (each patient will be classified as having Tshaped uterus $r$ normal uterus). Two expert observers (WPM and AL) will perform some measurements in the uteri, using 3D datasets previously recorded, to draw an algorithm to diagnose T-shaped uterus. Then, the reproducibility and the accuracy of these measurements will be estimated by CCC. The agreement between 
the two observers regarding the measurements made will be evaluated by Cohen's kappa and weighted Cohen's Kappa.

Key words: Mullerian ducts, Congenital Uterine Anomalies, T-shaped uterus, Dysmorphic uterus Agreement 
Resumo

Introdução: Útero em "T" é uma malformação uterina caracterizada pela presença de endentação lateral, com um severo estreitamento da cavidade uterina nas laterais, o que faz o formato da cavidade endometrial lembra um "T" em vez de um triângulo. Útero em " $\mathrm{T}$ " é comumente associado à exposição ao dietilestilbestrol (DES), uma medicação usada até a década de 80 para prevenir abortamento, mas também pode estar relacionado à síndrome de Asherman ou à tuberculose pélvica, além da possibilidade de não ter etiologia identificada. Não existe consenso em relação à técnica padrão-ouro para diagnóstico do útero em "T" e nem parâmetros estritos para sua definição.

Objetivo: Este estudo tem como objetivo analisar blocos de dados de ultrassonografia 3D (US-3D) previamente gravados contendo imagens de úteros subjetivamente classificados como sendo útero em " $\mathrm{T}$ " ou não por especialistas, a fim de desenvolver possíveis medidas que possam ser usadas para estabelecer critérios diagnósticos objetivos para útero em " $\mathrm{T}$ " considerando a reprodutibilidade e acurácia das medidas entre observadores.

Métodos: Estudo prospectivo observacional para avaliar reprodutibilidade, concordância, acurácia diagnóstica e elaboração de um algoritmo para diferenciar útero em "T" de útero normal. As pacientes do estudo serão avaliadas na Universidade Jagiellonian, na Cracóvia, Polônia. Os blocos de dados de US-3D serão enviados para os outros pesquisadores. Para alcançar um consenso em diferenciar útero em "T" de útero normal, imagens oriundas dos blocos de US-3D serão enviadas para quinze especialistas no campo da ultrassonografia, ginecologia, cirurgia ginecológica, que irão julgá-las subjetivamente (cada paciente será classificada como tendo útero em " $\mathrm{T}$ " ou útero normal). Dois especialistas irão realizar algumas medidas no útero, usando os blocos de US-3D previamente gravados, para desenvolver um algoritmo para diagnosticar útero em "T". A seguir, a reprodutibilidade e acurácia destas medidas será estimada pelo CC (coeficiente de correlação de concordância. A concordância entre os dois observadores em relação às medidas feitas será avaliada pelo Cohen kappa e pelo Cohen kappa ponderado.

Key words: ductos Mullerianos, Malformações uterinas congênitas, útero em " $T$ ", concordância do útero dismórfico. 